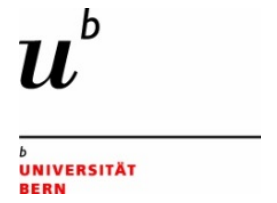

\title{
Vietnam's recognition and enforcement of foreign arbitral awards and preparation for EVFTA
}

\author{
Nguyen Phuong Linh \\ Foreign Trade University (FTU), Vietnam \\ phuonglinh@ftu.edu.vn
}

\section{Dinh Hoang Anh}

Foreign Trade University (FTU), Vietnam

dinhhoanganh@ftu.edu.vn

\section{Chu Thanh Giang \\ Central Economic Commission, Vietnam \\ chugiangbkt@gmail.com}

Abstract: Arbitration activities in Vietnam is becoming a popular choice of investors in dispute resolution. However, European investors in Vietnam repeatedly raised concerns that it is extremely difficult in practice to achieve the recognition and enforcement of foreign arbitral awards through the Vietnamese courts. Now the European - Vietnam Free Trade Agreement (EVFTA) which is expected to take effect in 2018 has imposed a new two-tier investment court system (ICS) for investors-States dispute settlement (ISDS) instead of traditional arbitration-based ISDS. This paper focuses on analysing the compatibility between the ICS mechanism and Vietnam legal framework and current practice in recognition and enforcement of foreign arbitral awards, thereby proposing some recommendations for Vietnam's preparation with the EVFTA ahead.

Keywords: EVFTA, ISDS, investment court, ICS, Vietnam.

Research for this paper was funded by the Swiss State Secretariat for Economic Affairs under the SECO / WTI Academic Cooperation Project, based at the World Trade Institute of the University of Bern, Switzerland.

SECO working papers are preliminary documents posted on the WTI website (WWW.Wti.Org) and widely circulated to stimulate discussion and critical comment. These papers have not been formally edited. Citations should refer to a "SECO / WTI Academic Cooperation Project" paper with appropriate reference made to the author(s). 


\section{Vietnam's recognition and enforcement of foreign arbitral awards and preparation for EVFTA}

Nguyen Phuong Linh, Dinh Hoang Anh, Chu Thanh Giang

\section{Part 1. Investor-State dispute settlement mechanisms}

The history of investor - State dispute settlement can be traced back from the development history of the treatment of foreign investors and their property under international law. In early history of trade, foreign investors were often considered 'outsiders' and received less treatment than nationals of the country they were making investment in ${ }^{1}$; however, overtime, due to the increase of trade and investment, and under the pressure of international law, the interests of foreign investors are more protected. Since the aftermath of the World War II period, the network of International Investment Agreements (IIAs) supplemented by the general rules of international laws started to replace the limited diplomatic protection and provide investors dynamic treaty-based standards of investment promotion and protection ${ }^{2}$. More specifically, a foreign investor, in case of a mistreatment from the host State that caused injury to their investment, may make a claim directly against the host State pursuant to the standards provided by the treaties, and they would be a part of the arbitration proceedings, instead of relying on the diplomatic protection as before. This investor-state arbitration mechanism, or so called the investor-state dispute settlement is included in the large majority of today IIAs which are largely conformed by bilateral investment treaties (BITs) and free trade agreements

\footnotetext{
${ }^{1}$ Andrew Newcombe, Lluis Paradell, 2009, 'Law and Practice of Investment Treaties: Standards of Treatment', Kluwer Law International BV, The Netherlands Publisher.

${ }^{2}$ Ibid
} 
(FTAs) with investment chapters. The ISDS mechanism is also a fundamental instrument of States to uphold the compliance of commitments that they have made in the IIAs ${ }^{3}$.

When we talk about ISDS or international arbitration institutions, some fora cannot be neglected. This first part of the paper will look at some prominent fora and arbitral rules from which we can see the importance of arbitration in modern world trade and investment.

\section{ICSID (International Centre for Settlement of Investment Disputes)}

As a result of the Convention on the Settlement of Investment Disputes between States and Nationals of Other States, the ICSID has been established in 1965 as an international arbitration institution, serving as a platform for international investment dispute resolution. As stated in its mandate, the purpose of the ICSID is "to provide facilities for conciliation and arbitration of investment disputes between Contracting States and nationals of other contracting States".

Jurisdiction: The jurisdiction of ICSID is over any "legal dispute arising directly out of an investment". There are two sets of procedural rules that the Centre mostly often governs and conduct the arbitration with, which are the ICSID Convention, Regulations and Rules, and the ICSID Additional Facility Rules. While ICSID Convention is for arbitration proceedings for a legal dispute between a party state of the convention and a national of another ICSID Contracting State, the Additional Facility serves to support non-party investors or hosts. As the nature of arbitration is based on the willingness of both parties to resolve conflicts, the given consent from both parties for ICSID jurisdiction is critical aspect of arbitrators' authority to hear the claimss.

\footnotetext{
${ }^{3}$ OECD, 'Investor-State Dispute Settlement - Public Consultation: 16 May - 9 July 2012'

${ }^{4}$ Article 25(1) of ICSID Convention

${ }^{5}$ Ibid.
} 
Choice of arbitrators: The decision on the appointment of the members of the tribunal can be made upon agreement between two parties. Most tribunals are composed of three arbitrators. If no agreement can be reached, the Chairman of Administrative Council will appoint. ${ }^{6}$

\section{Proceedings:}

Figure 1.1 Proceedings of ICSID

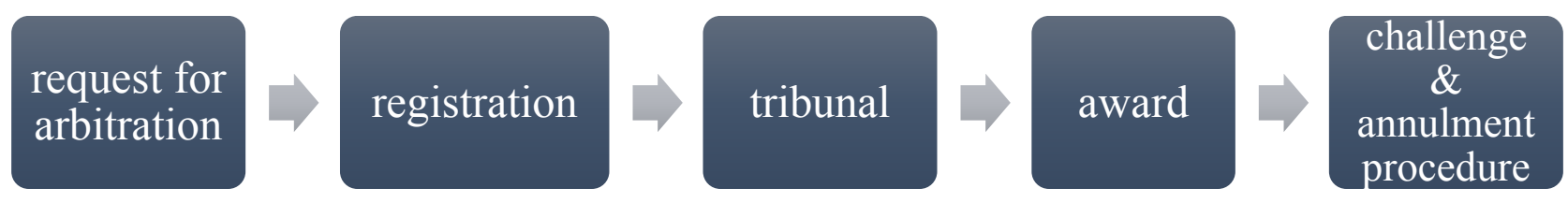

Firstly, a submission of Request for Arbitration is needed to initiate the ICSID arbitration. The request is submitted to the Secretary - General, attached with a description of the facts and legal issues. This stage is to determine whether the claim was "manifestly outside the jurisdiction of" the ICSID Convention. Otherwise, the proceedings shall begin.

Afterwards, an arbitral tribunal is constituted to deal with preliminary consultations and adversarial proceedings. The adversarial proceedings include two phases of a written procedure and oral arguments, as a chance for in- person hearings and two parties can present their legal arguments, evidence, response, etc. Eventually, the tribunal deliberates and renders its award.

Applicable law: The choice of law is left to the parties upon their agreement. In the absence of such agreement, the Tribunal shall apply the law of the Contracting State party to the dispute (including its rules on the conflict of laws) and such rules of international law as may be applicable". ${ }^{7}$ Thus, it would be the combination of international law and host State law and international law often prevail.

\footnotetext{
${ }^{6}$ Articles 37 and 38 of ICSID Convention

${ }^{7}$ Article 42.1 ICSID Convention
} 
Awards and enforcement: ICSID Arbitral tribunal decisions are to be final and not subject to any appeal. This is different to WTO dispute settlement mechanism. If a party disagrees with an ICSID award, they can seek the postaward remedies from an ad hoc annulment committee. There is a thing should be bear in mind is that this stage is not to challenge the award on the basis of its enforcement. An award may be annulled only in case of malfunctions of the Tribunal; or procedural breach; or failure to state the reason on which the award is based ${ }^{8}$. An award is 'annulled' means it is "lifted", set aside either partly or completely and the two parties' status are recovered like initially.

Rendered awards shall be recognized as binding and pecuniary obligations shall be enforced "as if it were a final judgement of a court in that State". ${ }^{9}$ However, it is important to know that there is a case for waiver of immunity from execution for host state when it comes to national foreign sovereign. ${ }^{10}$

Overtime, ICSID has proved its leading role as one of the most prevalent fora among investors and States. The number of investment cases that administered by ICSID and applied ICSID rules is the highest of all, comparing to other applicable rules and other institutions (Figure 1.2). According to ICSID annual report, the centre administered a record of 247 cases over the course of the past fiscal year. In other words, in fiscal year 2016 ICSID administered about $43 \%$ of its entire caseload, which stands at 570 ICSID cases as of June 30, 2016 (Figure 1.3). As of June 30 2017, ICSID had registered a total of 619 ICSID cases $^{11}$, in which ICSID Convention arbitration covers 555 cases (89.7\%) and for Additional Facility there are 54 arbitration cases (8.7\%). A major of cases resolved due to Tribunal awards (64\%), the rest are either settled or discontinued $(36 \%)$.

\footnotetext{
${ }^{8}$ See Article 52.1 ICSID Convention for grounds for annulment

${ }^{9}$ Article 54.1 ICSID Convention

${ }^{10}$ Article 54.3 and 55 ICSID Convention

${ }^{11}$ ICSID, The ICSID Caseload - Statistics, Issue 2017 - 2
} 


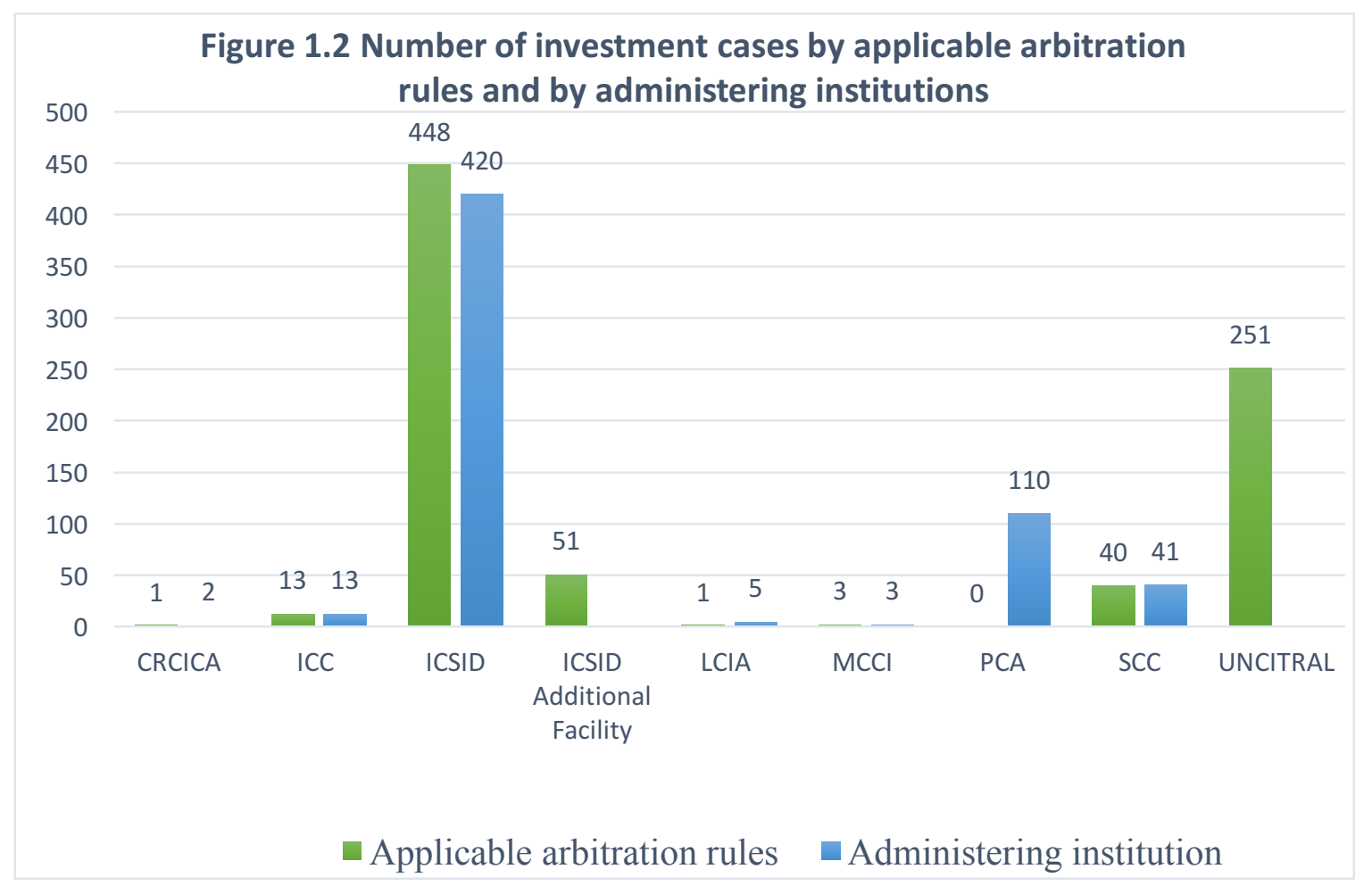

(Source: UNCTAD database ${ }^{12}$ )

Figure 1.3 ICSID Cases administered by the Secretariat (FY2013-FY2016)

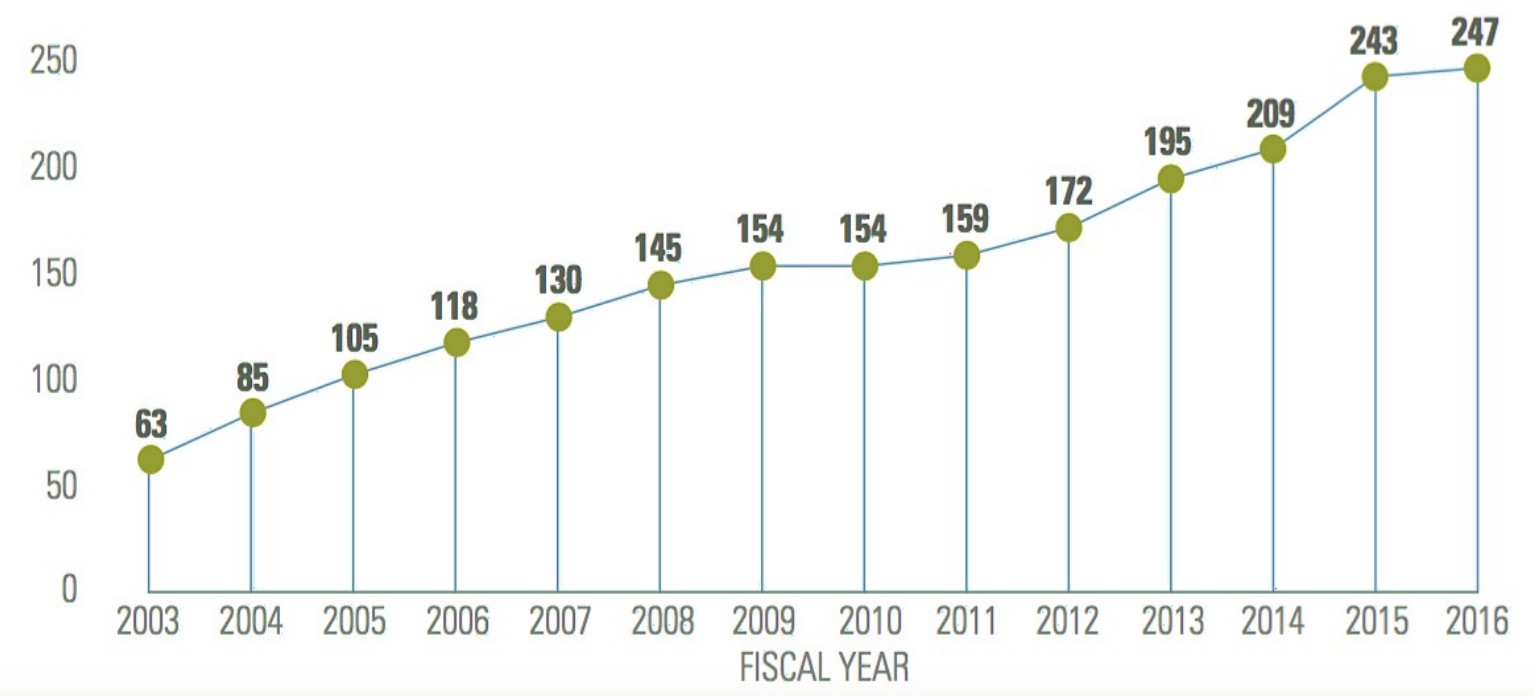

(Source: ICSID 2016 Annual Report)

${ }^{12}$ UNCTAD, Investment Policy Hub, http://investmentpolicyhub.unctad.org/ISDS/ 


\section{Other fora and arbitral rules for investor -State arbitration}

\section{The Stockholm Chamber of Commerce (SCC)}

Looking at the number of cases by applicable arbitration rules from Figure 1.2, we can see that the Stockholm Chamber of Commerce (SCC) ranks the third, showing its importance and popularity for investor-State disputes, just after the ICSID and UNCITRAL. In terms of administration of investor-state disputes, the SCC only ranks after the ICSID, which makes the SCC as the second largest forum in the world.

Since its first registered investment dispute in 1993, the SCC has played a leading role of a forum for ISDS arbitration in at least 120 BITs and in the Energy Charter Treaty, out of which 61 agreements stipulate that the SCC Arbitration Rules shall be applicable rules to investment disputes arising out of the agreements ${ }^{13}$. The UNCTAD database records that in total the SCC administered 41 investment cases and applied their own SCC Arbitration Rules on 40 investment cases ${ }^{14}$. Specifically, there are 9 ISDS cases currently pending, and the most recent case administered at SCC is newly this year 2017, between Puma Energy company and Benin government. Moreover, the SCC administered a case between Trinh Vinh Binh and Vietnam Government in 2004, which was quite much interested by Vietnamese legal and business community. The case was settled pursuant to the UNCITRAL arbitral rules and under the Netherlands - Vietnam BIT in 1994.

The internationality of the SCC is represented in the nationalities of the SCC's composition, the geographic distribution of cases, and also the economic sectors involved in the disputes. The composition of the SCC is made up of two elements: A Board of directors and a Secretariat. ${ }^{15}$ The Board, which includes various nationalities from China, Egypt, Germany, Russia, Sweden,

\footnotetext{
${ }^{13} \mathrm{SCC}$ website http://sccinstitute.com/dispute-resolution/investment-disputes/

${ }^{14}$ UNCTAD (n 12) updated in 13th November 2017

${ }^{15}$ Article 1, Appendix I, SCC Arbitration Rules
} 
Switzerland, UK and USA, shall make decisions related to the administration of disputes such as prima facie jurisdiction, consolidation, arbitrator's appointment, etc. ${ }^{16}$ The Secretariat consists of three legal divisions which support respectively two parties and the tribunals. This organization is necessary and properly convenient since the legal division shall acts as a communication channel between the parties and the tribunal, providing legal counsel, administrative assistance as well as taking decisions on the advance on $\operatorname{costs}^{17}$.

Last year 2016 was regarded as an outstanding year for the SCC with the number of 199 cases administered at the SCC, the third highest caseload since when it was founded in 1917. Out of this nearly 200 cases, more than half of them (52\%) were international and the rest (48\%) are Swedish ${ }^{18}$. Specifically, the disputing parties come from 44 different countries chose to settle their dispute at the SCC, for instance, USA, Germany, Russia, Ukraine, and Azerbaijan were the most frequent parties at SCC. The balanced ratio between foreign and domestic case settled at SCC shows that the SCC is a preferred arbitration institution by both Swedish and international business community.

Finally, regards to the wide coverage of the SCC, nationalities of arbitrators and economic sectors should be mentioned. Arbitrators represented in SCC cases came from 29 different nations in total ${ }^{19}$. The top four nations with most frequently appointed arbitrators are Sweden, UK, Germany and USA. The disputes settled at SCC arise from various economic sectors, including Oil, gas and mining sector (34\%); Electricity and power (29\%); Services and Trade (29\%); Construction (4\%) and Information and Communication (4\%).

\footnotetext{
${ }^{16}$ Article 6, Appendix I, SCC Arbitration Rules. For further statistics of SCC, see Investor-State disputes at the SCC, Celeste E. Salinas Quero, Arbitration Institute of the SCC.

${ }^{17}$ Article 8, Appendix I, SCC Arbitration Rules

${ }^{18}$ SCC website: http://www.sccinstitute.com/statistics/

${ }^{19}$ Celeste E. Salinas Quero, 'Investor-State disputes at the SCC', Arbitration Institute of the SCC.
} 


\section{International Chamber of Commerce (ICC)}

International Chamber of Commerce constituted the International Court of Arbitration as an arbitration body that aims to handle business conflicts among businesses across the world and provide technical assistance for parties in need. Despite of being called a court in name, ICA does not give judgments. Their goal is to ensure that ICC rules are applied properly to administrate arbitral proceedings, helping disputing parties resolve conflicts and finally result in a binding award. Since established in 1923, there have been 22,000 disputes administered by ICC $^{20}$ and the institution's Rules of Arbitration now are worldwide used to resolve disputes. In January 2017, ICC has just released a report of the growth of ICA in 2016 and preliminary statistics revealed that in 2016, the Court received 966 new requests for arbitration involving 3,099 parties from 137 countries $^{21}$. Among those, there are 4 cases were investment disputes $^{22}$. Up to date, the case between a Turkey construction company and Libya government (Ustay Yapi Taahut ve Ticaret AS v. Libya) is the first and newest investment dispute filed to ICC in 2017. This is a record year for the Court in its 94 years of history. Particularly in South and East Asia, ICA continues to expand its foothold in the region at the beginning of 2016 with an overall increase of $22 \%$ in the number of parties participating, with a record 82 parties from Korea.

The court is widely renowned for its flexibility, neutrality and various resolution services. ICC set up a dispute board as a permanent panel in order to help parties avoid any disagreement arising during the performance of their contracts. There are three types of dispute board available for choices: Dispute Adjudication Boards whose decisions that must be complied with immediately,

\footnotetext{
${ }^{20}$ ICC website: https://iccwbo.org/

${ }^{21}$ Ibid.

${ }^{22}$ UNCTAD (n 12)
} 
Dispute Review Boards whose recommendations that are not immediately binding and finally, Combined dispute boards whose solution is intermediate between the other two. Parties wishing to use the Dispute Board Rules should include an appropriate reference in their contract.

Along with giving administration to arbitration cases, the Court also plays an active role in education of dispute settlement. The ICC frequently holds different training programs for lawyers, arbitrators and judges in international arbitration, most of which are implemented by the ICC Institute of World Business Law. This is a body established especially for research and educational purposes. The Institute's training programs involves multiple levels from basic introductory courses to more advanced workshops, often with mock arbitrations.

ICC has sufficiently acted as the bridge between various parties individuals, businesses and governments - involved in international arbitration and surely their ongoing efforts would make ICC arbitration services more accessible in the future.

\section{London Court of International Arbitration (LCIA)}

Followed the Paris - based ICC, The London Court of International Arbitration (LCIA) is another world's leading forum for resolving disputes. The London court only refers to its headquarters in London. The major international characteristic of the LCIA is projected most clearly through the proportion of $80 \%$ of pending LCIA parties are not of English nationality. ${ }^{23}$ The wide range of alternative dispute resolution (ADR) related services are provided by LCIA to all contractors without any membership requirements.

The organizational structure of the LCIA is made up of three major elements: The Company, the LCIA Court of Arbitration, and the LCIA

\footnotetext{
${ }^{23}$ LCIA website http://www.lcia.org/LCIA/introduction.aspx
} 
Secretariat. The Company's main role is designating the members of the LCIA Arbitration Court. The Court bears no judicial power but the final authority for the LCIA rule application. Its main responsibilities are tribunal appointment, arbitrator challenge determination and cost control. The upper limit of the number of members for the LCIA's Arbitration Court is 35. The President, up to seven Vice-Presidents and the Director General constitute the Arbitration Court's officers. The LCIA Secretariat helps administer all cases that referred to the LCIA on daily basis, both cases under its own rules (including arbitration and ADR services) and cases under UNCITRAL rules as well. Up-to-now, there are 6 investment case administered by the LCIA, in which five investment cases was under UNCITRAL Arbitral Rules, and one was under its own LCIA Arbitral Rules.

\section{Permanent Court of Arbitration (PCA)}

Along with ICSID, ICC and LCIA, the PCA is among the most prominent international dispute settlement institution. The Permanent Court of Arbitration (PCA) was one of the most concrete achievements from the First Hague Peace Conference in 1899. Within the scope of the First Hague, the Convention for the Pacific Settlement of International Disputes had 26 signatories, were aimed to develop a platform for international dispute resolution. The Convention expressed the favour towards arbitration as it is the "most effective, and at the same time the most equitable, means of settling disputes which diplomacy has failed to settle" ${ }_{24}$.

As a by-product from the 1899 Convention, the PCA was inaugurated:

$[w]$ ith the object of facilitating an immediate recourse to arbitration for international differences which it has not been possible to settle by diplomacy, the signatory Powers undertake to organize a Permanent

\footnotetext{
${ }^{24}$ Article 16, Convention for the Pacific Settlement of International Disputes 1899
} 
Court of Arbitration, accessible at all times and operating, unless otherwise stipulated by the parties, in accordance with the rules of procedure inserted in the present Convention.

Today the PCA is headquartered at the Peace Palace in The Hague, the Netherlands and has become an intergovernmental organization providing a wide range of services for dispute settlement, especially the ones related to oceans or sea laws, through peaceful means: arbitration services, mediation, conciliation, appointing authority and fact-finding commissions. Despite the name 'permanent court', the PCA is not necessarily a permanent international judicial body. It has no sitting judges and the parties themselves select the arbitrators under the supervision of the appointing authority (The SecretaryGeneral). A standing body is the Administrative Council, consisting of diplomatic representatives of all member nations and the Foreign Minister of the Netherlands as Chairman of the administrative council. The Board is responsible for providing general guidelines and supervising the operation of the PCA.

They have greatly satisfied the fast-growing dispute settlement needs on a global scale thanks to its nature being perfectly combined of both public and private aspect of international law. All parties whether States, States entities or private corporations and arbitrators seeking to conduct arbitral proceedings under the PCA's auspices are provided access to its administrative services. According to the PCA Annual Report, during the year 2016, the PCA has administered 148 cases in total, in which 86 cases are ISDS arbitration arising under BIT/multilateral investment treaties or national investment laws ${ }^{25}$. The institution has not released its annual report for 2017, but up to the moment, the UNCTAD database records that the PCA has administered 110 investment

${ }^{25}$ PCA Annual Report 2016 
case $^{26}$. The number of administered cases at PCA is continuously increasing, especially with 4 cases just within this year 2017.

In terms of the procedure for resolving disputes, the PCA does not have specific procedural rules applied for all cases, they offer four sets of procedural rules that different types of party may use for arbitration, such as:

- the Optional Rules for Arbitrating Disputes between Two States (1992)

- the Optional Rules for Arbitrating Disputes between Two Parties of which Only One is a State (1993)

- the Optional Rules for Arbitration between International Organizations and States (1996) and

- the Optional Rules for Arbitration between International Organizations and Private Parties (1996)

However, due to the records of the UNCTAD database, there has been no case under PCA arbitral rules; all of the 110 investment cases have been proceeding under UNCITRAL rules.

\section{UNCITRAL Arbitration Rules}

Besides having their own arbitration rules, all institutions that introduced above do conduct arbitral proceedings under UNCITRAL Arbitration Rules if it is upon agreement of parties. In other words, unlike with ICSID, there is no dedicated institution associated with the administration of arbitrations pursuant to the UNCITRAL Arbitration Rules. Instead, the organizational work for the ad hoc arbitration must be undertaken by the tribunal and the parties. However, the parties may employ the services of administration from institutions such as ICSID, PCA, etc.

${ }^{26}$ UNCTAD (n 12) 
Moreover, due to nature, there are certain differences between these two most prominent arbitral rules, especially about the challenge, and the enforcement of the awards. Regards to ICSID arbitration, the investment dispute is placed under the framework of an international treaty - ICSID Convention. All signatories to the dispute is bound to respect the obligations under the ICSID Convention. Thus, under the convention, foreign investors can have access to an international remedy, and national courts in party states of the Convention is bound to recognize ICSID arbitration award as if it were a final judgment of a court; unless the award falls within one of the grounds for annulment provided by the ICSID Arbitration Rules. Therefore, the enforcement of final ICSID awards will be solid and highly probable, due to the binding institutional regime ${ }^{27}$. For the UNCITRAL Arbitration (as non-ICSID Arbitration), the recognition and enforcement of final arbitral awards is most likely governed by the New York Convention 1958. So far, the Convention has a very wide scope of signatories - up to 157. Basically, the grounds for a national court to annul an arbitral award in the NYC are covered similarly as in the ICSID annulment grounds listed above; but some notable additional grounds under the NYC are:

- the national law in the court of enforcement does not permit arbitration of the subject matter of the dispute; or

- recognition or enforcement would be otherwise contrary to public policy ${ }^{28}$

This comprehensive set of arbitration rules of UNCITRAL which mostly provided for in bilateral investment treaties (BITs) covers all aspects of the arbitral process providing a model arbitration clause, regulating in terms of arbitrator's appointment and procedural proceedings, as well as enforcement and interpretation of the award. In fact, most arbitration rules of institutions are commonly based on UNCITRAL's with a few amendment or supplement. First

\footnotetext{
${ }^{27}$ Piero Bernardini, 2009, 'ICSID versus Non-ICSID Investment Treaty Arbitration'.

${ }^{28}$ Article V.2 the New York Convention 1958
} 
adopted in 1976, now the latest version of UNCITRAL Arbitration Rules is the 2013 version which incorporates the "UNCITRAL Rules on Transparency for Treaty-based Investor-State Arbitration". Compared to the previous time of revision in 2010, the 2013 revision only add the new Article 1, paragraph 4 clarifying the application of the Rules on Transparency in arbitration under UNCITRAL Rules. This revision shows a consideration of the Commission regards of transparency challenge. It is noteworthy that if arbitration agreements (including those contained in BITs) were made before the date that the 2010 UNCITRAL Arbitration Rules were concluded (August 15 $5^{\text {th }} 2010$ ), then the arbitration is instead subject to the 1976 version, unless the parties agree otherwise.

As can be seen, the procedural rules of UNCITRAL are widely chosen for ISDS especially in 'ad hoc' arbitration. Next to a choice of institutional arbitration (with the supervision of an arbitral institution), the ad hoc arbitration is gaining prevalence as another arbitral option that investors and States can choose to settle their disputes with. But due to the nature of happening for specific situation, data on ad-hoc arbitration, however, is off the record. Moreover, investors would like to 'rule shopping' for those arbitral rules which provide the highest level of confidentiality. However, this limitation in public disclosure raises concerns for public industries - such as environment, health and safety, etc. The new rules on transparency hope to tackle this challenge.

\section{The role of ISDS in international investment}

Regard to stakeholders in investment contractual relationship

Perhaps the ISDS arbitration is mostly favoured by investors, enterprises and businessmen because of its business-friendly nature. As long as the arbitration is consensual, whether contractual or not, and the agreement is made 
before or after the arisen dispute, it can still be enforceable. ${ }^{29}$ We can take the words of Lord Hoffman as an explanation for the preference for arbitration in business community. Accordingly, 'rational businessmen' have reasonable expectations that the purpose of arbitration agreement can answer:

...In approaching the question of construction, it is therefore necessary to inquire into the purpose of the arbitration clause. As to this, I think there can be no doubt. The parties have entered into a relationship, an agreement or what is alleged to be an agreement or what appears on its face to be an agreement, which may give rise to disputes. They want those disputes decided by a tribunal which they have chosen, commonly on the grounds of such matters as its neutrality, expertise and privacy, the availability of legal services at the seat of the arbitration and the unobtrusive efficiency of its supervisory law. Particularly in the case of international contracts, they want a quick and efficient adjudication and do not want to take the risks of delay and, in too many cases, partiality, in proceedings before a national jurisdiction ${ }^{30} \ldots$

Even though his words were taken in a context of a contractual business relationship between two enterprises, but we can see that the arbitration agreement in business is very important as it allows parties to resolve their disputes that may arise from their business relationship in a peaceful and effective manner. Given that nature, an investment treaty between two states offer the same purpose of investment protection to investors. By giving consent to arbitration clause in an investment treaty, States allow investors to actively seek for remedy in case of a dispute arises out of their investment that caused by a mistreatment from the States instead of waiting for States' exercise of

\footnotetext{
${ }^{29}$ Section 6 of The Arbitration Act 1996, Model Law

${ }^{30}$ Premium Nafta Products Limited and others Vs. Fili Shipping Company Limited and others, Opinions of the Lords of Appeal for Judgement in the cause, Session 2006-07, [2007] UKHL 40
} 
diplomatic protection. This means States provide investment protection to foreign investors- a welcome mat that reassures foreign investors enjoy fair treatment as domestic ones ${ }^{31}$. In investment activities - a business relationship between investors and the governments, it is unavoidable that expropriation, or nationalization, or a political measure undertaken by the government may injury economic interests of foreign investors; in that case, arbitration for reparation is vital.

According to PwC and Queen Mary University of London, the preferences of corporations for international arbitration to resolve their crossborder dispute has also increased, from $73 \%$ in 2006 to $90 \%$ in $2015 .^{32}$ Accordingly, the top valuable characteristics of ISDS to investors are "enforceability of awards", "avoiding specific legal systems," followed by "flexibility" and "selection of arbitrators". In other words, the choice to resolve disputes in a third, neutral forum and the binding decisions are what makes international arbitration, or ISDS, become indispensable.

If we take a broader look, we can see that stakeholders in ISDS have more to tell. According to OECD survey, investors-claimants range from "individuals with quite limited international experience" to small, medium, large and major multi-national enterprises. ${ }^{33}$

In our view, ICSID benefits both investors and host States. First of all, ISDS benefits investors who are disadvantaged at a biased domestic court or

\footnotetext{
${ }^{31}$ Gary Clyde Hufbauer, 'Investor-State dispute settlement', in Trans-Pacific Partnership: An assessment, Volume 104 of Policy Analyses in International Economics, Cathleen Cimino-Isaacs and Jeffrey J.Schott, July 2016, Peterson Institute for International Economics.

32 PricewaterhouseCoopers (PwC) and Queen Mary, University of London, '2015 International Arbitration: Improvements and innovations in International Arbitration', http://www.arbitration.qmul.ac.uk/docs/164761.pdf The Survey had conducted a survey every two years since 2006, and also in 2013, 2015, giving insights to international arbitration in the real business world. Their research take more than 700 corporations/ respondents, stakeholders in international arbitration at many levels, into account to find out about their choices, their preferences and attitude regard to dispute settlement.

${ }^{33}$ OECD (n 3). The survey based on 50 ICSID cases and for 45 UNCITRAL cases.
} 
protective policy in the host States that they conduct investment ${ }^{34}$. If before, investors can only seek help at national courts, and lack of protection of rights, not to mention some domestic legislation are accompanied with political lobbying and corruption; now with ISDS mechanism, they are given a chance to side-step what may be incompetent and choose what best advantaged for them. This key advancement of ISDS in international investment, however, also raised some questions about the equality between standards of protection for foreign investors and those that apply to domestic investors. If a foreign investor can bring a claim against a state for compensation when their investment is mistreated, domestic investor cannot do so. This issue, thus, leave the room for improvement in each state's legislation.

ISDS can also generate benefits for host states as well. Given the arbitration tool to protect investors' rights and benefits, investors would feel more secured to do business even if host states' regulation has limitations and from that host states can attract more investment. Moreover, the rapid development of ISDS creates pressure to reform domestic conflicts resolution procedures, otherwise, states would have to spend much of time and resources in political resolution of investment and trade disputes. The pressure of monetary compensation for investors pursuant to rendered award can urge host states to improve domestic judicial practices to be in line with international standards. An alternative view is that ISDS does have negative effects. The fact that foreign investors are granted a "privilege" unavailable to domestic ones "exposes" domestic Government (of the host State) to the risk of being challenged and sued against for compensation by foreign nationals. State sovereignty and public interest regulations should never be questioned, and ISDS appears to be superior to national domestic laws. The mere fact that foreign investors can challenge a governmental policy before a tribunal that is

\footnotetext{
${ }^{34}$ David Gaukrodger, Kathryn Gordon, OECD Working Papers on International Investment 2012/03, Investor-State Dispute Settlement: A scoping paper for the investment policy.
} 
outside the domestic court systems, then three arbitrators of the tribunal aboard can order the Government of host State pay reimbursement to the investor is arguable ${ }^{35}$.

Regard to international investment promotion of nations

Figure 1.3 Basis of consent invoked to establish ICSID jurisdiction in new cases registered in FY2016 under the ICSID Convention and Additional Facility rules

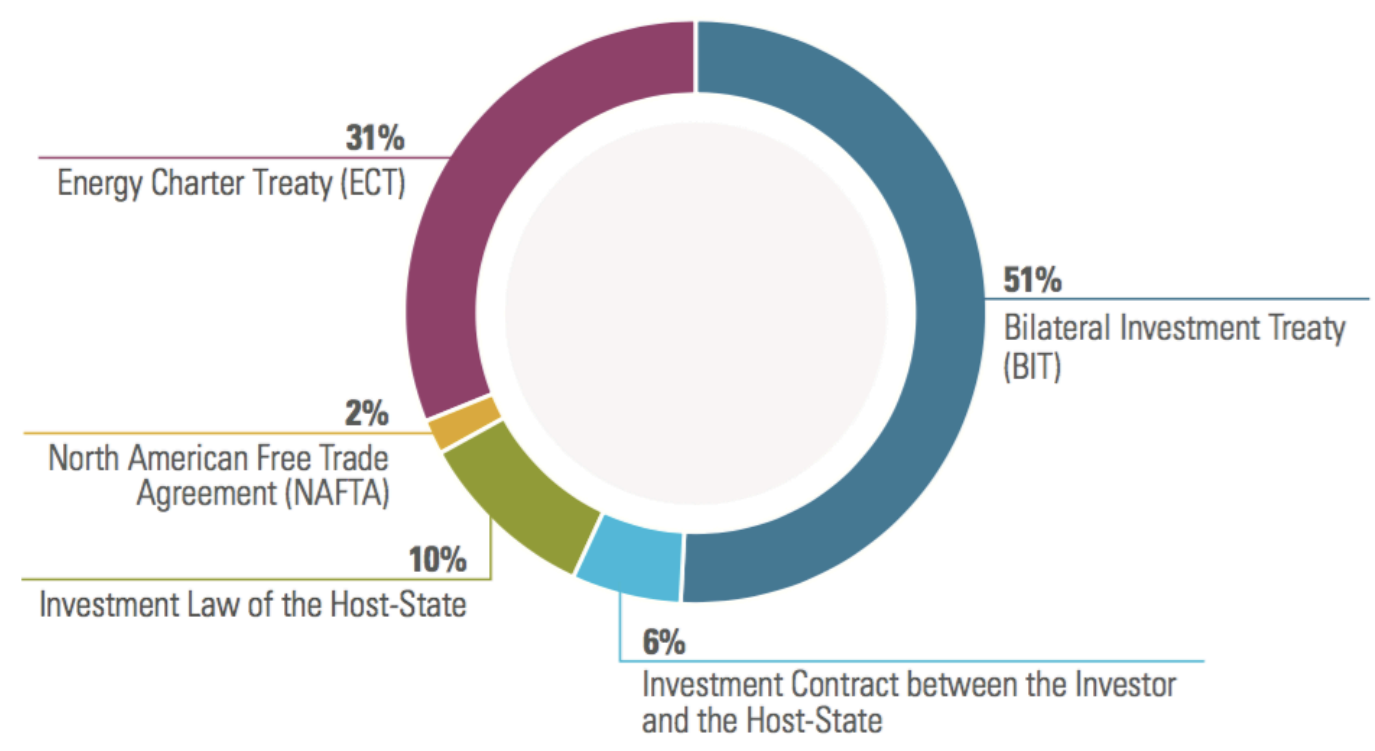

(Source: ICSID Annual Report 2016)

Via the basis of consent invoked to establish ICSID jurisdiction in new cases registered in fiscal year 2016, we can notice that the most major part of the cases invoked ICSID jurisdiction are from bilateral or multilateral investment treaties, up to $51 \%$ of the consent basis. Cases stem from investment law of host-state and investment contract cases take the percentage of 10 and 6 respectively. This ratio somehow reflects a dispensable part of ISDS provisions in IIAs. There are total 3324 IIAs worldwide, including 2363 BITs in force and

\footnotetext{
${ }^{35}$ Scott Miller, Gregory N.Hicks, Investor-State Dispute Settlement: A Reality check, A Report of the CSIS Scholl Chair in International Business, Center for Strategic \& International Studies (CSIS), January 2015.
} 
309 TIPs in force ${ }^{36}$. If we take a look at the world largest economy - the United States $^{37}$ - they have included investment chapters in nearly all of its 20 FTAs to promote their investment aboard. In other words, a principal goal of IIAs is to promote investment and ISDS provisions are crucial tool to support. Even though there is a common belief that ISDS provisions benefits developing countries more than what it does to developed countries in IIA relationship, this is still an international playground and the measure is open for every country to access and make use of.

Figure 1.4 Number of investor-state dispute settlement (ISDS) case, 1987, 19932017

\section{Trends in known treaty-based ISDS cases, 1987-31 July 2017}

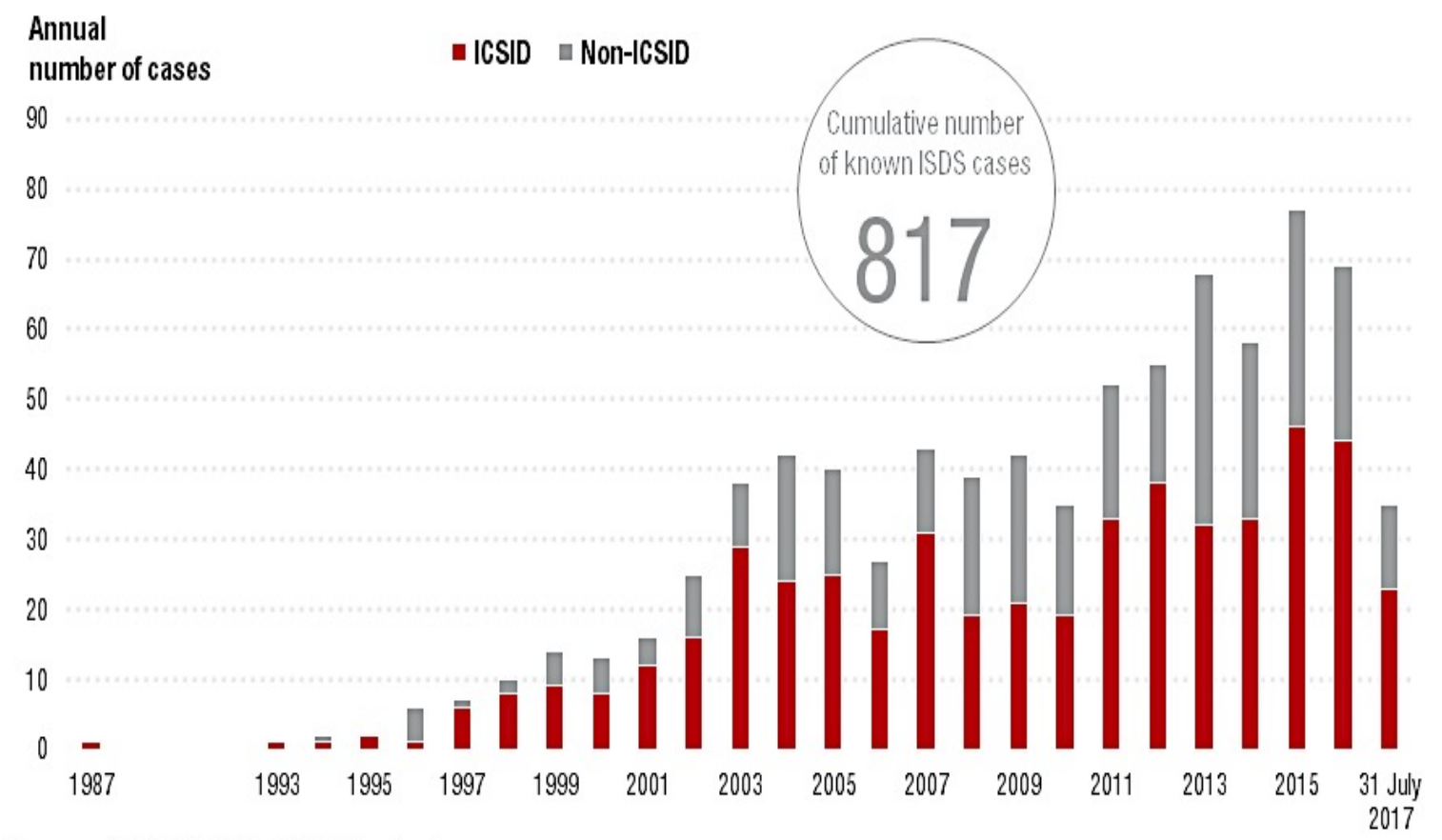

Source: OUNCTAD, ISDS Navigator.

\footnotetext{
${ }^{36}$ UNCTAD (n 12)

${ }^{37}$ Over the past decades, only 16 ISDS cases have been brought against the United States while US investors are ahead of the curve with 148 ISDS cases as claimants. And among those 16 cases, United States has not lost in any cases as the country is advanced in developing legislation on investment to create a friendly business environment.
} 
Figure 1.5 World FDI inflow 2005-2016, and projections 2017-2018 (billions of dollars and per cent)

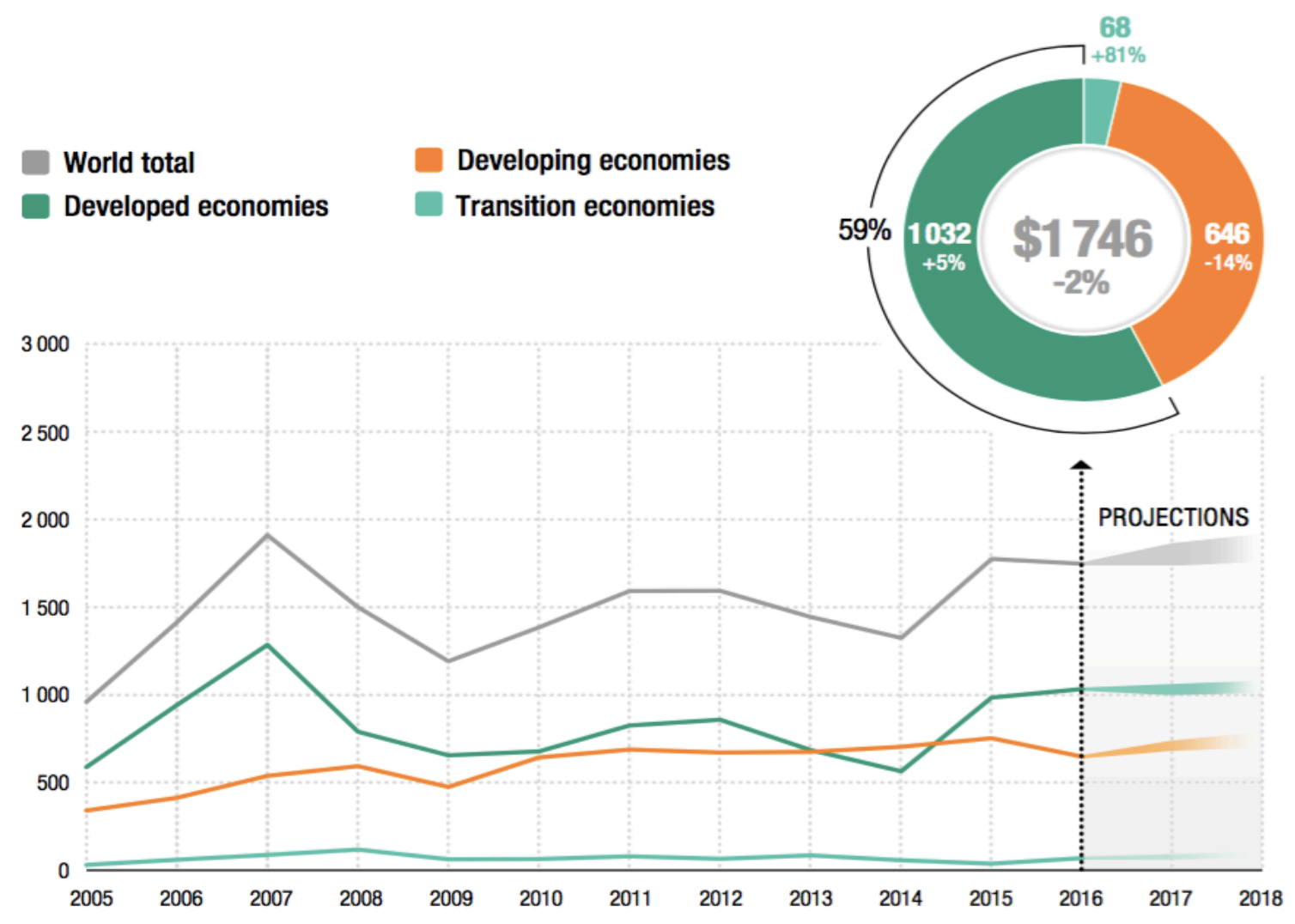

Source: CUNCTAD, FDI/MNE database (www.unctad.org/fdistatistics).

Figure 1.6 Trends in IIAs signed 1980 - 2016 


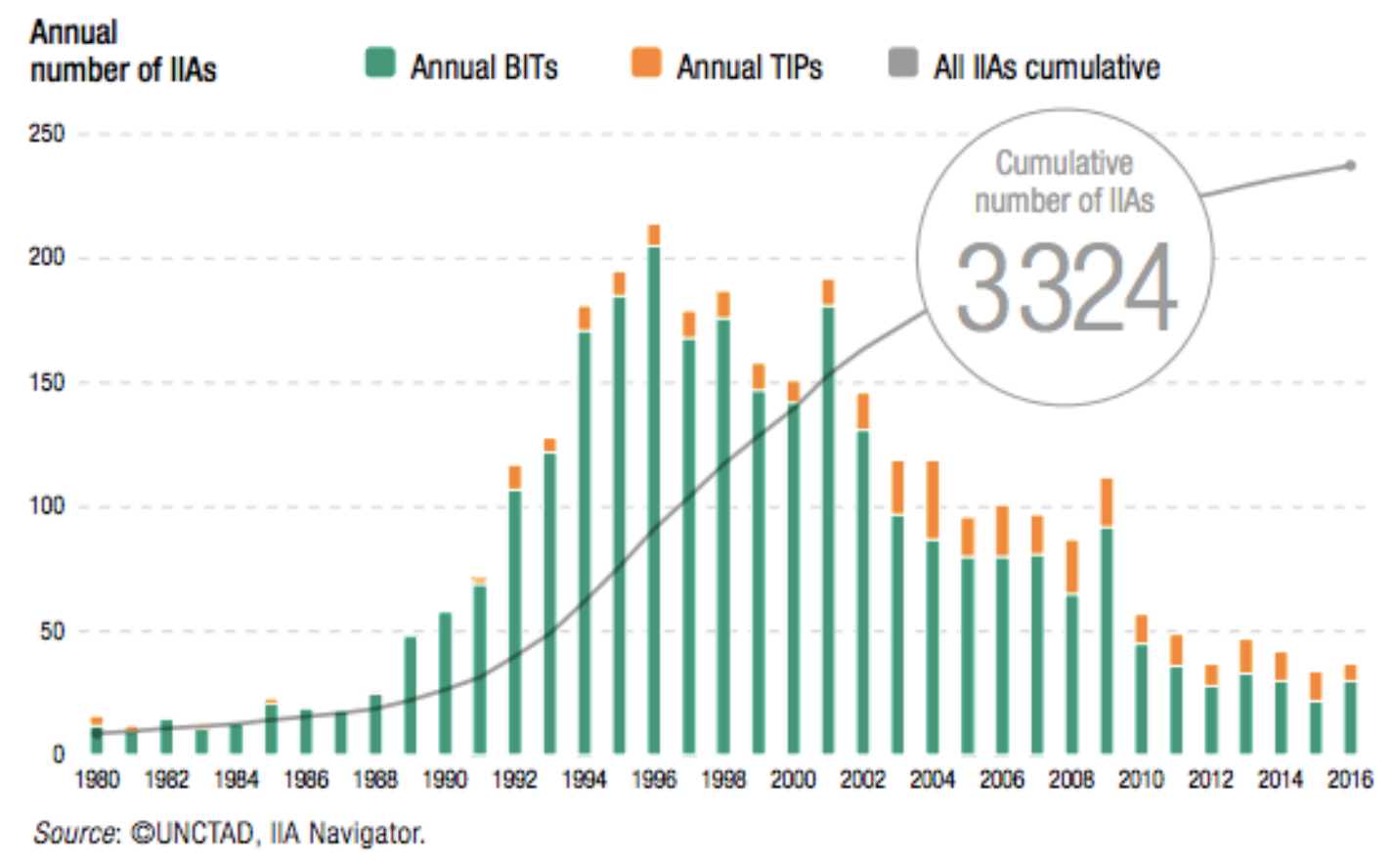

Gary Clyde Hufbauer drew the attention to the relevant among three elements: number of ISDS cases, FDI, and number of BITs concluded ${ }^{38}$ Looking at Figure 1.4 and Figure 1.5, we can see that the number of ISDS cases worldwide has steadily grown and in analogous pattern of rise with FDI and number of cumulative number of IIAs, especially in the period 2005-2016. Since 2005, although the world's total FDI inflows fluctuates, it shows a general upward trend from 1100 billion $\$$ to 1746 billion \$ (Figure 1.5). The number of IIAs also rose from 2,506 agreements in 2005 up to total 3,324 agreements (2957 BITs and 367 TIPs) in 2016" (Figure 1.6). Since the beginning of 2017, there are 11 IIAs signed (7 BITs and 4 TIPs), in which one TIP between China and Hong Kong entered into force in this June. The statistics of new treaty-based ISDS cases continues unabated: 77 initiated cases in 2015, 69 cases initiated in 2016, and 35 new cases in the first 7 months of 2017, bringing the total number of known treaty-based ISDS cases to 817 as of 31 July 2017. Since this is just the number for known cases, due to the nature of confidentiality of ISDS

\footnotetext{
${ }^{38}$ Gary Clyde Hufbauer (n 31)

${ }^{39}$ UNCTAD (n 12)
} 
arbitration, the actual hidden number of investor-State disputes must be higher. In words of Gary Hufbauer, more FDI certainly creates "more opportunities for friction between firms and states, and the growing number of ISDS cases simply tracks a world economy in which BITs and FTAs are designed both to entice FDI and to ensure fair play thereafter".

\section{Part 2. EU proposal for an international investment court}

\section{The trend of a multilateral investment court system (ICS): TTIP, CETA}

Apart from the two popular types of arbitral options for ISDS which are institutional arbitration and ad hoc arbitration as introduced in the first part of this paper, today public attention is drawn to a new permanent investment court system that the Commission of EU is introducing in their recently negotiating trade deals: The CETA with Canada, the TTIP with the US and later the EVFTA with Vietnam (they are also known as the 'new generation' trade deals). This new mechanism is expected to replace and reform the traditional arbitration-based system and improve certain limitations that it has long received. This second part of the paper aims to deliver some highlights of this new investment court in EU's ongoing trade deals: TTIP ${ }^{40}$ EU proposal, CETA and mainly focused on EVFTA.

The EU and Canada have signed the trade agreement at the end of October 2016, and The European Parliament has voted in favour on 15 February

\footnotetext{
${ }^{40}$ Hereafter in this paper, TTIP is referred to the EU's proposal for TTIP and there is no assurance that the US is going to accept it; the negotiation is still in the process.
} 
2017 but that does not mean CETA is a done deal. A noteworthy point about CETA is that after a month since the final text of the EU-Vietnam FTA was released, CETA immediately dropped in the new ICS to replace its traditional ISDS mechanism ${ }^{41}$, similar to the TTIP EU proposal, whereas CETA text was already finalized and in the process of legal revision. Public did not be aware of this amendment during the process. The ICS belongs to the exclusions from provisional application of CETA, which means now CETA must go through the final stage of ratification before fully entering into force. It must be approved by all EU national parliaments according to their respective domestic constitutional requirements - that would make CETA a mixed agreement ${ }^{42}$. However, if CETA is supposed to be a mixed agreement that needs all Member States approval to ratify, a 'provisional application' of an agreement before it has been approved might facilitate circumvent democracy. For TTIP EU proposal, the negotiation is still in progress; but according to the limited available TTIP chapters as EU's proposal, the function, constitution and operation of ICS are basically regulated similarly among these three trade deals.

At US market, currently EU is the biggest investor with investments value of more than $€ 1.6$ trillion. Now EU is making efforts in ensuring a level playing field and providing more certainty for both EU and US investors. This helps EU to attract investment from US and remain competitive internationally as well. Under both TTIP EU proposal and CETA, the negative perception of foreign investor is blurred as some fundamental guarantees are provided to both side, such as no discrimination on the grounds of investors' nationality, gender,

\footnotetext{
${ }^{41}$ European Commission Press Release of 29 February 2016 http://europa.eu/rapid/press-release IP-16-399 en.htm

${ }^{42}$ An EU-only agreement enters into force straight after the European Parliament gives its approval while mixed agreements enter into force only once each individual EU country has approved it. Each country's approval procedures may take several years, so in the meantime EU governments can decide in the EU Council to provisionally apply the agreement ('provisional application'). The main exclusions from provisional application of CETA are: investment protection; investment market access for portfolio investment (except market access for FDI); the Investment Court System; an article on camcording.
} 
race or religious beliefs; no expropriation of investors' assets (e.g. by nationalization without compensation, etc.

TTIP EU proposal, CETA and EVFTA both emphasize on the fair and equitable treatment as a standard of investment protection. This is an advancement since fair and equitable has been identified by some as one of the elements of the minimum standard of treatment of foreigners and of their property, required by customary international law ${ }^{43}$. Investors are under no circumstance should be denied a possibility to bring a legitimate claim to the courts of the host country. A denial of justice in criminal, civil or administrative proceedings is a breach of the obligation of fair and equitable treatment to investors as regulated in TTIP EU proposal ${ }^{44}$ and in $\mathrm{CETA}^{45}$. The TTIP EU proposal even goes more detailed than CETA that it stated "obstacles to effective access to justice" is included as a breach of due process. The treaty allows an investor to bring a claim the Investment Court in case there is a breach of one or more of the listed obligations which shall be reviewed regularly by both sides of the agreements. The Committee on Services and Investment, established under CETA, takes charge of developing recommendations in this regard, and they will submit recommendations to CETA Joint Committee for final decision. However, the approach to "fair and equitable" in form of a "closed" list that exists in TTIP proposal, CETA and even EVFTA is arguable:

"A Party breaches the obligation of fair and equitable treatment [...] where a measure or a series of measures constitutes:

(a) denial of justice in criminal, civil or administrative proceedings; or

\footnotetext{
43 "Fair and Equitable Treatment Standard in International Investment Law", OECD Working Papers on International Investment, 2004/03, OECD Publishing.

${ }^{44}$ Article 3.2, Section 2, Chapter II, TTIP

${ }^{45}$ Article 8.10, para 2, Section D, Chapter 8 CETA
} 
(b) fundamental breach of due process, including a fundamental breach of transparency and obstacles to effective access to justice, in judicial and administrative proceedings; or

(c) manifest arbitrariness; or

(d) targeted discrimination on manifestly wrongful grounds, such as gender, race or religious belief; or

(e) harassment, coercion, abuse of power or similar bad faith conduct; or

(f) a breach of any further elements of the fair and equitable treatment obligation adopted by the Parties in accordance with paragraph 3 of this Article." 46

Above is the list of prohibitions regards to fair and equitable treatment in TTIP EU proposal text. CETA and EVFTA provide mostly similarly. Adding the word "constitute" means measures that breach fair and equitable standard obligation are defined and limited to what only falls within the list. This limitation could result in the fact that there might be some measure that does not belong to the list, but still cause an unfair and discriminative treatment between domestic investors and investors of the other Party. In contrast, the draft text of TPP - in which used to include the U.S, and Canada was curiously absence in the most recent meeting about TPP at the side-line of APEC 2017 trade talks provide a more "open" definition of fair and equitable treatment:

"fair and equitable treatment" includes the obligation not to deny justice in criminal, civil or administrative adjudicatory proceedings in accordance with the principle of due process embodied in the principal legal systems of the world..."

The word "include" implies that the following listed obligations are inter alia, not only limited to what are mentioned in the provision, which probably is a better use. TPP draft text also sets the fair and equitable treatment provision in a form of just "minimum standard of treatment" for investors, which means

${ }^{46}$ Article 3.2, Section 2, Chapter II, TTIP European Commission draft text 
member States must treat investors at least at that standard, and they are encouraged to offer more.

A noteworthy point is that the EVFTA lists the breach of obligation to treat just slightly different: without "a fundamental breach of transparency" 47 , while TTIP EU proposal and CETA provide that a breach of transparency constitutes a breach of fair and equitable treatment obligation. Vietnam has been recognized for having low records in transparency, according to the World Economic Forum. In annual reports for competitiveness in 137 economies around the world, in the past two years Vietnam has been ranked quite low, at $88^{\text {th }}$ in 2016 and $82^{\text {nd }}$ in 2017 out of 137 economies, in terms of transparency in public policy making ${ }^{48}$. Given Vietnam's established reputation for weak performance in transparency, could this be construed that the EU is easier on Vietnam with looser regulation on transparency than on the U.S and Canada, who is famous for efficiency of legal regime?

EU's agreements limit the grounds on which investors can challenge a state that only claims relating to non-discriminatory treatment and investment protection provisions can be submitted to the $\mathrm{ICS}^{49}$. Firms would not be able to sue governments just because their profits are affected. They will have to provide sufficient law and factual basis to demonstrate that a public authority has breached the provisions in agreements. Both CETA and TTIP EU proposal include articles that preserve fully the right of governments to regulate in public interest ${ }^{50}$. This clarifies that a measure that may negatively affect an investment or affect an investor's expectations of profits is not inconsistent with the agreement for that reason alone. Such vigilant regulation can help public bodies avoid being forced to change legislation or pay damages. CETA even forms a

\footnotetext{
${ }^{47}$ Article 14.2, Section 2, Chapter 8 EVFTA

${ }^{48}$ World Economic Forum, Global Competitiveness Report 2016-2017; and World Economic Forum, Global Competitiveness Report 2017-2018.

${ }^{49}$ Article 8.18, Section F, CETA and Article 1, Section 3, Chapter 8, TTIP.

${ }^{50}$ Article 8.9, Section D, CETA and Article 2, Section 2, Chapter 8, TTIP.
} 
system that allows the Court to issue fast-track rulings ${ }^{51}$. These provisions can save a lot of time while the Tribunal can dismiss frivolous or unfounded claims in a matter of weeks.

\section{Composition of the ICS:}

In terms of organizational structure, the court is a two-tier system that comprises of a Tribunal (of First Instance) and an Appeals Tribunal. However, the number of tribunal system provided among TIIP EU proposal, CETA and EVFTA is different.

For TTIP EU proposal, the tribunal has 15 judges $^{52}$, quite a large number indicating the big scope of member states involved, five of EU nationals, five of US nationals and five nationals of third countries). A division of three judges one EU judge, one US judge and one judge from a third country - is assigned to hear case. This division is appointed randomly on a rotation basis to ensure their equal opportunity to serve and fairness. CETA provides for a similar number of Tribunal members, with five members being nationals of Canada, five members being EU nationals, and the remaining five members are third country nationals ${ }^{s .}$. The appointment of Tribunal members is entirely undertaken by a specialized committee, consists of representatives from Parties and established under the agreement. Under TTIP it is the Service and Investment Committee and under CETA, it is the CETA Joint Committee.

For TTIP EU proposal, the Appeals Tribunal composes of six judges (two EU nationals, two US nationals and two nationals of other countries) ${ }^{54}$. The EU and US propose three candidates respectively (two nationals of their own and one non-national). The tenure for judges in Appeals Tribunal, and its hearing division is similar to the regulations for the Tribunal. For CETA, the number of

\footnotetext{
51 Articles 8.32 and Article 8.33, Section F, Chapter 8, CETA

${ }^{52}$ Article 9, Section 3 Chapter II. Investment, TTIP Agreement

${ }^{53}$ Art. 8.27, para. 2, respective Art. 8.28, para. 7, Section F, CETA

${ }^{54}$ Article 10, Section 3 Chapter II, TTIP Agreement
} 


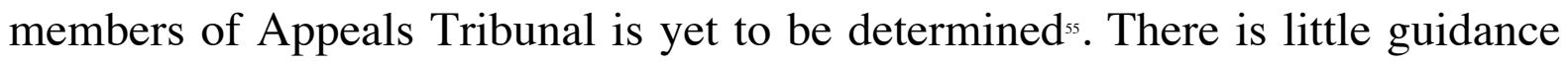
on the constitution and operation of Appellate Tribunal. Administrative and organizational matters regarding the functioning of the Appellate Tribunal shall have to wait for further decision from the CETA Joint Committee in the coming time. So far, we just know that the division of "three randomly appointed Members of Appellate Tribunal" shall hear the appeal. The Appellate Tribunal will review decisions of the Tribunal and the grounds for reviewing awards are clearly defined in both agreements.

However, the number for members of Tribunal in ICS between EU and Vietnam is completely different: only 9 members. Detailed contents of ICS Tribunal in EVFTA will be discussed afterwards, but first looking at the overall quantities of members in these three Tribunals, we notice an inconsistency across EU's proposals.

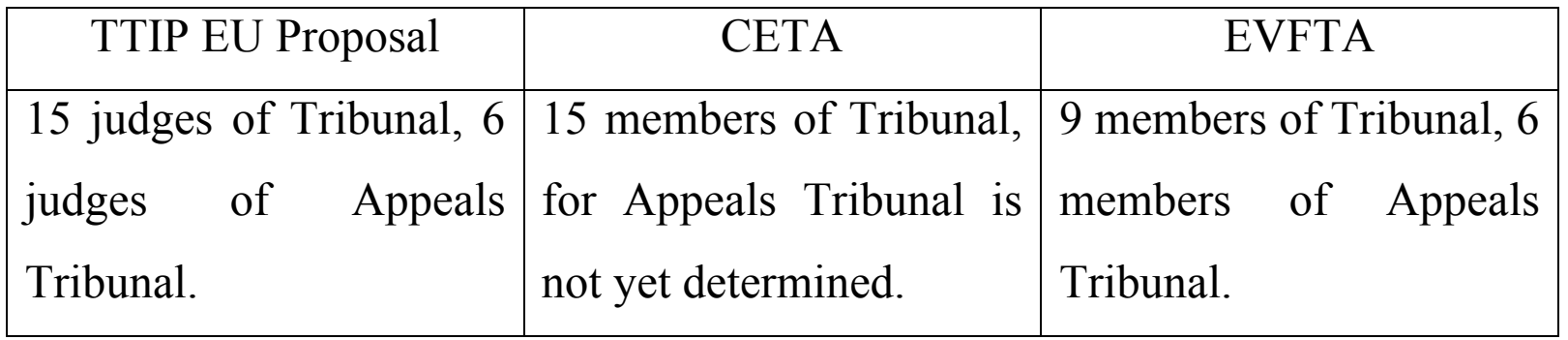

A question raised is that why Tribunal in the FTA with Vietnam is so much fewer than with Canada and the U.S. A reasonable way to look at a scope of an institution is based on the scope of population of the country it is placed, but in respect to population, Vietnam has population of 92 million while Canada has only more than 32 million population ${ }^{56}$, so this explanation is not satisfying. Would the quantity represent a distinction hidden between developing and developed country, or an assumption that Canadian and the U.S investors might use the Tribunal more frequently?

\footnotetext{
55 Art. 8.28, Section F, Chapter 8, CETA

${ }^{56}$ The popluation was in 2016, according to data source of World Bank.
} 
The tenure of elected judges is long - six years, and there are seven judges who "appointed immediately after the entry into force of the Agreement, to be determined by lot", shall hold the chairs for nine years. In contrast to a tribunal panel that happens 'ad hoc', this fixed long-term position can raise concern about the independence and politicization of the court.

The number of Tribunal members is not yet explained, but this two-tier system is a clear break from a standard arbitration practice which empowers the investor and the state involved to actively nominate the arbitrators who would hear their cases.

\section{Standards requirement for members of ICS}

There are certain standards for eligibility of judges in ICS. Members of tribunals shall possess the qualifications required in their respective countries for judicial offices while for members of Appeal tribunals it should be equivalent to the highest judicial offices. Rules on ethics are provided:

"They shall not be affiliated with any government. They shall not take instructions from any government or organisation with regard to matters related to the dispute. They shall not participate in the consideration of any disputes that would create a direct or indirect conflict of interest. In so doing they shall comply with Annex II (Code of Conduct). In addition, upon appointment, they shall refrain from acting as counsel in any pending or new investment protection dispute under this or any other agreement or domestic law. "57

Pursuant to TTIP, to maintain such 'beyond doubt' independence, a judge in Tribunal receives a monthly retainer fee which is suggested to be around only one third of the retainer fee for WTO Appellate Body members (i.e. around $€$ 2000 per month). It is questionable whether this small amount is enough to guarantee the independence, not to mention that the judges must be available at

${ }^{57}$ Article 11, Section 3, TTIP 
all times, even in short notice, and stay updated with dispute settlement activities under the agreement. According to CETA, no specific amount of retainer fees is mentioned yet, but those shall be determined pursuant to Regulation 14.1 of the Administrative and Financial Regulations of the ICSID Convention.

\section{A look at the investment court in EVFTA}

After CETA and TTIP, the EU-Vietnam FTA (EVFTA) contributes to EU's roadmap to reform investment protection. The EU even commented the agreement with Vietnam as "the most ambitious and comprehensive FTA that the EU has ever concluded with a developing country". Not only issues in trade, but ISDS is also tackled. The ICS is proposed in EVFTA and both of these three treaties include an article saying that the Parties shall share the objective of pursuing with other trading partners the establishment of a multilateral investment court for the resolution of investment disputes. The EVFTA were substantially concluded in 2015 and expected to come into effect in 2018. The ICS of the EVFTA is basically outlined similar to TTIP EU proposal and CETA's. Overall, the court is regarded as having certain improvements over the existing WTO dispute settlement but at the same time still remains certain concerns and criticism against.

\section{Right to regulate:}

As in the TTIP proposal and the CETA, EU's agreement with Vietnam includes an Article about regulatory measures as a safeguard for governments' right to regulate. Since it is unsure to know if whether the U.S is going to accept EU proposal or not, we shall compare the Right to regulate article between EVFTA and CETA.

\section{EVFTA}

Article 13bis: Investment and
CETA

Article 8.9: Investment and regulatory 


\begin{tabular}{|c|c|}
\hline ves & mea \\
\hline $\begin{array}{l}\text { 1. The Parties reaffirm the right to } \\
\text { regulate within their territories to achieve } \\
\text { legitimate policy objectives, such as the } \\
\text { protection of public health, safety, } \\
\text { environment or public morals, social or } \\
\text { consumer protection or promotion and } \\
\text { protection of cultural diversity. }\end{array}$ & $\begin{array}{l}\text { 1. For the purpose of this Chapter, the } \\
\text { Parties reaffirm their right to regulate } \\
\text { within their territories to achieve } \\
\text { legitimate policy objectives, such as the } \\
\text { protection of public health, safety, the } \\
\text { environment or public morals, social or } \\
\text { consumer protection or the promotion and } \\
\text { protection of cultural diversity. }\end{array}$ \\
\hline $\begin{array}{l}\text { 2. For greater certainty, the provisions of } \\
\text { this section shall not be interpreted as a } \\
\text { commitment from a Party that it will not } \\
\text { change the legal and regulatory } \\
\text { framework, including in a manner that } \\
\text { may negatively affect the operation of } \\
\text { covered investments or the investor's } \\
\text { expectations of profits. } \\
{[\ldots]}\end{array}$ & $\begin{array}{l}\text { 2. For greater certainty, the mere fact that } \\
\text { a Party regulates, including through a } \\
\text { modification to its laws, in a manner } \\
\text { which negatively affects an investment or } \\
\text { interferes with an investor's expectations, } \\
\text { including its expectations of profits, does } \\
\text { not amount to a breach of an obligation } \\
\text { under this Section. } \\
{[\ldots]}\end{array}$ \\
\hline
\end{tabular}

Although the expression between two Articles is not exactly the same, but their nature is alike: stipulating that a claim for compensation shall not be made against a legitimate governmental action for public interests. In both agreements, it is not in the jurisdiction of the Tribunal to determine the legality of a measure, under the domestic law of the disputing party (this will be discussed in the following part). However, first and foremost, in EVFTA text, it is said 'the' right to regulate while in CETA the words are changed to 'their' right to regulate. One might interpret here that it implies Canada has had their right to rule already established, claimed, and recognized, and now Vietnam is just being allowed to rule in its territories, not sure if that authority is acknowledged to belongs to Vietnam by international.

In EVFTA, Article 13b clearly reaffirms that governments' right to regulate within their territories for legitimate policy objectives is fully 
preserved. Legitimate policy objectives must fall within the scope of public interests such as "health, safety, environment or public morals, social or consumer protection or promotion and protection of cultural diversity". The article clarifies that investment protection provisions cannot be interpreted as a commitment by governments not to change their laws in the future, even if there is a manner may negatively affect the investor's expectations of profits. The approach of right to regulate is pretty new in IIA; Vietnam has never particularly included in its signed IIA before such a clause specifically preserving its right to rule. This regulatory measure provision might help to avoid the abuse of ICS in the future and help the agreement to create a balance between investment protection and autonomy.

However, in our opinion overall the approach of the right to regulate for benefits of public is too subjective and leaves too much flexibility. A better way to look at it is a state's regulations must be consistent with its obligations under the treaty. Necessary measures for public welfare are measures that serve the state's obligations. Thus, saying a mere fact of changing a law, including a manner that affect negatively investors' expectations of profits does not amount to a breach of obligation under this provision is not enough. Furthermore, the fact that this naïve approach is combined with the exhaustive list of FET violations clearly favours the States against investors' expectations.

\section{Applicable law \& rules of interpretation:}

Apart from the structure and wordings of the text, the provisions for Applicable law and interpretation are generally similar between the EVFTA (Article 16) and CETA (Article 8.31), with some minor differences.

\begin{tabular}{|c|c|}
\hline EVFTA & CETA \\
Article 16: Applicable law and rules of & Article 8.31: Applicable law and \\
interpretation & interpretation \\
\hline
\end{tabular}




\begin{tabular}{|c|c|}
\hline $\begin{array}{l}\text { - The Tribunal does not have jurisdiction } \\
\text { to question the legality of a measure, } \\
\text { alleged to constitute a breach of this } \\
\text { Agreement, under the domestic law of } \\
\text { the disputing Party (para.2). } \\
\text { - determine whether the measures in } \\
\text { question are inconsistent with Article } \\
1.1 \text { (Scope) (para.1) }\end{array}$ & - similar to EVFTA (para.2) \\
\hline $\begin{array}{l}\text { Applicable laws in rendering decisions: } \\
\text { - This Agreement, } \\
\text { - other rules or principles of international } \\
\text { law applicable between EU and } \\
\text { Vietnam, } \\
\text { - and take into consideration domestic law } \\
\text { of disputing parties as a matter of fact } \\
\text { (para.2) }\end{array}$ & $\begin{array}{l}\text { Applicable laws in rendering decisions: } \\
\text { - this Agreement } \\
\text { - other rules and principles of } \\
\text { international law applicable between } \\
\text { EU and Canada (para.1) } \\
\text { * Domestic law may be considered, as } \\
\text { appropriate, as a matter of fact while } \\
\text { determining the consistency of a measure. }\end{array}$ \\
\hline $\begin{array}{l}\text { Interpretation of domestic law: carried by } \\
\text { the courts and binding to the Tribunal, not } \\
\text { vice versa (para.2) } \\
\text { Interpretation of the Agreement: shall be } \\
\text { in accordance with customary rules of } \\
\text { interpretation of public international law, } \\
\text { as codified in the Vienna Convention on } \\
\text { the Law of Treaties (para.3). }\end{array}$ & $\begin{array}{l}\text { Interpretation of the Agreement: } \\
\text { similar to the EVFTA (para.1) }\end{array}$ \\
\hline
\end{tabular}

Under both agreements, determining whether a measure under domestic law is legal remains the monopoly of the government of Parties to the Agreement. As a safeguard, the reason for this is to permit the Parties to control and influence the interpretation of the agreement. 
When adjudicating and rendering its decision, the Tribunal shall apply the agreement in accordance with the principles of international law applicable between the Parties. A difference between the EVFTA and CETA is that: in EVFTA, the Tribunal shall take into consideration the relevant domestic law of disputing party as a matter of fact. While in CETA, the domestic law is probably considered in appropriate circumstances for determining the consistency of measure with CETA; in other words, the domestic law of disputing parties in CETA is not used in the process of rendering decisions by the Tribunal.

In both agreements, the Tribunal shall use the interpretation of domestic laws of disputing parties given by the domestic courts of that parties. Interpretation of domestic law given by the courts or authorities who are competent to interpret is binding upon the Tribunal, but any meaning given to the relevant domestic law made by the Tribunal is not binding upon the courts and the authorities of either Party.

\section{- Submission of a claim}

The EVFTA regulates the obligation of 'fair and equitable treatment' and 'full protection and security' as a standard treatment of investment for parties. Basically, one can submit a claim while there is a measure undertaken by a Party that breach either Section 2 (Investment protection) or Section 1 (national treatment, MFN treatment) that allegedly causes loss or damage to the claimant. To avoid parallel claims, a claimant may not submit a claim if the claimant has a pending claim before any other domestic or international court concerning the same measure.

\section{Conducts of proceedings}


EVFTA incorporates the UNCITRAL Rules on transparency. Accordingly, all documents - including submissions by the parties to a dispute, and the tribunal's decisions - shall be available to public. However, compared to the Transparency of proceedings provision in CETA, the EVFTA is still loose and has not achieved far reaching in transparency. Under CETA, all hearings are open to public ${ }^{58}$. So far in Vietnam there is no such access to documents of a proceeding or access by the public to hearings. This practice does not help either Vietnamese investors or government well prepared in lawsuit and ready for international competitive market.

\section{Composition of the court}

A Tribunal panel for first instance of conventional ISDS by arbitration, in ICSID proceedings for example, normally includes three members. Specifically, each party will appoint two names, one for arbitrator of their choice and one for proposed President of the tribunal. And the appointed arbitrator must not have the same nationality to either of the two parties ${ }^{59}$. If they cannot reach consensus on such issue, arbitrators of Tribunal will be chosen by the Council for them. This constitution of tribunal can be understood as based on the appointment that totally excluded the factor of nationality. The EVFTA offers differently. The Tribunal includes 9 members, in which 3 members shall be nationals of each party (in this case, Vietnam and member states of the EU) and the remaining are nationals of third countries. The Tribunal then hear the cases in division of three which shall be chaired by a member who is a national of third country. ${ }^{60}$ The Appeals Tribunal consists of six members, with similar regulation for the ratio of nationality of members. ${ }^{61}$ This even categorization based on the affiliation to the parties is also proceeded in TTIP EU proposal and CETA agreements. These EU's agreements keep the factor of nationality for

\footnotetext{
${ }^{58}$ Article 8.36, CETA

${ }^{59}$ Article 37.2 (b) Arbitral rules, ICSID Convention

${ }^{60}$ Art. 12 para 6, Section 3, Chapter 8, EVFTA

${ }^{61}$ Article 13, Section 3, Chapter 8 EVFTA
} 
favour of parties in its regulation but leave all matters regards the appointment to specialized committee (in EVFTA it is the Trade Committee, upon recommendation of the Committee on Services, Investment and Government Procurement ${ }^{62}$ ). Moreover, only in EVFTA, the possibility of disputing parties proposing members of tribunal as the precedent regulation in conventional ICSID is remained but modified as another alternative ${ }^{63}$.

By eliminating the participation of the disputing parties on the nomination of a particular panel, the ICS responds to frequent criticism over the influence of investors over the arbitration process. This approach is generally welcomed as a reformative feature compared to the traditional ISDS system, but on the other hand, having the Parties choosing panel judges in advance, inserts a significant element of political influence - counteracting the objective of depoliticization that ISDS was designed to achieve.

\section{Standards requirement for members of the ICS}

Stricter requirement of independence and integrity expresses a demanding requirement from the European Commission but somehow slightly ambiguous. Beside possession of required qualifications in respective countries for appointment to judicial offices, or be jurist of recognised competence, ${ }^{64}$ members must have demonstrated expertise in public international law in order to become eligible. Expertise in international investment law, international trade law, and international dispute resolution is ideal. Nevertheless, any measurement to demonstrate such expertise is not suggested. Notably, members of Appeal Tribunal must meet the qualifications requirement to be appointed to

\footnotetext{
62 Art. 34.2 EVFTA.

${ }^{63}$ Footnote 25 and 26, EVFTA.

${ }^{64}$ Art. 12, para. 4, EVFTA
} 
the "highest judicial office" as regulated in their respective countries, which implies an even higher threshold. This seems to imply that members of Appellate Tribunal are more qualified/expert at delivering judgement. Another issue is that there are definitely differences among member states of EU and Vietnam regarding the qualifications for judicial offices.

The EVFTA has devoted article 14 and Annex II-chapter 13 to stipulate for Ethics issue. The first ethical criteria for members of the Tribunal and the Appeal Tribunal is that their independence is "beyond doubt", which means they must not be affiliated with any government and do not participate in any disputes that would create a direct or indirect conflict of interest. Once appointed into Tribunal panel, they shall stop any other business, in which their roles are counsels, experts or witnesses, that related to either party's new or pending investment disputes under this or any other agreement or domestic law.

\section{An appeals mechanism}

The unavailable opportunity for a substantive review of tribunal's awards in traditional ISD judicial proceedings has long received controversial opinions from legal community. Under ICSID framework, there is an annulment committee and grounds to annul are limited. With the ICS, Vietnamese and the EU investors as credit debtor can have a chance to challenge the tribunal award which becomes only provisional award and not yet a final one. The grounds to appeal the tribunal award are:

(a) that the Tribunal has erred in the interpretation or application of the applicable law;

(b) that the Tribunal has manifestly erred in the appreciation of the facts, including the appreciation of relevant domestic law; or,

(c) those provided for in Article 52 of the ICSID Convention, in so far as they are not covered by (a) and (b). 
The FTA with Vietnam provides competences for the Appeal Tribunal to "modify or reverse the legal findings and conclusions" of the Tribunal, partially or in toto. ${ }^{65}$ Only where the facts of the case do not allow for a final decision to be taken is the matter to be referred back to the Tribunal. ${ }^{66}$

The Tribunal renders only monetary damages and any applicable interest as compensation for the loss suffered by the claimant, not punitive damages because the Tribunal does not have jurisdiction to judge a measure of a government is legal or not, so the ICS does not have effect of repeal of a measure. This means that a measure, even though severely negatively affect an investor's business, cannot be stopped or repealed. All what the wronged party can get is receiving compensation for their losses.

The Tribunal shall issue a provisional award within 18 months since submission of the claim, then after 90 days if there is no disputing party appealed, the provisional award become final.

\section{Enforcement of awards}

According to Article 31 of EVFTA, the final awards issued by the ICS shall be binding between the disputing parties. Both Vietnam and the EU governments shall recognize the rendered award and enforce it as if it were a final judgement of a court in its authority. Once being 'final', rendered awards of ICS pursuant this Agreement shall not be appealed, reviewed, set aside or annulled $^{67}$. Notably, the Agreement gives Vietnam a period of 5 years, since its entry into force, to prepare for transition with the new tribunal system before Vietnam has to comply with the enforcement of binding awards in respect of disputes where Vietnam is a respondent. During this period of 5 years, the recognition and enforcement of a final award in respect of a dispute where

\footnotetext{
${ }^{65}$ Art. 28, para. 3, EVFTA; a decision of the Appeal Tribunal is considered final in accordance with Art. 29, para. 3, EVFTA.

${ }^{66}$ Art. 28, para. 4, EVFTA.

${ }^{67}$ Article 31, EVFTA.
} 
Vietnam is the respondent shall be conducted pursuant to the New York Convention.

Another worthy of note is the final paragraph in this Article which states that final award issued by the Tribunal shall qualify as an ICSID award. This leads us to a question: Is ICS final award truly equivalent to ICSID final award? A distinctive feature of ICSID award is its 'automatic' enforcement. By 'automatic' it means all ICSID final awards shall be recognized by all state parties to the ICSID Convention and enforced as if it were a final judgment of a court in that state ${ }^{68}$. In other words, if a party to the proceeding fails to comply with the ICSID award at his State, the other party can seek remedy elsewhere in other Contracting States of the Convention; he can bring the pecuniary obligations to any ICSID Member states to have them recognized an enforced in their domestic courts as if it were a final judgment of that State's courts. However, saying ICS Tribunal's award is considered an ICSID award is highly subjective and irrelevant. An arbitral award rendered by the ICS of EVFTA, between an EU and Vietnamese disputing parties is an issue upon the free trade agreement between the EU and Vietnam. A court in Norway, or Switzerland, or Turkey, for example, has no responsibility to recognize and enforce pecuniary obligations for a dispute between EU and Vietnamese parties.

Article 12 referring to a possibility of a multilateral dispute settlement mechanism seems to serve EU's intention to fix the problem mentioned above. However, the obligation under the ICSID Convention is open to debate because other international treaties governing arbitration such as the NYC 1958 or the Panama Convention still leave room for a level of domestic court's review with limited grounds in setting-aside proceedings to ensure the award is consistent to its public policy. Thus, establishment of a multilateral investment court with same ICSID automatic enforcement regime is highly questionable.

${ }^{68}$ Article 54, ICSID Convention 


\section{Comments on the ICS}

Indeed, the ICS resolve limitations that the traditional ISDS arbitration system did not, such as the 'forum shopping' capacity where an investor goes to a court where they think they're most likely to win. ICS allows judges to dismiss claims early on if they consider them to be unfounded, saving more time and cost because it requires the lost party in case to bear all costs of hearings (the loser pays principle) to deter the investors from making frivolous claims in the first place. The judges or tribunal members are prohibited from acting as counsel in investment cases, which removes the so-called 'double hat' problem in ISDS. Nevertheless, the ICS receives a wave of oppose for other reasons. Civil society mainly concerns that whether there is a need for such special investor protection. A foreign investor can seek fairness and equitable treatment but at the same time the door is opened for firms to sue against State as well with no other way around. It can be affectious to public interest and taxpayers.

Despite the same constitution and operation of the two-tier system including Tribunal and Appellate Tribunal, only the proposal of ICS in the TTIP agreement the word "court" is used in the heading. It uses the title "judges" for members of the First Instance Tribunal only (but not for the Appeal Tribunal). In the EVFTA and CETA neither the words "court" or "judges" are used, they name it 'The Investment Tribunal System' and 'members' of Tribunal, members of Appellate Tribunal. Questions rise about the purpose of naming the investment court differently among these agreements, whether an award of the investment court under these EU's FTA is an arbitral award - which fall inside the scope of the New York Convention or it is a judicial judgement. Given the facts that the ICS relies on existing arbitration rules (including those of ICSID arbitration and UNCITRAL), and there is no permanent secretariat is created like a permanent judicial body, and the cost is mostly shared by the disputing parities. As stated in the EU-Vietnam agreement text, two parties shall 
recognize and enforce the issued award as if it were a final judgement of a court in its authority. This removal of set-aside of awards appears to be dissonant with claims of increased public accountability made by the EU Commission and self-contradictory with the balance achieved between the autonomy of arbitration and the duty of control by States at the time of enforcement. This is going to be an issue for Vietnam - a developing country - in the context of a multilateral investment court in the future is not far-fetched. After the EVFTA comes into effect, EU firms can gain more impacts on equitisation of Vietnamese State-owned enterprises who for long get used to subsidy and monopoly in the market. EU firms will be able to bid for public contracts such as infrastructure, mineral sources, power distribution, public hospitals, etc. Whereas foreign investors are given elevated protection treatment, now it's time for Vietnam to review and revise its legislation framework and prepare for the application of an investment court, and certainly likely a multilateral investment court in the future.

\section{Part 3. Recognition and enforcement of foreign arbitral awards in Vietnam}

In its centenary conference in 2015, the Chartered Institute of Arbitrators (CIArb) introduced its CIArb Centenary London Conference Principles (the Principles), which are 10 principles described as those characteristics necessary for an effective, efficient and safe seat for the conduct of international commercial arbitration ${ }^{69}$. Similarity, in a survey of Queen Mary University, London with the White \& Case $\operatorname{Ltd}^{70}$, the most important elements that explain

\footnotetext{
${ }^{69}$ The ten principles include: law, judiciary, legal expertise, education, right of representation, accessibility and safety, facilities, ethics, enforceability, immunity. http://www.ciarb.org/docs/defaultsource/ciarbdocuments/london/the-principles.pdf?sfvrsn=4

${ }^{70}$ Queen Mary University of London (n 32)
} 
the choice of seat of arbitration are local legal system, national arbitration law, track record for enforcing arbitral awards, availability of quality arbitrators, etc. In general, these elements for a safe and efficient platform for international dispute settlement can be classified into two main categories: domestic legislation environment and international influence on arbitration.

\section{Legislation}

In Vietnam, arbitration activities are governed by:

\section{a. The Law on Commercial Arbitration}

The main legislation governing the arbitration in Vietnam right now is The Law on Commercial Arbitration No. 54/2010/ QH12 (hereafter the LCA) which was ratified by National Assembly on June $17^{\text {th }} 2010$, taking effect since $1^{\text {st }}$ January 2011. Arbitration activities in Vietnam are at early developing stage and do not have a long-founded background. There has no legal text that stipulates arbitration yet until 2003 with the introduction of the Ordinance on Commercial Arbitration (Ordinance No.08/2003/PL-UBTVQH11) and the LCA in 2011 is to replace it. This was indeed a remarkable first step for Vietnam in strengthening legal framework for constitution and operation of arbitration activities in Vietnam. The LCA makes efforts to bring arbitration in Vietnam in line with the international practice. The law of Vietnam adopts fundamental principles of dispute settlement by arbitration from the UNCITRAL Model Law of 2006, with some differences.

The Model Law on International Commercial Arbitration was firstly adopted by the UNCITRAL in 1985, with amendments in 2006; it serves UNCITRAL's objective to constitute a harmonized basis for States in establishing their arbitration laws. It covers comprehensive aspects of 
arbitration from procedures to recognition and enforcement of arbitral awards. The UNCITRAL Model Law is neither an actual law or a binding convention, but it appears as a prototype of law, a suggested legal framework for States around the world to adopt; States are encouraged to incorporate the Model Law into their legal system and make a few changes as possible, to increase the likelihood of achieving a harmonization in international arbitration, to decrease the variations among legal systems, in the interest of the users of international arbitration $^{71}$. Fundamental principles of UNCITRAL include:

(i) Independence of arbitration agreement: Article 7 as amended in 2006 confirms the validity and effect of an arbitration agreement to resolve any arisen disputes or disputes may arise in the future in any form (written or oral) as long as the content of consensus is recorded. Article 16 affirms the independence arbitration agreement. It means that an arbitration clause shall be treated separately as an independent agreement of the other terms of the contract. "A decision by the arbitral tribunal that the contract is null and void shall not entail ipso jure the invalidity of the arbitration clause" (Article 5, Model Law 2006)

(ii) Delimitation of court intervention: Courts' involvement in arbitration is defined and limited through a group of articles in the Model Law, regarding issues of appointment, challenge of arbitrators, evidence collecting, interim measures, etc. In short, apart from the authorized duties regulated in the Model Law, "no court shall intervene, in matters governed by this Law" (Article 5). The supervision and assistance of courts are very necessary, but the fact that parties agreed to arbitrate means they have a consensus to exclude court intervention in the dispute and their arbitral proceedings should be protected from disruptive court interference. Both this principle and the principle above about independence of arbitration agreement reflects that the parties' choice to use arbitration must be respected.

\footnotetext{
${ }^{71}$ Explanatory Note by the UNCITRAL Secretariat on the 1985 Model Law on International Commercial Arbitration as amended in 2006, http://www.uncitral.org/pdf/english/texts/arbitration/mlarb/MLARB-explanatoryNote20-9-07.pdf
} 
(iii) Competence-competence: or internationally known as the "Kompetenz-Kompetenz" principle, which means the competence to rule on its own jurisdiction. Accordingly, arbitral tribunal are competent to determine its own jurisdiction, including any objections with respect to the existence or validity of the arbitration agreement, without having to resort to a court.

(iv) Fundamental procedural rights of a party: This principle means that the parties shall be treated equally and have full opportunity to present their case (Article 18). Both parties will select procedural rules, seat of arbitration, language of proceedings upon agreement, otherwise the arbitral tribunal may determine for them.

Based on the UNCITRAL Model Law, the LCA adopts nearly the same spirit of the Model Law through its provisions, with a few differences as indicated in its wording way. Specific contents of LCA shall be discussed later, but first we shall take a look at some significant similarities and differences between the LCA and Model Law.

On the surface, the principle (i) of Model Law regarding the independence of arbitration agreement has been adopted by the LCA, via Article 16 and 19. In Vietnam laws, arbitration agreement also exists as a separate agreement with full valid, regardless of the contract. However, Vietnam laws request arbitration agreement to be in written forms (i.e. emails, fax, telegrams, etc.), unlike Model Law which allows for oral agreement as long as the content is recorded. The Model Law principle (ii) is also expressed by Article 6 of LCA, saying that the court is obliged to deny jurisdiction if an arbitration agreement already established between parties, unless the agreement is void. The principle (iii) of Model Law with respect to arbitration tribunal's competence to rule on its jurisdiction also lies in the Article 43 of LCA. Finally, the principle (iv) of Model Law has been embodied to the LCA's principle, at Article 4 regarding principles of dispute settlement by arbitration in Vietnam, providing that parties are given equal rights and obligations. 
Moreover, there are some significant differences between the LCA and the Model Law. The table below sums up a few different regulations between LCA and the Model Law, followed by further detailed analysis of the LCA.

\begin{tabular}{|c|c|c|}
\hline & $\begin{array}{c}\text { Vietnam Law of Commercial } \\
\text { Arbitration (LCA 2010) }\end{array}$ & $\begin{array}{l}\text { UNCITRAL Model Law } \\
2006\end{array}$ \\
\hline $\begin{array}{l}\text { Qualifications } \\
\text { of arbitrators }\end{array}$ & $\begin{array}{l}\text { Set forth such qualifications to } \\
\text { ensure that disputes are settled } \\
\text { by reliable arbitrators (Article } \\
\text { 20). }\end{array}$ & $\begin{array}{l}\text { Not set forth the qualifications, } \\
\text { only saying that if parties fail } \\
\text { to determine the number of } \\
\text { arbitrators, the number shall be } \\
\text { three. }\end{array}$ \\
\hline $\begin{array}{l}\text { Registration } \\
\text { of an ad hoc } \\
\text { arbitral award }\end{array}$ & $\begin{array}{l}\text { An award of ad-hoc arbitration } \\
\text { is required to be registered at } \\
\text { the court "in the locality where } \\
\text { the arbitral tribunal issued } \\
\text { such award prior to any } \\
\text { request to the competent civil } \\
\text { judgement enforcement } \\
\text { agency to organize } \\
\text { enforcement of the award" } \\
\text { (Article 62). Registration or } \\
\text { non-registration shall not } \\
\text { affect the contents and validity } \\
\text { of such award. }\end{array}$ & $\begin{array}{l}\text { Model Law does not provide } \\
\text { for this issue. }\end{array}$ \\
\hline $\begin{array}{l}\text { Grounds for } \\
\text { setting aside } \\
\text { an arbitral } \\
\text { award }\end{array}$ & $\begin{array}{l}\text { "if the arbitral award is } \\
\text { contrary to the fundamental } \\
\text { principles of the law of } \\
\text { Vietnam" (Article 68) }\end{array}$ & $\begin{array}{l}\text { "if the arbitral award is in } \\
\text { conflict with the public policy } \\
\text { of this State" (Article } 34.2 \text { ) }\end{array}$ \\
\hline
\end{tabular}


Unlike the Model Law whose principles are embodied through its text, the LCA of Vietnam has a specific Article 4 named "principles for dispute settlement by arbitration":

\section{Vietnam LCA's Principles of arbitration for dispute settlement}

$>$ "Arbitrators must respect the agreement of the parties if it does not breach prohibitions and is not contrary to social morals ${ }^{72}$.

Arbitrators must be independent, objective and impartial and must comply with the provisions of law.

> Parties in dispute shall have equal rights and obligations. Arbitration tribunals shall be responsible to facilitate the parties to exercise their rights and to discharge their obligations.

> Dispute resolution by arbitration shall be conducted in private, unless otherwise agreed by the parties.

> An arbitral award shall be final."

While the obligation of arbitrators to respect the agreement of the parties (Article 4.1) expresses the principle of party autonomy, the ambiguity of what constitute a breach of prohibitions lead us to the ongoing debate about the definition of the rule of law in Vietnam. At the moment, Vietnam is aiming to develop into a socialist rule-of-law state - a concept that might be strange to democratic nations with trias politica. Thus, we can notice a shift in Vietnam legal texts' regulation from stipulating what is 'not prohibited' to stipulating what is 'allowed'. In other words, Vietnamese citizens now can do everything not prohibited by law. But this shift in regulating is in progress and Vietnam

\footnotetext{
${ }^{72}$ Social morals is an abstract concept in Vietnam. There is no legal document in Vietnam that defines the definition of social morality, so we can understand it as something that does not violate human ethics, does not go against the standards of society. There is only one small explanation of social ethics mentioned in Article 123 of the Civil code of Vietnam, providing that civil transactions which contravene social ethics shall be invalid, and social ethics are "common standards of conduct as between persons in social life, which are recognized and respected by the community". Thus, social ethics, or social morals is an unwritten rule about what society considers acceptable.
} 
specialized laws are not yet synchronized; not to mention the state agencies and their officials can do only what is allowed by law. The difference among laws remains as an issue for Vietnam legal framework at the current time.

The LCA adopts the principle of due process in international law of dispute settlement: "parties in dispute shall have equal rights and obligations" (Article 4.3), as the same to the Model Law. This ensures both State or Stateowned enterprises and individuals, organization or private enterprises shall receive fair treatment through the judicial system, and that no party has priority beyond the other before the law.

Next, the LCA stipulates that dispute resolution by arbitration shall be conducted in private unless otherwise agreed by the parties (Article 4.4). It mentions the private feature of arbitration but not yet the comprehensive confidentiality principle since there is no rules regarding the parties' obligation to each other not to disclose information concerning the arbitration to the third parties and the arbitrators' like obligations. Finally, an arbitral award shall be final (principle of finality) (Article 4.5).

\section{Jurisdiction of arbitration:}

For the first time since the Ordinance 2003, the use of arbitration in dispute settlement in Vietnam legal framework has been expanded by the LCA 2010. Pursuant to the Ordinance on Arbitration in 2003, disputes under the jurisdiction of arbitration shall be within the scope of "commercial activities". As the interpretation of the term 'commerce' in the Ordinance is not unified throughout the implementation, the jurisdiction of arbitration is limited to listed activities in the Ordinance. ${ }^{73}$ Afterwards, the LCA does not name exhaustive

\footnotetext{
${ }^{73}$ Pursuant to Ordinance on Arbitration 2003, Article 2.3, "commercial activities" are one or more commercial activities of individuals, organizations, including sale and purchase of goods, providing services, distribution, representation, acting as agents, rent, leasing, leasing-purchase, consultancy, construction, engineering, licensing, investment, banking and finance, insurance, exploration and exploitation, transport of goods, passengers by airway, by sea, by railway, by road and other commercial activities in accordance with laws.
} 
types of commercial activities. The jurisdiction of arbitration shall include disputes that arise from commercial activities or arising between parties at least one of whom is engaged in commercial activities ${ }^{74}$. The interpretation of 'commercial activities' shall be referred to the domestic Commercial Law 2005 which are "all activities of profit-making purposes, including, inter alia, sale and purchase of goods, service provider, investment and commercial promotion" " . The abolition of a listing method according to the Ordinance on Arbitration is to avoid misunderstanding that arbitration only has its jurisdiction with respect to listed commercial activities and to extend legal framework for activities of arbitration in Vietnam. The broad scope of commercial activity helps enlarge the use of arbitration agreement in business contracts. The LCA then is in conformity with other specialized laws while they also provide for concerned parties to choose arbitration as a mode of dispute resolution relating to the relating fields. For example, the Investment Law 2014 (Article 14), Construction Law 2014 (Article 146), Securities Law (Article 131), etc. During the arbitration proceedings, the arbitration tribunal has authority to verify facts, collect evidence and summon witness if necessary to resolve the dispute in impartial way.

\section{Qualifications of arbitrators:}

Regarding the compulsory requirements set in Article 20 of LCA, an arbitrator must have: (i) full civil legal capacity as prescribed in the Civil $\operatorname{Code}^{76}$; (ii) a university qualifications in law and at least five years working experience in conformity with education. In special circumstances, specialists with profound expertise, high qualifications and considerable practical

\footnotetext{
${ }^{74}$ Article 2, LCA 2010

${ }^{75}$ Article 3.1 of the Commercial Law 2005

${ }^{76}$ Vietnam legal system is inherited from the French civil law back in history. Vietnam Civil Code provides the legal status, legal standards for the conduct of natural and juridical persons; the rights and obligations of natural and juridical person regarding personal and property rights and obligations in civil relations (Article 1, Civil Code No. 91/2015/QH13)
} 
experience may still be an arbitrator notwithstanding he/she does not have a bachelor degree. Moreover, any person who is currently a judge, prosecutor, investigator, enforcement officer or any official of a judgment enforcement agency is excluded from being an arbitrator. These compulsory requirements are not strict even though it serves as the minimum. An arbitration centre in Vietnam may stipulate higher qualifications as applicable to arbitrators in its own institution.

Ethical standards of an arbitrator are addressed in the LCA. An arbitrator shall not be competent to resolve a dispute and be replaced in the following circumstances: "(a) The arbitrator is a relative or the representative of a party; (b) The arbitrator has an interest related to the dispute; (c) There are clear grounds for considering that the arbitrator is not impartial or objective; (d) The arbitrator was a mediator, representative or lawyer for either of the parties prior to the dispute being brought to arbitration for resolution, unless the parties provide written consent." 77

\section{Establishment of arbitration tribunal:}

The number of arbitrators in a tribunal is not limited but depends on the agreement of the parties. If the parties do not have any agreement on the number, the tribunal shall consist of three arbitrators. ${ }^{78}$

Unless the arbitration centres provide their own procedural rules differently, the respondent shall have 30 days from the date of receipt of the claim and the request to select an arbitrator as sent from the arbitration centre, to make a selection of arbitrator for the respondent and then must notify the arbitration centre. The respondent can also instead request the chairman of the arbitration centre to appoint an arbitrator. Within 15 days after being selected, the arbitrators representing either party shall elect another third arbitrator to be a

\footnotetext{
${ }^{77}$ Article 42, LCA 2010

${ }^{78}$ Article 39, LCA 2010
} 
chairman of the arbitration tribunal. If the respondent has failed to do all of the above, then within a further 7 days after expiry of the time-limit, the chairman of the arbitration centre shall automatically assign an arbitrator for the respondent as well as appoint the chairman of the tribunal.

\section{Defence}

A feature of Vietnam law of arbitration is that the burden of proof is on the respondent. The respondent has the chance to 'defence' themselves prior to the hearings by sending a statement of defence to the arbitration centre within 30 days from the date of receipt of the claim ${ }^{79}$. In the case of ad hoc arbitration, unless otherwise agreed the parties, the defence shall be sent to the claimant. The defence statement consists of supporting grounds and evidence to prove against the claim, or specified allegations in case the respondent finds that the dispute is outside the jurisdiction of arbitration, or the arbitration agreement is void or incapable of being performed. Besides defending himself, a respondent can make a counter claim against the claimant on issue relevant to the dispute. A statement of defence is a chance for the respondents to protect themselves and might save time going into hearings before it happens. If there is not defence submitted, the arbitration proceedings still continue.

\section{Enforcement of arbitral awards}

An arbitral award shall be final and shall be of full force and effect as from the date of its issuance, normally immediately be issued in the session or no later than 30 days from the end of the final session ${ }^{80}$. Firstly, the enforcement of the arbitral award depends on the willingness of the parties. Then if the award debtor does not voluntarily carry out the award or requests the award to be set aside, the award creditor can seek help from the competent civil judgment

\footnotetext{
${ }^{79}$ Article 35, LCA 2010

${ }^{80}$ Article 61, LCA 2010
} 
enforcement agency to enforce such award ${ }^{81}$. Notably, despite the name of Law on Commercial Arbitration, the recognition and enforcement of foreign arbitral award is not governed by this but by the law on enforcement of civil judgement, ${ }^{82}$ which will be discussed subsequently.

The award is final and there are no appeals hearing but the award can be set aside by the court under certain circumstances:

There was no arbitration agreement or the arbitration agreement is void ${ }^{83}$;

The composition of the arbitration tribunal was [or] the arbitration proceedings were, inconsistent with the agreement of the parties or contrary to the provisions of this Law.

$>$ The dispute was not within the jurisdiction of the arbitration tribunal; where an award contains an item, which falls outside the jurisdiction of the arbitration tribunal, such item shall be set aside.

The evidence supplied by the parties on which the arbitration tribunal relied to issue the award was forged; [or] an arbitrator received money, assets or some material benefit from one of the parties in dispute which affected the objectivity and impartiality or the arbitral award.

The arbitral award is contrary to the fundamental principles of the law of Vietnam $^{84}$

One of the grounds to challenge the arbitral award before the Vietnamese court is "violation of fundamental principles of Vietnamese laws" which is a deviation of the concept of "public policy" as provided in Article 34 (2) (b) (ii) of the Model Law.

\section{b. Civil Procedure Code of Vietnam and substantive laws}

As arbitration agreement is considered as a special "civil transaction", it

\footnotetext{
${ }^{81}$ Article 65 and article 66, LCA 2010

${ }^{82}$ Article 67, LCA 2010

${ }^{83}$ See Article 18, LCA 2010

${ }^{84}$ Article 68, LCA 2010
} 
is inevitable that the Civil Procedure $\operatorname{Code}^{85}$ (CPC) applies to govern certain aspects of arbitration agreement, especially its interpretation. In other words, the LCA stipulates the organization and operation of foreign arbitration in Vietnam but the procedures for recognition and enforcement of foreign arbitral award are regulated under this Code, rather than in LCA since the award of foreign arbitrators, civil judgement or decisions of foreign courts belong to civil matters.

According to Article 423, foreign arbitral award shall be recognized and enforced in Vietnam if the foreign country is a signatory to an international treaty about recognition and enforcement of foreign arbitral award together with Vietnam (for example, the New York Convention 1958). In case the foreign country is not a signatory to such international treaty together with Vietnam, foreign arbitral award shall be recognized and enforced on the basis of principle of reciprocity.

The competence to resolve the recognition of foreign arbitral awards belongs to the provincial court (Article 37, para1.b CPC 2015) and may choose one of three places: 1) Place of residence or work of the foreign award if the person against whom enforcement is sought is an individual; 2) where the party on whom the award is enforced is headquartered, if the person against whom enforcement is sought is the agency or organization; or 3) Place of property related to the enforcement of foreign arbitral awards (Article 39, para2.f CPC 2015).

The award creditors have 3 years since the day the foreign arbitral award takes legal effect to submit their application to Vietnam's Ministry of Justice (MOJ) or to a competent Vietnamese Court as specified in the Code, according to provisions of International treaty to which Vietnam is a signatory in order to

\footnotetext{
${ }^{85}$ The Civil Procedure Code No. 92/2015/QH13 (CPC 2015) is a Law passed by National Assembly of Vietnam, providing for the basic principles in civil proceedings; the order and procedures for settling civil cases and matters and enforcing civil judgements/ decisions of foreign Courts, award of foreign arbitrators. See Article 1, CPC 2015.
} 
request the Court to recognize and enforce such award (LCA Article 451). This timeline does not cover the duration of any force majeure event or objective obstacle resulting in the failure of the enforcer to file the application in time. The submitted application at a competent Vietnamese court to be considered does not mean that Vietnam's court will conduct a re-trial over the dispute where the foreign arbitral award has been rendered. The court is only entitled to check and revise the foreign arbitral award and accompanying papers and documents with this Code's provisions, other relevant domestic law provisions and International treaties to which Vietnam is a signatory to have a basis for the issuance of decision to recognize and enforce such award.

The CPC ensures the right to appeal the Court decisions of involved parties. Both awards creditors and award debtors can challenge the decisions of the court regarding recognition and enforcement the foreign arbitral award. The time limit for making an appeal is 15 days from the date the court makes the decision. Once a party appeals the decision, the Collegial People's Court of Vietnam must review the decision under the provisions of this Code (LCA Article 426).

\section{Figure 3.1 Procedures for recognizing foreign arbitral awards in Vietnam}

Step 1: Submit applications

Step 2: Preparation for consideration of applications
Within 03 months: Awards creditors submit applications for recognition and enforcement

Within 05 working days: MOJ forwards the application and the enclosed documents to the competent courts.

Within 05 working days: Court considers, accept the dossiers and notify in writing to judgment creditors, judgment debtors or their lawful representatives in Vietnam, the Procuracies of the same levels and the MOJ.

Within 02 months from the date of acceptance, the Court shall issue $\mathrm{a}_{4}$ decision to: 


\begin{abstract}
After Vietnam's Appeals
decisions on recognition

Courts have made and enforcement of foreign arbitral award, the award shall be legally effective like an effective decision of Vietnamese Court and enforced according to procedures for enforcement of a civil judgement (Article 427). Article 459 of the CPC provides the same exceptional circumstances for recognition of foreign arbitral award as in Article V of the New York Convention which will be discussed afterward.

In short, the Supreme People's Court is now under the process of reviewing and amending the $\mathrm{CPC}$ and in the latest draft of amendment, the provision on the burden of proof has been supplemented. Nevertheless, there is still no clear indication of which principles would be considered as "fundamental" and thus still be left as a huge gap in the arbitration law of Vietnam.
\end{abstract}

Apart from the primary statutes LCA 2010 and CPC 2004, other laws and substantive laws that stipulate arbitration proceedings include:

- The Law on Enforcement of Civil Judgments in 2008 (LECJ): detailed provision dealing with the enforcement of both domestic and recognised foreign arbitrations awards.

- The Governmental Decree No. 63/2011/ND-CP on detailing and guiding certain articles of the LCA on arbitral institutions. 
- The Resolution No.01/2014/ NQ-NDTP: After 4 years since the LCA came into effect, Vietnam Supreme People's Court issued the Resolution No.01/2014 as a guiding document for the implementation of the LCA. Overall, the Resolution brings up more interpretations for the LCA.

$\circ$ provides interpretation on validity of arbitration agreement and grounds for setting aside arbitral award (Article 3,4,7)

o provides strict and narrow interpretations of grounds for annulment of arbitral award (Article 14,15)

- clarifies the supervisory and supporting role of domestic courts and

o defines the supervisory and supportive role of national courts towards foreign arbitration seated in Vietnam (Article 2,5)

- limits the vague "fundamental principles of Vietnamese laws" to "basic principles on conduct, whose effects are most overriding in respect of the development and implementation of Vietnamese law" or "interests of the government and the legitimate rights and interests of one or both parties or of third party", and

- Clarifies the procedures for ad hoc arbitration in Vietnam under the support of local courts; etc.

\section{Treaties}

\subsection{The New York Convention 1958 and Vietnam's accession}

A fundamental feature of dispute settlement by arbitration is a respect to party autonomy accompanying the independence in choice making of the parties such as the choice of arbitrators and applicable laws. Moreover, arbitral award, after all, are not a judicial judgement that rendered by domestic court with a permanent judicial body to make sure the judgement is enforced or to apply sanctions otherwise. Especially with the element of 'foreign', it is inevitable that an award debtor wants to avoid his obligation or compensation to the award 
creditor due to a foreign arbitration other than a country where the award's recognition and enforcement is sought. Therefore, arbitral awards are not always enforced by all parties, especially when parties are from countries that have not been a signatory of a multilateral or bilateral treaty on this matter. The New York Convention is established to serve for this purpose, which is improving such non-recognition and poor enforceability of foreign arbitral awards across borders.

The New York Convention on Recognition and Enforcement of Foreign Arbitral Awards was adopted by the United Nations in 1958. Up till now, it is the most major multilateral international treaty provides for procedures for the recognition and enforcement foreign arbitral awards and also be a profound base for international arbitration system. There have been over 140 nations around the world adhered to and participated in the convention, including the United States, state members of the European Union, and other trading states from Latin American, African, Asian and Middle Eastern.

The Convention regulates contracting states to recognize foreign arbitral awards, i.e., arbitral awards made in the territory of another (Contracting) State as binding and enforce them in accordance with the rules of procedure of its territory (Article I and III). An award creditor who seeks enforcement of a foreign award must submit to the court the arbitral award and the arbitration agreement (Article IV). An award debtor can object to the enforcement by submitting proof as grounds for refusal of enforcement (Article V). The grounds for court's refusal of recognition or enforcement of an award are:

The parties have no legal capacity to enter into an arbitration agreement according to the applicable law or the arbitration agreement is invalid under the referred law.

There is a breach of due process in which the party against whom the award is invoked is not properly notified of the appointment of arbitrator(s) or cannot present the case due to a certain reason. 
> The award is rendered in respect of a dispute that is not anticipated in the terms of the submission to arbitration or goes beyond these terms; or the award covers those matters that are beyond the scope of the submission to arbitration. However, if it is possible to separate parts of the ruling that fall within the terms of reference from those that fall outside the terms of reference, these parts may be recognised and enforced.

$>$ The composition of the arbitral tribunal or in arbitral procedure is not in conformity with the agreement of the parties;

$>$ The award is not yet binding or suspended or set aside in the country of origin;

Furthermore, the court may on its own motion refuse enforcement (Article V.2) if:

$>$ The court finds that the subject matter of the dispute cannot be settled by arbitration pursuant to the laws of that country; or

$>$ The court finds that the award is contrary to the public policy and the law of that country.

In response to the needs to protect the legitimate rights and interests of both domestic and overseas investors and to improve the legal framework in Vietnam, the government of Vietnam has signed the accession to the $1958 \mathrm{New}$ York Convention and became a signatory in 1995. Vietnam made three reservations under the Convention:

- The scope of application of this Convention is to foreign arbitral awards that are made in the territory of another contracting state. In respect of foreign arbitral awards rendered in countries which are not a signatory or participant of the Convention, the convention may be applied on a reciprocity basis.

- This Convention will only be applied to disputes arising out of commercial relations under Vietnamese law. 
- All matters relating to the interpretation of the Convention should comply with the laws of Vietnam.

Finally, the Convention not only focuses on the arbitral awards but also on the arbitration agreements themselves. It provides that a court of a Contracting State, when seized of a matter in respect of which the parties have made an arbitration agreement must, at the request of one of the parties, refer the parties to arbitration (the referral by a court to arbitration), unless the said agreement is invalid.

Although the application of the New York Convention in Vietnam has on occasion been shadowed by controversial judicial decisions such as the courts' decision to terminate arbitration proceedings or set aside arbitral awards based on unfounded grounds (which shall be discussed later on), the Convention still ensures the enforceability of foreign arbitral awards and arbitration agreements involving Vietnamese parties.

\subsection{Bilateral Investment Treaties}

Regards international law, arbitration in Vietnam can also be moderated by international investment treaties. Vietnam is a party in 61 BITs and 23 TIPs, where almost all of them leave an option for settling investor-State disputes by arbitration. Generally, entering into BITs serves as a means of encouraging capital investments and investment protection by ensuring that foreign investors/ investments receive fair and equitable treatment as compared to domestic investors/ investments; giving full protection and security to foreign investments; guaranteeing that investments will not be expropriated by the government except for a public interest, and even only after adequate compensation; all meant to attract further investments. Engaging in international treaties leads to raise the awareness of arbitration in Vietnam, preparing for commercial disputes and treaty claims in the international arena. For instance, 
Vietnam has promulgated a co-operational regulation (Decision 04/2014/QDTTg of the Prime Minister dated 14 January 2014) to deal with investment claims as preparation for possible treaty claims in the future. Large number of BITs provides for international arbitration as an instrument of dispute settlement. Depending on the bilateral investment treaty at issue, disputes can be submitted pursuant to the arbitration rules of ICSID, other institutional proceeding rules or the UNCITRAL rules. As long as the bilateral investment treaty is in place, the host state essentially consents to the jurisdiction of the arbitral body, and the investor is free to bring arbitration in any of the arbitral fora mentioned in the treaty.

According to available statistics provided on the Investment Dispute Settlement Navigator ${ }^{86}$, there have been five ISDS cases in which Vietnam is a respondent and that stem out of BITs or Treaty with Investment provision.

Table 3.1.: Cases under BITs

\begin{tabular}{|c|c|c|c|c|}
\hline $\begin{array}{c}\text { Year of } \\
\text { initiation }\end{array}$ & $\begin{array}{l}\text { Short } \\
\text { case } \\
\text { name }\end{array}$ & $\begin{array}{c}\text { Applicable } \\
\text { IIA }\end{array}$ & Summary & $\begin{array}{l}\text { Outcome of } \\
\text { original } \\
\text { proceedings }\end{array}$ \\
\hline 2004 & $\begin{array}{l}\text { Trinh and } \\
\text { Binh Chau } \\
\text { v. Viet } \\
\text { Nam }\end{array}$ & $\begin{array}{l}\text { Netherlands - } \\
\text { Viet Nam BIT }\end{array}$ & $\begin{array}{l}\text { Claims arising out of the alleged } \\
\text { unlawful confiscation of real estate } \\
\text { and other claimants' assets without } \\
\text { compensation, including the criminal } \\
\text { conviction of Mr. Trinh. }\end{array}$ & Settled \\
\hline 2010 & $\begin{array}{l}\text { McKenzie } \\
\text { v. Vietnam }\end{array}$ & $\begin{array}{l}\text { US - Viet Nam } \\
\text { Trade } \\
\text { Relations } \\
\text { Agreement }\end{array}$ & $\begin{array}{l}\text { Claims arising out of the alleged } \\
\text { Government's failure to transfer } \\
\text { certain land rights to claimant's } \\
\text { locally incorporated subsidiary } \\
\text { necessary for the development of a } \\
\text { tourism resort. }\end{array}$ & $\begin{array}{l}\text { Decided in } \\
\text { favour of } \\
\text { State }\end{array}$ \\
\hline 2011 & $\begin{array}{l}\text { Dialasi v. } \\
\text { Viet Nam }\end{array}$ & $\begin{array}{l}\text { France }- \text { Viet } \\
\text { Nam BIT } \\
(1992)\end{array}$ & $\begin{array}{l}\text { Claims arising out of the alleged } \\
\text { Government's closure of a private } \\
\text { nephrology and dialysis clinic in Viet }\end{array}$ & $\begin{array}{l}\text { Decided in } \\
\text { favour of } \\
\text { State }\end{array}$ \\
\hline
\end{tabular}

${ }^{86}$ UNCTAD, (n 12) 


\begin{tabular}{||l||c||c||c||c||}
\hline $\begin{array}{c}\text { Year of } \\
\text { initiation }\end{array}$ & $\begin{array}{c}\text { Short } \\
\text { case } \\
\text { name }\end{array}$ & $\begin{array}{c}\text { Applicable } \\
\text { IIA }\end{array}$ & \multicolumn{1}{|c||}{$\begin{array}{c}\text { Summary } \\
\text { Outcome of } \\
\text { original } \\
\text { proceedings }\end{array}$} \\
\hline \hline & & & $\begin{array}{l}\text { Nam operated by claimant's local } \\
\text { subsidiary. }\end{array}$ & \\
\hline \hline 2013 & $\begin{array}{l}\text { RECOFI } \\
\text { v. Vietnam }\end{array}$ & $\begin{array}{l}\text { France }- \\
\text { Vietnam BIT } \\
(1992)\end{array}$ & $\begin{array}{l}\text { Claims to money for outstanding } \\
\text { payments concerning RECOFI's } \\
\text { participation in a State-run food } \\
\text { assistance programme that provided } \\
\text { food and basic commodities to Viet } \\
\text { Nam when the country faced food } \\
\text { shortages in 1987. }\end{array}$ & $\begin{array}{l}\text { Decided in } \\
\text { favour of } \\
\text { State }\end{array}$ \\
\hline \hline 2014 & $\begin{array}{l}\text { Trinh v. } \\
\text { Vietnam }\end{array}$ & $\begin{array}{l}\text { Netherlands- } \\
\text { Vietnam BIT } \\
(1994)\end{array}$ & $\begin{array}{l}\text { Claims arising out of the alleged } \\
\text { breach of agreement on confidential } \\
\text { terms between Vietnam government } \\
\text { and the investor back in 2006 }\end{array}$ & Pending \\
\hline \hline
\end{tabular}

(Source: UNCTAD database)

Most recently, the case between Trinh Vinh Binh v. Vietnam government which initiated under the Netherlands- Vietnam BIT and conducted under the UNCITRAL Rules is drawing major public attention in Vietnam ${ }^{87}$.

Trinh Vinh Binh is a Dutch - Vietnamese investor whose investment in Vietnam in the late 1980s was alleged to be illegal. Mr. Binh neither registered for enterprise establishment nor investment under the Law on Foreign Investment 1987 of Vietnam. He asked his family to use their names for ownership of the land, houses and a few Vietnamese businesses on paper. He also asked his relatives in Ba Ria-Vung Tau province to make more permanent residences for himself in those localities in order to receive as many land allocation from local authorities as possible. All these incidents are illegal under

87 The following information of the case is sourced from Nghiencuuquocte.net http://nghiencuuquocte.org/2017/09/04/vu-kien-trinh-vinh-binh-vs-chinh-phu-viet-nam/

Nghiencuuquocte.net is a non-political, non-profit project, firstly founded by PhD.Le Hong Hiep, New South Wales university. It is in form of law research blog, aimed at developing an international study resource in Vietnamese and promoting the study and research of international issues in Vietnam. 
Vietnam's law. In 1996, the investor was arrested by the provincial authority for many criminal charges, including violations of regulations on land rights, tax evasion and bribery. He has been convicted of a criminal offense, sentenced to 11 years in prison and all his property was confiscated after two trials.

In 2000, the investor left Vietnam (reportedly fleeing Cambodia), returned to the Netherlands and in 2003 proceeded to sue the government of Vietnam, bringing the case to international arbitration ICSID as provided in Article 9.4 of the Treaty between Vietnam and Netherlands on Encouragement and Reciprocal Protection of Investments (1994). His claim purportedly alleged that he suffered illegal detention, torture and abuse at the hands of state officials, as well as confiscation of assets amounting to more than $\$ 100$ Million (US). Moreover, he claimed that the treatment of Vietnam to his investment breached the BIT between two nations.

An arbitration provision in investment treaty does help foreign investor like Trinh Vinh Binh stand a chance to secure his investment in lawsuit disputes with governments, regardless of the legality in his implementation of investment. Thanks to the arbitration, two parties met up and reached an agreement outside the court, thus the proceeding was terminated at request of parties in 2006. According to some sources, the content of the agreement might stipulate that Vietnamese government approves the exemption of serving $\mathrm{Mr}$. Binh's imprisonment sentence, compensates the investor up to 100 million USD, returns the property to Mr. Binh, and permits him to return to Vietnam for further investment. In return, Mr. Binh withdrew all his suits and did not disclose any of the contents of this agreement.

However, in 2015 Trinh Vinh Binh made a claim against Vietnam again, alleging that Vietnamese government failed to comply fully with the prior 2006 agreement and claimed for 1.25 billion USD. So far there is no official announcement on Vietnam's media or any arbitration institution statistics affirm the result of the arbitration and due to the nature of confidentiality of arbitration, 
details of arbitral proceedings are not disclosed to public.

Based on the claims and developments of the case, we can see that the nature of commercial activity is highly complicated and so are its disputes. In both two times (2003 and 2015), Trinh Vinh Binh did not claim for assets return but for compensation (100 million USD and 1.25 billion USD), showing a wise move from the investor to dodge the issue of legal investment. Arbitration stemmed from BITs with retroactive provision like the Netherlands-Vietnam (1994) give the means foreign investor to protect their investment back in the day even before the BITs came into force. If the rendered arbitral award is in favour of investor, Vietnam government will lose not only large amount of money, but also more important the reputation with the international community. With the pressure from international public and increasing investorState disputes, Vietnam must step up its game in maintaining transparent business environment and confidence from foreign investors. The international treaties to which Vietnam is a contracting state shall play a critical part in both inspiring and forcing state and private entities of Vietnam to acclimatize to arbitration as a method of dispute resolution.

\section{Practice}

When planning to invest abroad, the availability of an effective and transparent justice system is the main factor to increase confidence among investors and create an investment friendly environment, providing greater regulatory predictability and thereby contributing to sustainable growth. Although staying in line with the most fundamental principles concerning arbitration agreement, Vietnam arbitration does contain certain notable peculiarities.

Arbitration has certain advantages and suitable for resolving commercial disputes because commercial activities are always urgent, flexible and quick, however, arbitration has not become a popular choice to Vietnamese investors. 
The number of commercial disputes resolved by arbitration only accounts for $1 \%$ compared to the number of commercial cases registered to the Supreme Court $^{88}$. Vietnamese investors seem not to be aware of the full advantages of arbitration and they are used to going ahead with the traditional way of resolution: coming to the court.

The revision report of a 4-year period of implementation the LCA from Vietnam's Ministry of Justice shows that up to 2015, there are 12 arbitration centres in the country with total of 350 arbitrators. In 2017 that number has risen up to 18 arbitration centres and 471 arbitrators. Nevertheless, among those only the Vietnam International Arbitration Centre (VIAC) resolved for a large major of disputes. In 2016, VIAC receives 155 new registered cases, keeping the upward trend for recent 5 years ${ }^{89}$ (Figure 3.2.) The biggest portion of all disputes that are being settled at VIAC are related to sales contracts which accounts for $34 \%$. The other fields are construction (15\%), banking sector (11\%) and insurance, tax, etc. (Figure 3.3) Based on the structure of administered disputes at VIAC, we can notice that arbitration is being considered and/or encouraged in various sectors of Vietnam's economy and VIAC is a centre that receives and resolves diversified fields of commercial activities. Vietnamese government has issued further substantive laws guiding the implementation of the LCA. The year 2016 was also the first time for VIAC that the portion of domestic cases is over $50 \%$, which further expresses the confidence of the Vietnamese community, especially the FDI sector, for commercial arbitration in VIAC.

\footnotetext{
${ }^{88}$ Ministry of Justice statistics updated to 2015.

${ }^{89}$ VIAC website statistics http://eng.viac.vn/
} 
Figure 3.2 Number of disputes in VIA from 1993 to 2016

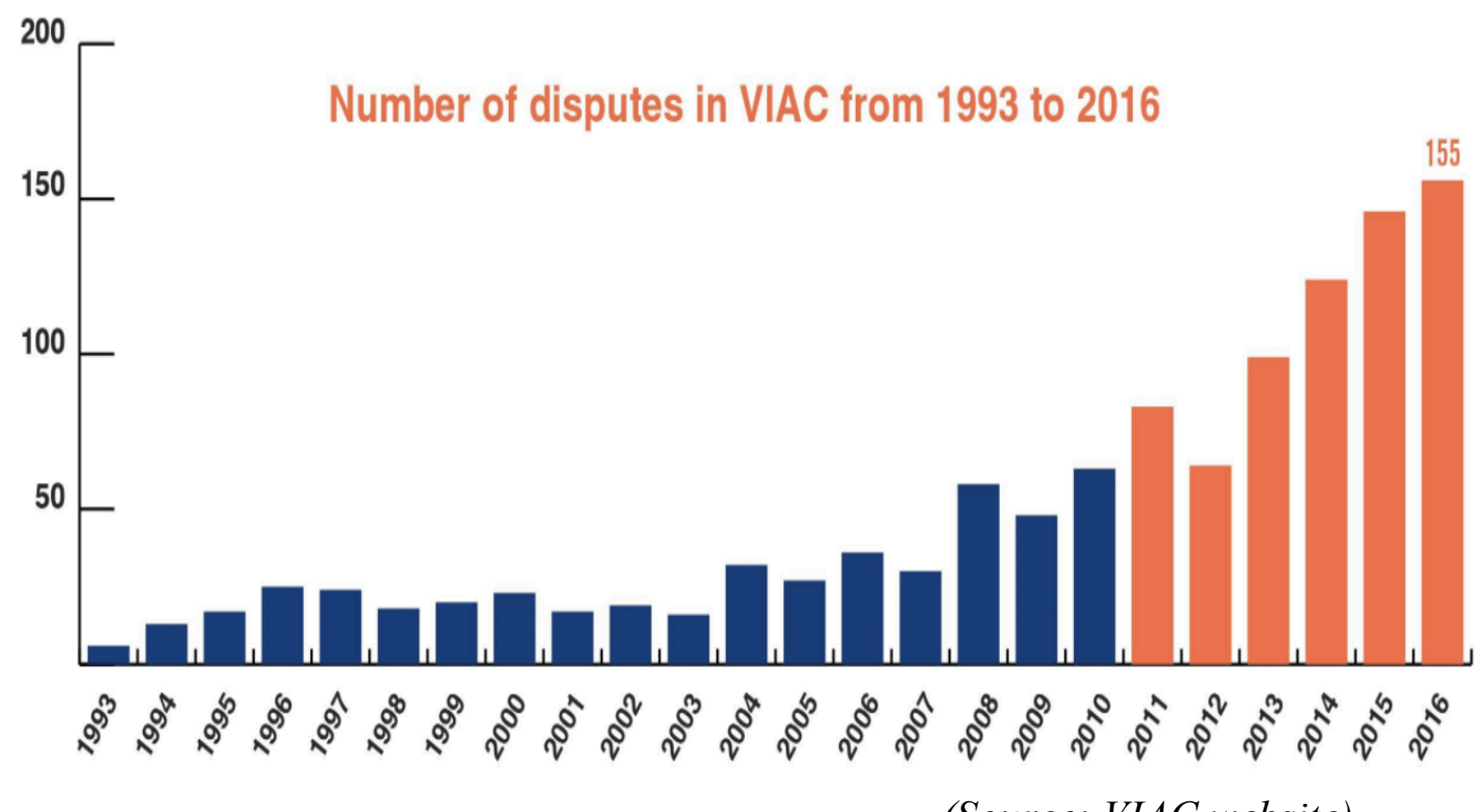

(Source: VIAC website)

Figure 3.3 Types of disputes resolved at VIAC in 2016 


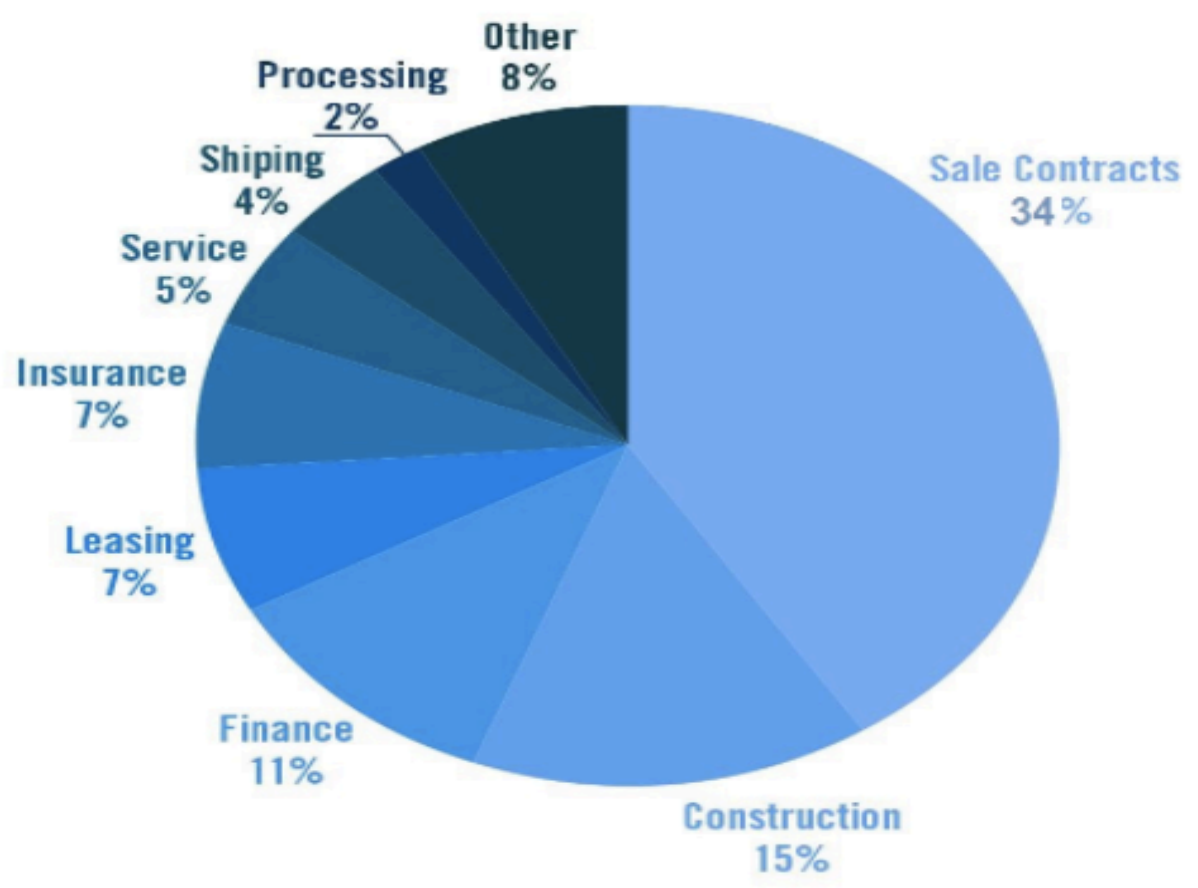

(Source: VIAC website)

At the moment, VIAC is a leading international arbitration organization in Vietnam. It is the only Vietnamese arbitration institution which has being handled cases in diverse fields of commerce and also the only Vietnamese arbitration institution where arbitrating parties having diverse nationalities (Figure 3.4.). The number of disputes involving foreign elements continues to rise with the participation from parties from China, the United States, India, South Korea, etc. Various nationalities involving in the legal proceedings, along with foreign arbitrators from and outside VIAC arbitrators list altogether help confirms its position in Vietnam. This is a positive sign for Vietnam's arbitration. 


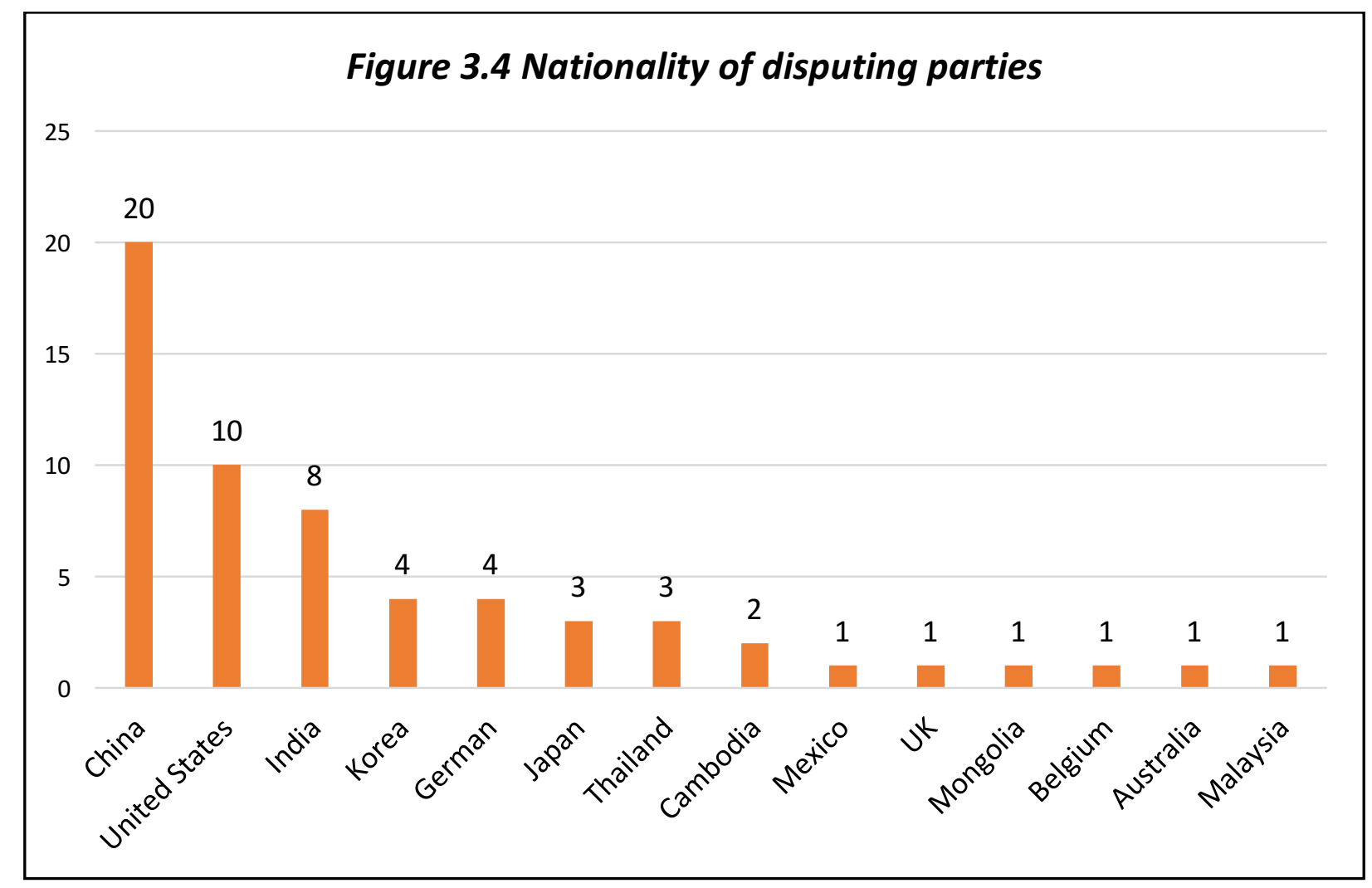

(Source: VIAC)

However, when being asked the reason why enterprise members of the EuroCham especially favour VIAC as a choice of arbitration, they reveal that it is more likely because other dispute settlement mechanisms in Vietnam, such as the Vietnamese courts, have a lot of disadvantages, rather than because of the effectiveness of VIAC arbitration itself. Therefore, the positive statistics reported from VIAC does not reflect thoroughly certain concerns about arbitration practice in Vietnam.

First of all, Vietnamese courts are still not a favoured selection for foreign investors due to the perceived lack of independence of judiciary. According to the World Economic Forum's Global Competitiveness Report ${ }^{90}$, which assesses the competitiveness and drivers of productivity of 137 economies over the world, Vietnam does not achieve high results in Institutions category. Overall, regards to institution, Vietnam ranks 79 out of 137 participating countries in the latest report for period 2017-2018. The Institution

${ }^{90}$ World Economic Forum 2017-2018 (n 48) 
category assesses the country on aspects of governmental regulation and legislation. Three noteworthy indexes that Vietnam ranks consistently low are the limited progress on judicial independence $\left(84^{\text {th }}\right)$; the efficiency of the legal framework in settling disputes $\left(82^{\text {nd }}\right)$ and the strength of investor protection $\left(79^{\text {st }}\right)$. The negative perception of Vietnamese judiciary is also expressed by the remarkably low grades in irregular payments and bribes $\left(109^{\text {th }}\right)$ and transparency of government policymaking $\left(82^{\text {nd }}\right)$ (Figure 3.6). The lack of transparency is for long criticized by foreign investors as judgements of the Vietnamese courts are generally not published or reported and, therefore, investors and their legal advisors do not have access to a body of precedents and case-law that could provide guidance and predictability on the likely outcome of individual disputes. Apart from problems of financing and tax, other major issues for doing business in Vietnam related to governmental offices and bureaucracy. The corruption and policy instability also affects investors' business. (Figure 3.5).

Figure 3.5 Most problematic factors for doing business in Vietnam 


\section{Most problematic factors for doing business}

Source: World Economic Forum, Executive Opinion Survey 2017

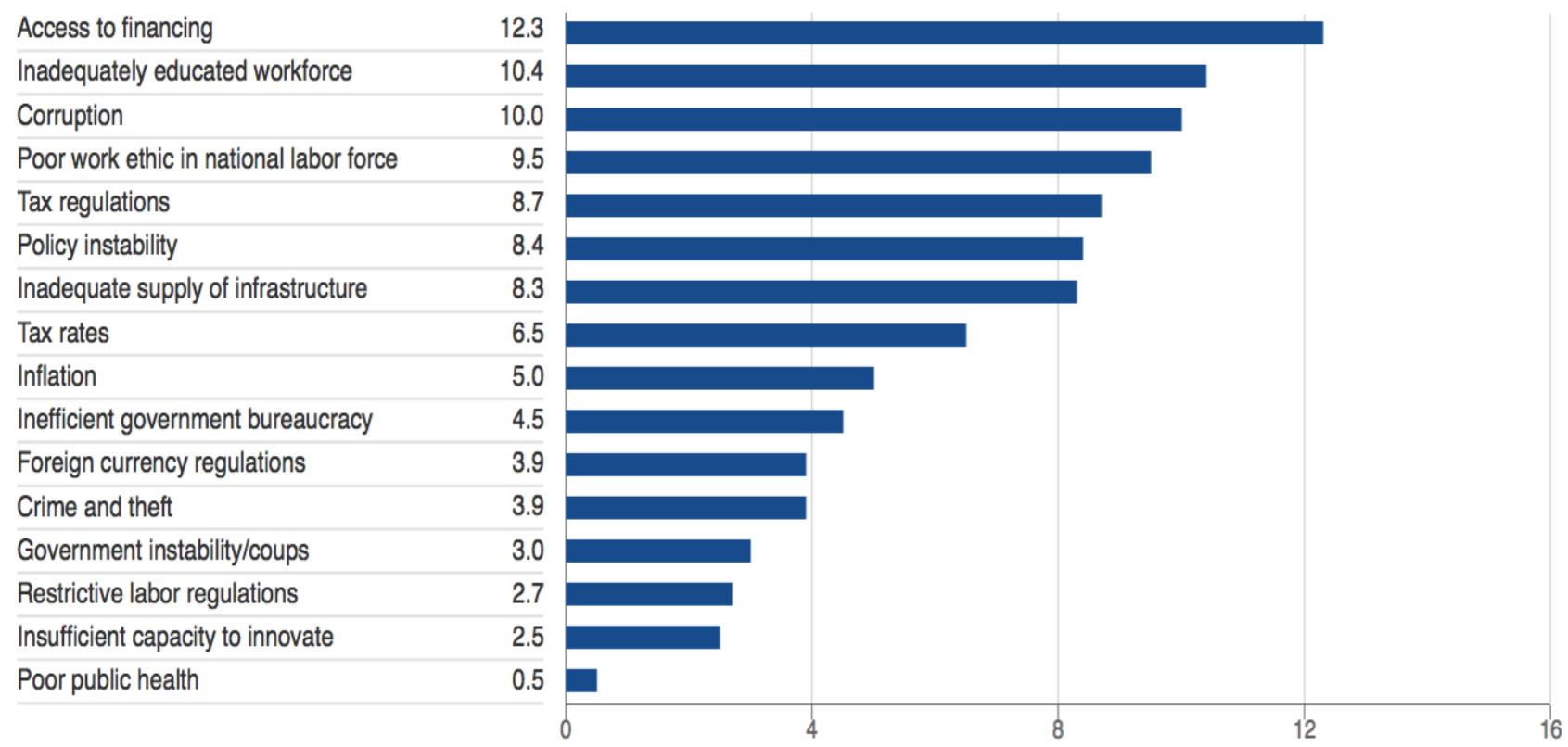

(Source: Global Competitiveness Report 2017-2018)

\section{Figure 3.6 Global Competitiveness index of Vietnam in Institutions 2016}

\begin{tabular}{lrl} 
Index Component & Rank/137 & Value Trend \\
\hline 血 1st pillar: Institutions & 79 & 3.8 \\
1.01 Property rights & 90 & 4.0 \\
\hline 1.02 Intellectual property protection & 99 & 3.6 \\
\hline 1.03 Diversion of public funds & 61 & 3.7 \\
\hline 1.04 Public trust in politicians & 46 & 3.6 \\
\hline 1.05 Irregular payments and bribes & 109 & 3.1 \\
\hline 1.06 Judicial independence & 84 & 3.6 \\
\hline 1.07 Favoritism in decisions of government officials & 56 & 3.3 \\
\hline 1.08 Efficiency of government spending & 69 & 3.3 \\
\hline 1.09 Burden of government regulation & 76 & 3.3 \\
\hline 1.10 Efficiency of legal framework in settling disputes & 82 & 3.4 \\
\hline 1.11 Efficiency of legal framework in challenging regulations & 54 & 3.5 \\
\hline 1.12 Transparency of government policymaking & 82 & 3.8 \\
\hline 1.13 Business costs of terrorism & 60 & 5.3 \\
\hline 1.14 Business costs of crime and violence & 68 & 4.7 \\
\hline 1.15 Organized crime & 69 & 4.9 \\
\hline 1.16 Reliability of police services & 74 & 4.3 \\
\hline 1.17 Ethical behavior of firms & 81 & 3.7 \\
\hline 1.18 Strength of auditing and reporting standards & 115 & 3.7 \\
\hline 1.19 Efficacy of corporate boards & 130 & 3.9 \\
\hline 1.20 Protection of minority shareholders' interests & 98 & 3.7 \\
\hline 1.21 Strength of investor protection 0-10 (best) & 79 & 5.3 \\
\hline
\end{tabular}

(Source: Global Competitiveness Report 2016)

The recognition and enforcement of foreign arbitral awards or foreign 
court judgements cannot be done without the support and guidance from national court. Beside the main LCA governing arbitration in Vietnam with other guiding documents such as the Resolution 01 and Correspondence 246/TANDTC-KT show active role of the national courts toward arbitral activities, especially the role of the Supreme People's Court in the implementation of both arbitration-related legal documents. For example, the court can support the arbitration tribunal in summoning witnesses and collecting evidence (LCA Articles 46, 47, 48). However, how much influence the national court can make over foreign arbitration is open to debate. There are cases that Vietnamese court accepted an unfounded objection from the respondent to the jurisdiction of the VIAC, therefore overturned the VIAC's jurisdiction to the dispute, leading to the dispute settlement proceedings terminated ${ }^{91}$. That is to say a respondent stands a chance to successfully having the court to dismiss an arbitration proceedings by applying an objection to tribunal's jurisdiction. Since there is no right to appeal against the court's decision, the arbitration proceedings can completely stop there. Another example of Vietnamese court's overwhelming intervention to VIAC proceedings is when a court set aside the VIAC's award on the grounds that the arbitration was proceeded in Vietnamese instead of in English as in the arbitration agreement. The award was set aside although the claimant did provide sufficient evidence about the other party's consensus of choosing Vietnamese to arbitrate, and language of the hearing was not a critical factor to the reasoning of the tribunal and validity of the award ${ }^{22}$. Another reason that Vietnamese courts could base on to set aside arbitral awards is 'contrary to fundamental principles of Vietnamese law', which is obviously a vague concept and will be discussed later on.

Examples such as the ones mentioned above tell the story about Vietnamese courts' strong interference in arbitration process which leads to a

\footnotetext{
${ }^{91}$ Eurocham, Trade and Investment Issues and recommendations: Whitebook 2017

${ }^{92}$ EuroCham, Trade and Investment Issues and recommendations: Whitebook 2016,
} 
result that the arbitration proceedings could not take place or the issued award could not be enforced. Currently, some certain progress has been made. In VIAC particularly, during 2015 there were 13 requests to challenge VIAC awards and not one has succeeded. For 2016 (three first quarters of 2016), two requests to set aside a VIAC awards on competence have succeeded before Vietnamese courts. ${ }^{93}$ No further information is available. Among other efforts, Resolution 01 which was issued 4 years after the LCA stresses that the courts shall not reconsider the merits of the dispute to set aside the final arbitral award but may only determine if there is a valid ground to set aside or not as provided in the LCA.

The role of national courts is truly prominent in judicial system. Without courts' recognition and enforcement of arbitral awards, the parties whom the award is enforced on hardly comply with the tribunal decisions. However, it is time for Vietnam judicial system to separate clearer the competency of the court to avoid abuse of authority, and to move towards pro-arbitration with minimum court' intervention. For now, we believe that pressure from foreign business communities and government's efforts to improve the investment environment of Vietnam during the negotiation of free trade agreements may also be additional driving forces for positive changes in the near future.

\section{Part 4. Assessment the compatibility of EVFTA investment court with Vietnam domestic laws}

The Sub-section 3, Section 3 (Resolution of Investment disputes) in Chapter 8 are in fact just one of Vietnam's commitments on investment in EVFTA. Beside ISDS mechanism, other categories of commitments on investment include: investment liberalization principles; investment protection principles; and schedule of market access commitments. The EU, as a top

${ }^{93}$ VIAC (n 89); and Eurocham 2017(n 91) 
foreign investor in the world, surely wants to set up demanding protection for their investors in Vietnam via a new-generation FTA like the EVFTA which is considered to be higher than levels under the WTO. The WTO Dispute settlement mechanism is a system to resolve dispute between two states which means an individual investor cannot submit a direct claim against a State to the tribunal system. In 2015, EU's outward FDI to Vietnam was 0.7 billion€ FDI flows and 5.7 billion ${ }^{94}$ of FDI stocks, making EU one of the largest investors in Vietnam. In return, Vietnam's FDI to EU is much less, with only 0.2 billion€ of FDI stocks, showing that Vietnam investment is not well-equipped to access this large market. Thus, Vietnam certainly desires to attract more investment from this key investor initially and maintain a certain investment environment for its domestic investors as well. With such wide coverage and high commitments levels on investment, especially with the newly introduced ICS as replaced traditional ISDS arbitration platform, it is inevitable that Vietnam's legal framework and investment activities between the two Parties are going to have a significant impact in the upcoming time. Therefore, with respect to EVFTA commitments on investment and altogether putting under a new investment dispute settlement mechanism, Vietnam seriously need to adjust its legal framework in order to conform and enforce its obligations. This part of the paper will serve the purpose of reviewing Vietnam's current legal framework in the light of the specific commitments to the new ISDS system under the EVFTA that the group of author believe to be a necessary step at this period. We are sure that up to this moment, this kind of review is already carried out by responsible government authorities such as Ministry of Investment and Planning (MIP) or Ministry of Justice (MOJ), as a part of Vietnam's process of negotiation and preparation prior the Agreement coming into force. We are aware that the Vietnam Chamber of Commerce and Industry (VCCI) had

\footnotetext{
${ }^{94}$ Statistics from European Commission website with date of retrieval: 15/02/2017 http://ec.europa.eu/trade/policy/countries-and-regions/countries/vietnam/ http://trade.ec.europa.eu/doclib/docs/2006/september/tradoc 111584.pdf
} 
conducted a report "Review Vietnam's legal framework against commitments under the EVFTA on investment" ${ }^{\prime 95}$. Nevertheless, this public report is yet subjective and sketchy since it delivers perspective of domestic firms solely. This paper is expected to bring a perspective that is more balanced between Vietnam's and the EU's point of view - the two parties of the Agreement.

Given the coverage of this review including:

(i) Vietnam's commitments to the regulations of ICS in the EVFTA: mainly focused on Sub-Section 3, Section 3 Resolution of Investment Disputes, Chapter 8 Investment of the EVFTA.

(ii) Vietnam's legal framework of recognition and enforcement foreign arbitral awards,

we hope to give detailed comparisons between Vietnamese legislation and practice on the issue versus particular obligations about ICS, assessing the situation and to see if Vietnam's legal framework is compatible with EVFTA regulations on ICS or not, thereby contributing suitable proposals of adjusting the legal system in conformity with the ICS in the next part of this paper. To analyse the compatibility between Vietnam legal framework of arbitration and the ICS under EVFTA, the relevant articles shall be categorized as follows.

\section{Scope and definition: Article 1 (Scope), Article 2 (Definitions)}

On the surface, we can see that since the ICS is now introduced to Vietnam for the first time; there is no system of standing arbitration court for investor-State disputes in Vietnam, particularly between EU investors and Vietnam government. Thus, there is no domestic regulations in Vietnam law regulate such standing body, and there are no codification of scope (Article 1) of the ICS mechanism between EU and Vietnam and of all definitions of terms

\footnotetext{
${ }^{95}$ Vietnam Chamber of Commerce and Industry (VCCI), July 2016, Report Review Vietnam's legal framework against commitments under the EVFTA on investment: http://wtocenter.vn/publication/reviewing-vietnamese-laws-and-regulations-against-evftacommitments-investment
} 
(Article 2) in the agreement existed in Vietnam laws which are relevant to define the coverage of disputes which are applicable for ICS, as well as the definitions of subjects whose right to proceed in accordance with that coverage are very essential (like the definitions of investor and investment?). These articles needed to be included in Vietnam legal system for instance in form of a part of a suggested Law that guides the implementation of the Agreement.

Vietnam has the Law on Conclusion, Accession and Implementation of Treaties (Law No.41/2005/QH11) or known as the Treaty Law 2005 which contains detailed provisions on implementation of treaties in Vietnam. According to the Treaty Law 2005, treaties may be applied directly as long as they 'explicit and specific enough for implementation' or Vietnam government may 'decide or propose to amend, supplement, cancel or promulgate legal documents for the implementation of the treaty ${ }^{96}$. In other words, treaties that are not clear enough for direct implementation would be incorporated into the domestic systems via specific legislation ${ }^{97}$. In the case of EU-Vietnam Free Trade Agreement, the section of ICS is clear enough to apply directly; however, it is ideal to have further guidance from the government about implementation of the agreement.

Submission of a claim and conditions precedent: Article 7 (Submission of a claim); Article 8 (Other claims); Article 9 (Procedural and Other Requirements for the Submission of a Claim); Article 10 (Consent); Article 11 (Third Party Funding)

\footnotetext{
${ }^{96}$ Article 6.3, the Law on Conclusion, Accession and Implementation of Treaties (Law No.41/2005/QH11) http://moj.gov.vn/vbpq/en/lists/vn\%20bn\%20php\%20lut/view detail.aspx?itemid=5509

${ }^{97}$ Lan Ah Nguyen, Hao Duy Phan and Jessye Freeman, International and ASEAN Law in the ASEAN 10 National Jurisdictions: The Reception of International Law in the Legal System of Vietnam, Centre for International Law (CIL) Working Paper.

https://cil.nus.edu.sg/wp-content/uploads/2016/08/SD ES-ASEAN-10-Vietnam-study.pdf
} 
Article 7 and Article 9 in Sub-Section 3 gives guidance on the procedure to submit a claim. At first, alternative dispute resolutions (ADR) are always encouraged. If ADR such as mediation and consultation do not settle the dispute, the claimant may notify the Party of its intent to bring a claim ${ }^{98}$ (within 6 months since submission of request for consultations - this period is also a prerequisite for claim submissions). Initially the claimant shall deliver a notice of intent, sent to the EU or to Vietnam as the case may be. After three months since the notice of intent, the claimant submits the claim to the Tribunal under one of a number of sets of arbitration rules: ICSID Rules, ICSID Additional Facility Rules, and the UNCITRAL Arbitration Rules. In this context, for European investors in Vietnam and for Vietnamese investors in Europe, the ICSID Rules are not available as neither Vietnam nor the EU is a member of ICSID Convention, so the UNCITRAL Rules or ICSID Additional Facility Rules can be used. This is also a considerable point in Vietnam's current legal framework regards to the implementation of its commitments to any type of IIA with other countries as well. In the near future, Vietnam should consider pursuing ICSID Membership, given the popularity of the ICSID Rules and the long-established of the ICSID. The ICSID and ad hoc arbitration under UNCITRAL rules have always been the most frequently proposed fora in $\mathrm{BITs}^{99}$.

Furthermore, the consent of EVFTA Parties in Article 10 is explicit and confirms the commitments of compliance from Vietnam. ${ }^{100}$ If this protocol of submission starts coming into use, Vietnam needs a clear system to manage and

\footnotetext{
${ }^{98}$ Article 6, Sub-Section 3, EVFTA

${ }^{99}$ OECD, Dispute settlement provisiosn in international investment agreements: A large sample survey, Organization for Economic Co-operation and Development Investment Division, Directorate for Financial and Enterprise Affairs.

http://www.oecd.org/investment/internationalinvestmentagreements/50291678.pdf

${ }^{100}$ Notably, Vietnam has five years after the entry into force to ensure the ICSID-equivalent enforcement regime. During the transitional 5-year period, Viet Nam does have an international obligation to enforce arbitral awards by virtue of the New York Convention (Article 10).
} 
oversee the compliance of all claims brought against Vietnam, which is what Vietnam currently lacks. The Ministry of Justice (MOJ) and the Ministry of Planning and Investment of Vietnam (MPI) are the two most competent and relevant authorities in this issue. At the moment, there is yet faint cooperation between these two governmental bodies - judicial and executive - in oversee the claims of ISDS cases. At the same time, there has not been any governmental gate information to provide information and records of claims and disputes to public. Finally, Article 8 basically helps to prevent that a single claim is being addressed by multiple courts. To comply to this procedure, in the future the MPI is supposed to support the MOJ in keeping track of the claims and checking its compliance.

Another important part in dispute settlement process is finance, and thirdparty funding is becoming an integral part of arbitration in modern time. For many reasons disputing parties, especially claimants, wish to gain financial support for their arbitration process; they may want to minimize the risk, to reduce legal budgets, or to take the cost to pursue litigation off-record. The third party must be a natural or judicial person who is not a party to the dispute. This third party may make an agreement with a disputing party to finance wholly or partly cost of the proceedings, and in return they expect to get 'a remuneration dependent on the outcome of the dispute or in the form of a donation or grant ${ }^{101}$. From this definition of 'third party funding' we can anticipate that main users of third party funding are claimants, funders, funding brokers, or law firms. Article 11 of the ICS allows disputing party to get third-party funding, but emphasizes that the funding must be informed timely to the other Party and the Tribunal. Vietnam government and Vietnamese investors just need to pay attention to this rule of time, and take full advantage of a possibility of financial help in their dispute settlement process. However, we think that an important point which is not mentioned in the Article 2 Definition of Third-Party Funding

${ }^{101}$ Article 2, Section 3, Chapter 8, EVFTA 
is about the control and conflicts of interests of the third-party funder. It is impossible that a funder might want to control an arbitration to some extent (such as time, seat of arbitration, etc.) via his financial influence. However, as this is a permanent standing court, this possibility should not be a worry. On the other hand, a chance of hidden conflicts of interests can exist, which leads to the fact that the claimant is encouraged and backed-up to submit a lot of frivolous claims. In the future, Vietnam's Government, along with the MOJ and MPI, should consider making investigation on the profile of third-party funder of EU investors if necessary.

\section{Investment Tribunal System: Article 12 (Tribunal); Article 13}

\section{(Appeal Tribunal); Article 14 (Ethics)}

In this subsection, significant features about the operation of investment tribunal system are provided. Overall, this system of investment dispute resolution is novel for Vietnam. There is a standing panel for each instance, the disputing parties' choice of decision maker is replaced with an administrative assignment of panel members, and especially the availability of a second (appellate) instance to review the legal analysis of a final Tribunal report. Looking at Vietnam legal framework, current practices shall definitely fall short of EVFTA commitments to this new ISDS mechanism unless Vietnam has set certain rules as guidance for implementation. The ICS in EVFTA is not yet recognized in Vietnam domestic law. Even though according to VCCI's report, this parallel existence does not affect domestic legal system, it is a very subjective opinion ${ }^{102}$. The fact that the ICS in EVFTA does not exist substituting to, but simultaneously with domestic dispute settlement resolution is very challenging for Vietnam once the system goes into force. So far, all arbitral awards shall have to be reviewed again by the domestic court in order to

${ }^{102}$ VCCI (n 95) 
be recognized and enforced. Here the ICS is an external standing body, outside domestic legal system, whose decisions shall not be reviewed by domestic courts and enforced as if it is a judgement of domestic courts (after first fiveyear duration since entry applying the NYC). Thus, we are indeed looking forward to seeing how reality is in the future when the ICS comes into use.

Article 12 and Article 13 descriptively instruct the organizational structure of two panels: The Tribunal and the Appeal Tribunal. In short, Parties choose in total 15 members: 9 Tribunal members and 6 Appeal Tribunal members. Each must select 5 nationals ( 3 for the Tribunal, 2 for the Appeals Tribunal) and together select 5 non-Party-nationals for the two tribunals. The national tribunal member positions are not limited to nationals. All selected Members be on either of the panels must be competent in terms of legal merits and conform to the ethical requirements as set out in Article 14. As stated in part two of this paper, there are three points of requirements of composition of the courts that Vietnam should be concerned about. First, Judges of the ICS must have demonstrated expertise in public international law in order to become eligible. The Agreement does not introduce any criteria to measure and assess such expertise demonstration for judges, whether it is their educational major, their research field, or experiences of involving ISDS cases. Second, there are differences across nations regarding the qualifications for judicial offices. Although the list is nominated by Vietnam, both Parties of the agreement should reach consensus on common qualifications for judicial offices to be nominated to member of the Tribunal system in order to facilitate the appointment process of the Trade Committee afterwards and to have a rather even panel of judges. Finally, the impartiality, fairness and diligence of the judges, as similar to standards of conduct in traditional ISDS mechanism, are once again reaffirmed under EVFTA in the form of a Code of Conduct (Annex...), binding upon the Court. Once appointed into Tribunal and Appellate Tribunal panels, they shall stop any other business, in which their roles are counsels, experts or witnesses, 
that related to either party's new or pending investment disputes under this or any other agreement or domestic law. Vietnam must be extremely cautious to these comprehensive rules and selection criteria of the judges since they deprive parties of the power of influencing the selection of the judges seating on the Court and tackle the "double hat" issue. Judges must fully aware of their roles and responsibilities to represent the rights of their country in this critical arbitration system.

Furthermore, both Tribunal and Appeal Tribunal will draw up their own Working Procedures and adopt it for implementation. While either tribunal could rely on arbitration rules chosen by the investor, the fact that the Appeal Tribunal is the first such institution means that there are no pre-existing rules on which it could rely. ${ }^{103}$

From the start, we can see that the role of MOJ is extremely indispensable and so is the MPI's. Regarding the selection of Vietnam's proposals to the Trade Committee the composition of Tribunal systems, the MOJ can check the legal qualifications of nominees as they are knowledgeable about qualifications required in Vietnam for appointment to judicial office or "be jurist of recognized competence". On the other hand, MPI can contribute to the judge selection process since the agency can provide experts in the field and they need to cooperate with the MOJ to provide sufficient resources for conducting the search for optimal candidates. As the value of efficiency in dispute resolution is highly valued, investors who are familiar with the specifics of investment arbitration can also support the system.

Applicable law, interpretation and languages: Article 16 (Applicable law and rules of Interpretation), Article 24 (Language of the proceedings)

${ }^{103}$ VCCI (n 95) 
According to Article 16, when rendering a decision, the Tribunals are to apply provisions of the EVFTA along with other general principles of international law applicable between Vietnam and the EU. In terms of interpretation, the Tribunal shall apply customary rules of treaty interpretation of public international law, as codified in the Vienna Convention on the Law of Treaties. If relevant, the tribunal may take the domestic law into consideration and to interpret the domestic law, the Tribunal shall only be bound by the interpretation given by the domestic courts. Therefore, for Vietnam, the MOJ will be responsible for providing the tribunal with precise interpretations of domestic provisions given from Vietnamese courts. Vietnamese government must regulate and assign clearly which courts in the judicial system are competent to interpret Vietnamese law. Vietnam's judicial system comprises of the People's courts system, military tribunals system, and people's procuracies. ${ }^{104}$ In respect of processing investment disputes, People's courts system is the most suitable for the task. But in the People's courts system there are four levels: The Supreme People's Court, the superior people's courts, the provincial-level people's courts and district-level people's courts. But which interpretation should be considered? Should be the interpretation of laws by highest court - the Supreme People's Court? Or should it be the provincial-level courts where the investment agreement was signed, where the representative company of the European investor is based (if any), or where the properties/ investment of the EU investor is held? Many factors must be considered in interpretation domestic law. Not to mention Vietnamese legal framework is in need of urgently comprehensive consolidation.

About language of the proceedings, there is no pre-determined official language of proceedings, as this is to be determined by agreement of the disputing parties or, if they cannot agree, by the Tribunal (Article 24). If the

\footnotetext{
${ }^{104}$ Anh Luu, Le Thi Hanh, February 2017, Vietnam Legal Research http://www.nyulawglobal.org/globalex/Vietnam1.html\# Judicial System
} 
latter, the MOJ must be in charge of negotiation with the claimant about language as they lead the dispute settlement process. It is important to remember that if language of proceedings is unanimously agreed on and whichever the language is, Vietnamese courts must have no intervention on the recognition and enforcement of the arbitral award rendered by the Tribunal. Setting aside a foreign arbitral award on fraudulent ground which is the language of proceedings was inconsistent to what the arbitration agreement between the parties provided for did happen in Vietnam, ${ }^{105}$ not to mention that the language of hearings was immaterial and not decisive factor to the reasoning and validity of the award. This negative record of Vietnam's weak compliance with foreign arbitral award protocol must not be repeated.

Claims management of ICS: Article 33 (Consolidation), Article 17 (Anti-circumvention), Article 18 (Preliminary objections), Article 19 (Claims unfounded as a matter of law)

Basically, the provisions in Article 33 (Consolidation) permits the President of the Tribunal to combine separate claims into a single Tribunal process. In the event that two or more claims submitted arise out of the same events and bear in common a question of law or fact, the respondent may seek for consolidation of such claims by submitting to the President of the Tribunal a request for consolidation and sending the request to each claimant in a claim which the respondent seeks to consolidate. Considering the efficiency and the interest of consistency of awards, the President of the Tribunal shall constitute a new division of the Tribunal who have jurisdiction over all or part of the claims which are subject to the joint consolidation request. This provision is critical under a circumstance when Vietnamese government as respondent is facing a number of claims from EU investors at the same time and arising out of the

\footnotetext{
${ }^{105}$ VCCI Whitebook 2016 (n 92)
} 
same event. By consolidating such claims, government can save time and costs handling each claim one by one. Nevertheless, this demands the MOJ of Vietnam to be substantially efficient in managing claims from EU claimants in order to submit the request of consolidation in time, with detailed evidences to prove the grounds and scope of consolidation request.

Other provisions in Sub-Section 5 indicates the efficiency of claims management is about Anti-circumvention (Article 17); Preliminary objections (Article 18) and Claims unfounded as a matter of law (Article 19). Pursuant to Article 17, The Tribunal shall examine the dispute to check whether the dispute was foreseeable with high degree of probability at the time when the claimant acquired ownership of investment. Upon the basis of facts, if the investment was found out to be acquired for the main purpose of submitting the claim against the host country, despite the predictable loss, the Tribunal shall determine to decline jurisdiction.

The respondent is given a chance to file an objection against a claim which is clearly lacking in legal merit, no later than 30 days after the constitution of the division of Tribunal and in any event before the first session of the division of the Tribunal. The respondent may present arguments to the tribunal to this effect for early decision. Without prejudice to a Tribunal's authority to address other objections as a preliminary question, the respondent may also present arguments to the tribunal for early decision if a claim fails to present a prima facie case. In other words, a claim, or any part thereof, is not a claim for which an award in favour of the claimant may be made even if the facts alleged were assumed to be true, the Tribunal shall decide that claim is unfounded as a matter of law (Article 19).

In order to comply with this group of provisions, Vietnamese government needs to provide the Tribunal with the necessary arguments and evidence timely. Being able to seek for early decisions can help a Party save lots of time and cost in litigation. To do that, the infrastructure and resources for close 
cooperation between the MPI, the MOJ and provincial authorities such as Department of Planning and Investment (DPI) at Hanoi city, Ho Chi Minh city, Da Nang city, etc. need to be securely synchronized so that the relevant information is provided to MOJ in a timely manner. We are not aware of such coordination happened in previous ISDS cases of Vietnam, as information related to Vietnam's ISDS cases from governmental agencies is normally being kept confidential. Local authority will be the helpful force investigating the investment practice which dispute arose out of, providing facts for MOJ to analyse if whether a claim is manifestly without legal merits or unfounded.

\section{Transparency of proceedings: Article 20}

The UNCITRAL Transparency Rules in Treaty-based Investor-State Arbitration will apply to the ICS between Vietnam and the EU. This requires the publication of submissions and rulings, inter alia, of the disputes such as: the request for consultations (Article Consultations), the notice of intent (Article), the notice of challenge and the decision on this challenge (Article Ethics), the request for consolidation (Article). All these documents as regulated under Article 3 of UNCITRAL Transparency Rules shall be made publicly available. A noteworthy point is that UNCITRAL Transparency Rules provides for exceptions to transparency in its Article 7 which are confidential or protected information shall not be made available to the public. Once the ICS comes into force, the rules of transparency must be complied to. This provision is quite a challenge for Vietnam as the country never ranks high in transparency in judicial decision making and lawsuit documents publication. It is common in Vietnam that arbitration proceedings usually take place behind closed doors. At the moment, a public database of the MOJ about claims and arbitration involving foreign investors does not exist. Information that is available to public about ISDS cases between Vietnamese government and foreign investors such as the abovementioned Trinh Vinh Binh case is only via law blogs of legal 
community. With the tradition of secrecy and not-open-to public trials, Vietnam must adjust its practice to comply to ICS commitments in transparency. On the other hand, the MOJ must prepare to be ready to provide any sufficient evidence and legal basis to request for redaction of confidential information since there could be classified government information embraced in the dispute and the government has proper right to reserve it. Furthermore, both MPI and MOJ would benefit from accession to the most current materials in this area. This is also related to Article 21 (Interim decisions). The MOJ shall lead the dispute settlement process and will provide the Tribunal with the essential arguments/ evidence about what the preservation orders are needed.

Roles of involved parties: Article 25 (The non-disputing party); Article 26 (Expert reports); Article 32 (Roles of other parties)

Even though the definition of "non-disputing Party" is explained in Article 2 (Definition) ${ }^{106}$, Section 3 Resolution of Investment Dispute, the role of non-disputing Party seems to be still unclear for both parties of the agreement. The Non-Disputing Party has the right to be notified of the dispute, including receiving from the respondent following documents: a request for consultations, a notice of intent, notice of determination and a claim (Article 25.1 para. a) and any documents upon request in accordance with the rules on transparency. It also has the right to attend a hearing and to make oral statements regarding interpretation of the Treaty provisions.

However, as the nature of the proceedings is a dispute settlement, the role of making interpretive statements about the EU-Vietnam Free Trade Agreement at hearings is yet vague. Perhaps the interpretation of domestic laws is rather

106 "Non-disputing party" means Viet Nam when the respondent is the European Union or a Member State of the European Union, and the European Union when Viet Nam is the respondent (Article 2, Sub-section 1, Section 3, Chapter 8, EVFTA). 
material. Another concern about non-disputing parties making treaty interpretation is the non-disputing party may show prejudice to a disputing party who is its nationals ${ }^{107}$ by making broad and out of scope treaty interpretation, which could be considered a manner 'tantamount' to diplomatic protection. However, before this provision of the EVFTA, Vietnam needs to determine which ministry to act in the role of "non-disputing party" and allocate its competencies promptly.

Last but not least, the role of experts is welcomed to the dispute settlement by the Tribunal since the Tribunal may need advice from experts on factual issue concerning environmental, health, safety or other matters raised by a disputing party in a proceeding (Article 26). However, Vietnam government should bear in mind that requested report from experts would definitely add more cost to the proceedings ${ }^{108}$ and require sufficient budget for this stage.

There is also a provision included to regulate the role of each Party to the Agreement. Accordingly, no home State shall give diplomatic protection to its investor, or bring an international claim as diplomatic assistance for its investor, in respect of a submitted claim unless the other Party has failed to abide by and comply with the award rendered in such dispute (Article 32). However, informal diplomatic exchanges for the sole purpose of facilitating a settlement of the dispute is acceptable. On other hand, either Vietnam or the EU as a party of this agreement can make a claim of a state-to-state dispute settlement under Chapter $\mathrm{X}$ regarding the other Party's measure that is alleged to have breached the

\footnotetext{
${ }^{107}$ Paparinskis, M., \& Howley, J. (2015). Article 5. Submission by a non-disputing Party to the treaty. In M. Wong \& R. Hadgett (Authors) \& D. Euler, M. Gehring, \& M. Scherer (Eds.), Transparency in International Investment Arbitration: A Guide to the UNCITRAL Rules on Transparency in TreatyBased Investor-State Arbitration (pp. 196-226). Cambridge: Cambridge University Press

${ }^{108}$ For greater certainty, the term "costs of proceedings" includes (a) the reasonable costs of expert advice and of other assistance required by the Tribunal, and (b) the reasonable travel and other expenses of witnesses to the extent such expenses are approved by the Tribunal.
} 
Agreement. The MOJ should appoint a responsible ministry, the MOIT for example, to be in charge of investment dispute settlement under the Chapter $\mathrm{X}$ in the EVFTA.

Awards and enforcement of arbitral awards: Article 27 (Provisional Award); Article 28 (Appeal procedure); Article 29 (Final award); Article 31 (Enforcement of award)

The framework of Tribunal decisions is clearly set out via Article 27, Article 28, Article 29 and Article 31. Within 18 months of the date of submission of the claim, disputing parties shall receive a provisional award issued by the Tribunal (Article 27). The award must not include punitive damages but strictly of monetary damages, not exceeding the amount of loss suffered and applicable interest. A noteworthy point in the provision is that all costs of proceedings shall be borne by the unsuccessful disputing party unless the Tribunal decides otherwise and adjust proportionately. However, the exceptional circumstances are not defined, only saying that if the Tribunal finds that apportionment is appropriate and decides case-by-case. Vietnam government must consider all costs incurred in proceedings, including costs of experts report as mentioned above, costs of legal representation and assistance, etc. in order to provide argument to the Tribunal for burden of costs reduction if possible. At the same time, it is advisable for Vietnam to have a calculation and estimation for the maximum amount of costs to contribute to the supplemental rules on fees which shall be adopted by the Trade Committee within a year after the entry into force of this Agreement (Article 27.5).

Disputing parties can appeal the provisional award to the Appeal Tribunal within 90 days for a review of the legal analysis. Otherwise, the provisional award shall become a final one (Article 28, Article 29). The appellant is required to provide security, including the costs of appeal as well as other reasonable amount determined by the Appeal Tribunal. Other provisions which 
related to proceedings including Article 11, Article 20, 21, 23 shall be applied mutatis mutandis in respect of the appeal procedure. The standing panel of Appellate Tribunal for ISDS arbitration is brand new for Vietnam so it is difficult to say beforehand if Vietnam legal framework is compatible with the new system, but we know for sure that Vietnam needs to revise the advisability of an appeal and develop its technical assistance. A tight cooperation and consultation between MOJ and MPI is necessary.

Under the EVFTA, the final arbitral award rendered from the Tribunal or the Appellate Tribunal is binding to each Party and each Party must recognize and enforce it in its territory as if it were a final judgment of its own courts (Article 31). In fact, this provision is in addition to Article 10 (Consent), by which Parties gives consent to dispute resolution proceedings and legally accept the [Appeals] tribunal's decision. ${ }^{109}$ Vietnam will have a period of five years after the entry into force of this Agreement to prepare for compliance fully to Article 31. During this time of transition, the recognition and enforcement of the tribunal's awards in Vietnam shall be governed by the New York Convention (NYC), as well as the LCA, the Resolution 01 and courts of Vietnam. There are, however, a number of legislative changes that will also have to be pursued to bring Vietnamese law into conformity with the obligation of enforcement.

Perhaps this Article 31 about enforcement of awards is the one that poses most concerns among all the clauses about the ICS and plays a weighty role in implementation the agreement between the two parties. Nevertheless, member companies of EuroCham (European Chamber of Commerce in Vietnam) have indicated their concerns about difficulties in achieving the recognition and enforcement of arbitration awards by Vietnamese courts. ${ }^{110}$ In Vietnam, the

\footnotetext{
109 'consent' "implies [...] the disputing parties shall refrain from seeking to appeal, review, set aside, annul, revise or initiate any other similar procedure before an international or domestic court or tribunal, as regards an award pursuant to this Section" (Article 10, Section 3, EVFTA)

${ }^{110}$ VCCI Whitebook 2016 (n 92), VCCI Whitebook 2017 (n 91)
} 
LCA 2010 of Vietnam provides that Vietnamese courts can reject the application of a foreign arbitral award if the award violates fundamental principles of Vietnamese law (Article 68, LCA 2010) but there is no current legal text in Vietnam legal system regulates what "fundamental principles of Vietnamese laws" are.

Later on, the Resolution 01/2014/NQ-HDTP offers a bit more interpretation for the LCA's clause that "the arbitral award contravenes the basic principles of Vietnam's Law" means the arbitral award violates "the effective basic rules for formulation and implementation of Vietnam's Law" (Article 14, d) but this interpretation is rather inadequate. While Vietnam chooses the alternative of "fundamental principle of law", the Model Law and the New York Convention had different approach with the term of "public policy"111. To assess whether an arbitral award is contrary to public policies of a country is possible and clearer than compare against principles of the whole law system. This deviation to the Model Law and the NYC leaves a gap of confusion and sidestep in recognition and enforcement of foreign arbitral awards in Vietnam as well as implementation international treaties regards the same issue. In this regard, Vietnam legal framework falls short of the EVFTA investment court.

Another important issue is the current situation of reversed burden of proof happening in Vietnam which is inconsistent to the NYC provisions. Under the NYC, if the award debtor wants to object to the enforcement of a foreign arbitral award, the award debtor has to provide proof to base his objection. Nevertheless, as analysed in part II, in Vietnam the practice is quite different. It is the award creditor who is required by Vietnamese courts to provide proof to turn down the other party's objection. This practice results in a situation in which the award debtors can raise as many objections as possible,

${ }^{111}$ See Article 34.2 (b) (ii), UNCITRAL Model Law on International Commercial Arbitration 1985; Article V.2 the New York Convention 1985 
even frivolous, in order to stonewall legitimate rights of the award creditor. Most importantly, the recognition and enforcement of foreign arbitral award in Vietnam hardly takes progress unless this practice is improved.

To comply with the EU-Vietnam FTA, the Government of Viet Nam needs to adjust its rules regarding the recognition and enforcement of arbitral awards promptly. It is important to remind that the arbitral awards rendered by the ICS are binding upon Vietnam from day one since the EVFTA comes into force, and the recognition and enforcement shall be conducted pursuant to the NYC in the first five years. In other words, Vietnam has only five years to act and bring its legal framework closer to the international guidelines. After five years, the final arbitral award in respect of disputes where Viet Nam is the respondent shall be binding, not subject to appeal, review, set aside, annulment and enforced as if it were a final judgment of a court in Vietnam itself (Article 31 para.1, para.2).

Considering all divergences above, Vietnam's government should instantly revise and adjust its legal framework to prepare before the treaty going into effect. Not only to prepare for the ICS of the EVFTA, Vietnam's legal framework must also brace up for the future multilateral dispute settlement mechanism as it committed to establish via Article 15 of the EVFTA. Particular recommendations for preparation will be proposed below. 
Part 5. Some recommendations for Vietnam's legal preparation with the EVFTA ahead

\subsection{Legal review}

Modifying from and being based on the existing ISDS arbitration system, the ICS under the EVFTA will be applied in practice for the first time between Vietnam and the EU. As the establishment and operation of the investment court mechanisms with standing bodies Tribunal and Appeal Tribunal are completely outside the scope of application of Vietnamese law, there is no legislative modification or amendments required for these aspects of the ICS. However, there is surely a significant amount of work regarding legal review for Viet Nam to do so as to establish and achieve a smooth operation of this System.

\section{Include a Suggested Law}

From the analysis above, in our opinion Vietnam's legislation is mostly not compatible with the ICS in the EVFTA, or more exactly Vietnam domestic law does not bear any resemblance or not cover the provisions of the ICS. Although this mechanism is not applied for Vietnamese investors against Vietnamese government and does not affect the domestic dispute settlement arbitration procedures, but it is applicable to European investors against Vietnamese government in disputes in accordance with the scope provided for under the EVFTA. Moreover, the commitments in respect to the recognition and enforcement of final awards are totally within the scope of Vietnam's legislation. What Vietnam needs to do now to make the country's legislation compatible with the EVFTA is shortly covering the implementation of commitments to the ICS under the domestic laws in a form of a Suggested Law. 
This Suggested Law may be designed to be about implementation of the EVFTA on Investment as general or separately on the Investment Court System. If the former, the Suggested Law is better off including the interpretation again the coverage and specific terms for the EU partners since some terms are clear and detailed enough to be directly applied in practice but some terms are different. For example, according to the general provisions of EVFTA, a natural person who just "seeks to make an investment" is regarded as "an investor", meanwhile Vietnamese legislation define investor differently. Under Vietnam law, investor means "an organization or individual that makes business investment; investors include Vietnamese investors, foreign investors and foreign invested business organization" ${ }^{\prime 12}$. In other words, a person that has made investments shall be called 'investor' in Vietnam while a person attempts to (not necessarily can make or has made) make investment shall be called 'investor' under the EVFTA. These substantial terms should be internalized into domestic law, and a Suggested Law is a good way to do that. If the latter or in both cases, the Suggested Law must cover obligations of Vietnam government to the ICS, particularly the commitments to the legal validity of the ICS awards that hold in Vietnam. Once being ratified by Vietnam National Assembly, this Suggested Law will administer the investor-State dispute relations between EU investors and Vietnam government and replace all specialized legislations for EU's investors heretofore. The WTO's Report Review"1s proposed that the Suggested Law on implementing the EVFTA on Investment should be regarded as an Omnibus Bill and at a Law-level document due to its nature of covering of a number of diverse regulations simultaneously. ${ }^{114}$

\footnotetext{
${ }^{112}$ Article 3, Law on Investment (Law No.67/2014/QH13)

${ }^{113}$ VCCI (n 95)

${ }^{114}$ For the reasons, see VCCI report (n 95)
} 


\section{Issues in respect to compliance with the NYC}

During the first five years after the entry into force of the Agreement, the recognition and enforcement of foreign arbitral awards in Vietnam shall be in accordance with the NYC but local courts are in charge of the application and authorized to review an award given by the ICS. They shall look at procedural issues and other grounds for rejection of application provided by domestic laws. Therefore, in this period, it is important to direct Vietnam's implementation towards more compatible to the NYC. Currently, there are two fundamental issues that need to be addressed promptly to make Vietnam's compliance more in line with the NYC as well as international principles, they are about the principles of law as ground of rejection an award; and the burden of proof.

At the moment, Vietnam is not specifying what their principles of law are and the interpretation they give in Resolution 01 is not clear enough. Vietnam should not continue to keep this provision for a ground of rejection without any adjustment in the future. It is advisable that Vietnam should introduce a by-law document that replaces the Resolution 01 providing that the fundamentals of law in the LCA are interpreted as fundamentals of public policy. Principles of public policy often underpin the operation of legal system in a country. It will administer the commitment of a nation to recognize and give effect to a foreign law (or in this case, a foreign arbitral award) in appropriate circumstances and govern the exceptions in which that foreign law is perceived to be injurious or harmful to public interest. In fact, these fundamentals are known under various names but with the same nature such as "public policy" or "policy of the law" in common law countries, or "ordre public", "statutory prohibition" or "kojo ryozoku" in civil law countries, ${ }^{115}$ but all of which are basically the exclusions of prohibitions to law and social moral. Given that the NYC and the Model Law

\footnotetext{
${ }^{115}$ Kent Murphy, The Traditional View of Public Policy and Ordre Public in Private International Law, 11 GA. J. INT'L \& COMP. L. 591 (1981) http://digitalcommons.law.uga.edu/gjicl/vol11/iss3/9/
} 
both use the term "public policy"; Vietnam should consider adjusting to approach in the same way.

The second issue is the Government need to assure that the Courts' practice of burden of proof will be consistent with the EVFTA. In case of application for rejection from the award debtor, Vietnamese courts should only impose the obligation of providing evidence on the one who raises the objection; and it is not the responsibility of the debtor to explain why that objection is invalid. This correction could be included in the same by-law document on guiding the implementation the enforcement of arbitral awards.

\section{Comprehensive legal review:}

Beyond fixing the two points above, Vietnamese government should continue conducting a comprehensive compatibility review of its legal framework as soon as possible far in advance the Agreement takes effect. Until now none of such wide-scope review is known of. This comprehensive legal review not only helps prepare for the EVFTA mechanism but also aims to calculate all advisability of a future single international mechanism, which Vietnam has committed in the EVFTA to establish together with the EU and other partners in the.

Areas of law that need to be revised is those that are relevant to the recognition and enforcement of awards issued by the ICS, as followed.

- the LCA 2010 and its implementing legal texts - in order to study the ICS mechanism compared to domestic arbitration activities in Vietnam.

- Laws on civil procedures including the Civil Code 2015, the Civil Procedural Code 2004, the Law on Execution of civil judgment 2008 - in order to examine the enforcement of foreign arbitral awards practice.

- Law on Investment and its implementing regulations - in order to revise the nature of dispute that has arbitrability. 
This thorough revision will help Vietnam government grasp the nature of the ICS firmly, knowing what contents need to be modified and decide which form of such modification should take (i.e. whether it is an amendment law, a by-law document e.g. a Resolution, a Decree, a Circular guiding the implementation of the agreement).

This process must be accelerated because even when Vietnam has determined the formality of revision, it still takes time for such legal document comes into effect. Meanwhile, Vietnam only has five years after the entry into force of the EVFTA, which is expected to be in 2018, to prepare for the complete application of the ICS. Whichever kind of amendment or Suggested Law is, there is definitely a need to appoint specifically which authority is responsible for implementing that amend rules.

Finally, after revising legal framework to make it compatible to application for the EU investors, Vietnam should also consider some certain adjustment for its domestic investors but must be in accordance with the MFN and NT commitments under all circumstances. Critics show that ISDS in BITs is silent on human rights - an integrated factor in investment dispute resolution ${ }^{116}$. For now, ISDS just stopped at looking at human rights as due process rights or procedural fairness, rather than having a right-based approach - "the integration of human rights as an authoritative legal regime consisting of legally enforceable entitlements" ${ }^{\prime 17}$, while investors are actively and strategically engaging human rights argumentation into their claims directly or indirectly. For example, Biloune, a Syrian investor, based his claim for human rights violation, including arrest, detention and deportation, besides contractual

\footnotetext{
${ }^{116}$ Vivian Kube and Ernst-Ulrich Petersmann, European University Institute, Working Papers Law 2016/02 Department of Law, Human rights law and international investment arbitration, ISSN 17256739

${ }^{117}$ Ibid
} 
breaches of an agreement between him and Ghana government ${ }^{118}$, or investor Rompetrol claimed for due process rights alleging that they had suffered arbitrary criminal investigations and been turned into "a target of stateorchestrated harassment". 119 These examples are to show the close linkage between human rights and investment dispute. However, it is very difficult to either assess the impact of human rights argumentation, and judicial system should have a balanced approach between investor rights and human rights. Otherwise, ISDS end up prioritizing foreign investors' interests by allowing them to freely make claims against host States' regulatory measures while this privilege is not available for domestic investors.

After all, domestic investors should be taken care of as much as the EU ones, and it is completely possible that it would come to a point in the future when Vietnamese investors would demand the same privileged treatment as the EU ones. What Vietnam can do now is revising its legislation to prevent investment dispute arising from the EVFTA or arising domestically, and develop a national strategy on investment dispute prevention if necessary.

\subsection{ICSID membership pursuit}

Vietnam has five-year period for the recognition and enforcement of awards to be subject to the NYC, after that the national courts will not be able to review the final arbitral awards but recognize and enforce it as if it is a final judgement comes from their own national court. Therefore, in the near future, Vietnam can consider joining ICSID Convention Membership to facilitate its implementation of the commitments to the Investment dispute resolution under

118 Biloune and Marine Drive Complex Ltd v. Ghana Investments Centre and the Government of Ghana, Award on Jurisdiction and Liability. 27 October 1989, Award on Damages and Costs. 30 June 1990, https://www.biicl.org/files/3935 1990 biloune v ghana.pdf

119 The Rompetrol Group N.V. v. Romania, ICSID Case No. ARB/06/3, Award 6 May 2013 https://www.italaw.com/sites/default/files/case-documents/italaw1408.pdf 
the EVFTA as well as to enhance Vietnam's legal practice with other partners in respect of recognition and enforcement of foreign arbitral awards in investment dispute. Given the popularity of the ICSD fora and the fact that nearly all member states of the EU have signed and ratified the ICSID Convention (except Poland), if Vietnam becomes a member of the ICSID, the Convention can also become a solid source of binding two Parties' governments and be applicable to final awards by the ICS of EVFTA as well. Vietnam should consider taking this step within the time scheduled of five-year period since entry into force of the Agreement, or within the time schedule for adopting any Suggested Law or amendment law.

\subsection{Responsible ministries and the need of coordination}

According to the Section 4 Resolution of Investment Disputes, there are two groups of Vietnamese agencies involved in the operation of the ICS mechanism: (i) the agencies who will directly participate in the process of the investor-State dispute resolution, which includes participation in mediation, amicable settlement, mandatory consultation, and resolution proceedings of the Tribunal system. This group mainly includes members of Investment Tribunal System, Vietnam's government and especially the Ministry of Justice (MOJ); (ii) the agencies who keep working on the negotiation of the commitments under the EVFTA to establish and maintain a smooth operation of the investment court system. This second group of agencies must carry out a number of tasks to prepare for the Decisions of the Trade Committee shortly after the entry into force of the Agreement. For better compliance and implementation of the EVFTA's commitments in respect of the Investment Dispute Resolution, the recommendations are mainly discussed about this group. The tasks that the second group needs to prepare pursuant to Sub-Section 3 are listed as follows: 
$\circ$ appoint the Members of the Tribunal and the Members of the Appeal Tribunal (Article 12 para.2, Article 13 para.3)

$\circ$ determine the amount of the retainer fee and other expenses for Members of Tribunal and Appeal Tribunal and of the Presidents of the Tribunal and Appeal Tribunal (Article 12 para.14,16,17; Article 13 para.14,16,17)

$\circ$ adopt the draft working procedures of the Tribunal or Appeal Tribunal (Article 12 para.10, Article 13 para. 10)

o adopt interpretations of the agreement which shall be binding on the Tribunal and Appeal Tribunal, if any (Article 16 para. 4)

- adopt a decision stipulating that Article 3(3) of the UNCITRAL Transparency Rules applies instead of paragraph 3 of Article 20 (Transparency of Proceedings) if upon request of either Party (Article 20 para.6)

o start to plan for negotiations for a Multilateral Dispute Settlement Mechanism (Article 15)

According to the above list, the most relevant and responsible agencies of Vietnam involved in the whole operation of the ICS are: The Ministry of Justice, The Ministry of Planning and Investment, and the Department of Planning and investment under the People's Committee.

The Ministry of Justice (MOJ) belongs to the executive branch of Vietnam's government, which direct, instruct, inspect and organize the implementation of laws and regulations. The MOJ performs the state management on execution of civil judgements, judicial-administrative activities and other justice works nationwide. ${ }^{120}$

\footnotetext{
${ }^{120}$ For functions, tasks, powers and organizational structure of the Ministry of Justice of Vietnam, see Decree No. 22/2013/ND-CP dated 13 March 2013; the Ministry's official website:

http://www.moj.gov.vn/en/Pages/Introduction.aspx
} 
The Ministry of Planning and Investment is a government agency which perform the functions of state management in planning, development investment and statistics. ${ }^{121}$ The agency also has responsibility to consult the government of national socio-economic development strategies and policies, domestic and foreign investment, etc. The MPI plays a key role in the negotiation and implementation of the EVFTA investment chapter.

Another relevant agency is the Department of Planning and Investment (DPI). The DPI does not belong to the MPI but it is a specialized agency under the management of the provincial-level People's Committee which is equivalent to a ministry-level agency. In other words, each province (or centrally-run cities i.e. Hanoi, Ho Chi Minh, Da Nang, etc.) has its own People's Committee and a Department of Planning and Investment underneath. The DPI has the role to assist the People's Committees in the province to perform the functions of state management in planning and investment at local level. The People's Committees manages the organization, staffing and operation of the DPI, meanwhile the DPI is put under the guidance, inspection and testing expertise and profession of the MPI. ${ }^{122}$

Given the functions and responsibilities of these agencies and given the amount of work listed above to prepare for the Decision of the Trade Committee in the Tribunal System, coordination among these governmental agencies is highly recommended and could be indicated as below.

\footnotetext{
121 For functions, tasks, powers and organizational structure of the Ministry of Planning and Investment, see Decree No. 116/2008/ND-CP dated 14th November 2008; and the Ministry's official website:

http://www.mpi.gov.vn/en/Pages/cnnv.aspx

${ }^{122}$ For functions, tasks, powers and organizational structure of the Department of Planning and Investment, see Joint Circular No.05/2009/TTLT-BKHĐT-BNV
} 
Figure 5.1 Relevant Ministries and agency responsible and involved in the process of ICS mechanism under the EVFTA

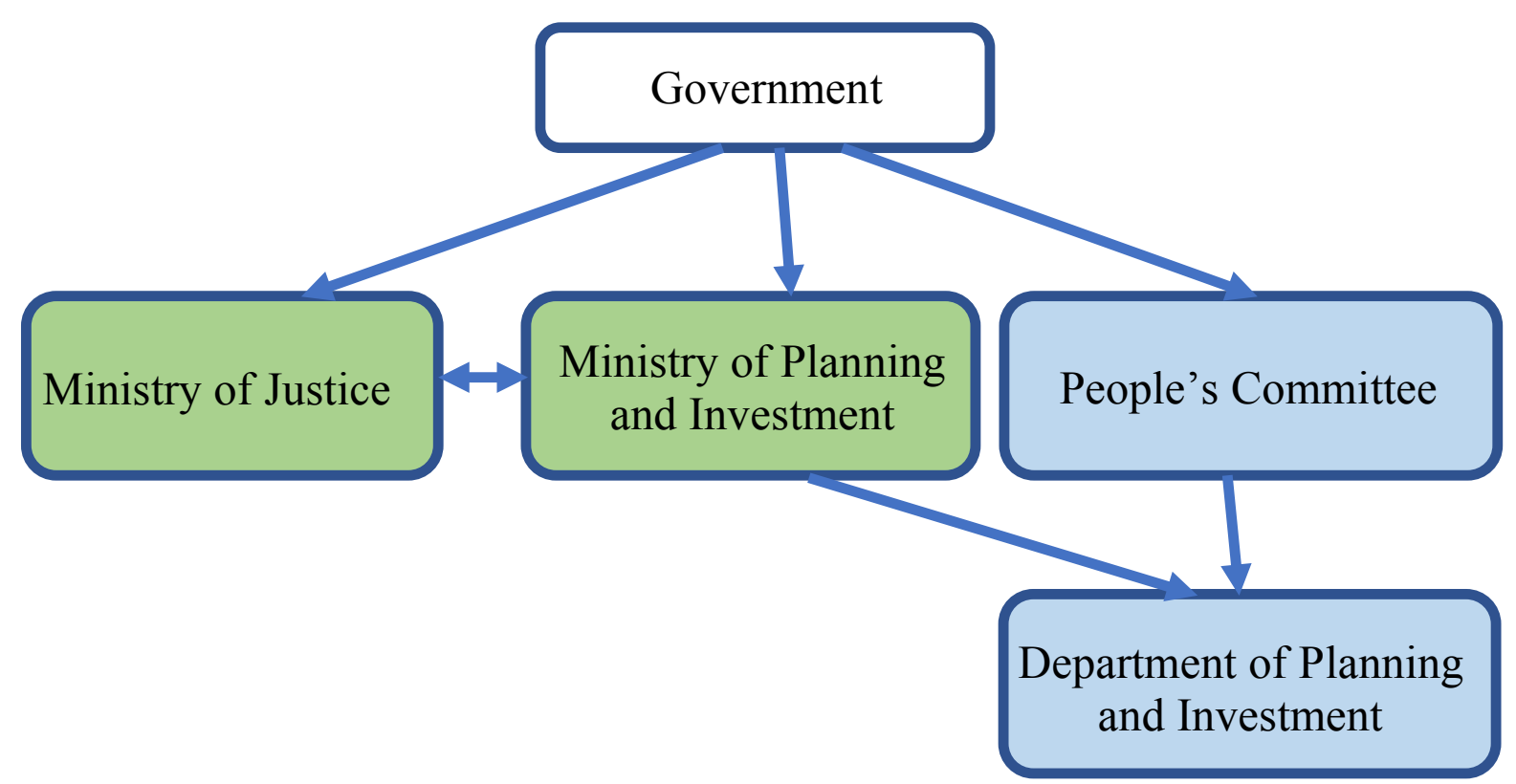

The MOJ, in cooperation with the MPI may:

$\checkmark$ Establish new or appoint a specific office within the MOJ who would play a supervisory role and responsible for keeping track on all investment disputes settled by the ICS under the EVFTA. This office would have the role to superintend the compliance of claims brought against Vietnam, in order to identify if they are in accordance with Article 7, Sub-Section 3. Moreover, the MOJ shall lead the dispute settlement process under the direction of the Government but this established office has responsibility to assist the MOJ regards administration work such as collecting and providing necessary evidence and arguments if required. Updated information and timing are very crucial in order to seek early decisions from the Tribunal to void unfounded or invalid claims. 
$\checkmark$ Secure its infrastructure and organizational structure so that the information is transferred and provided from the MOJ to the Tribunal, and between the MOJ with other relevant bodies smoothly and in a timely manner. The MOJ definitely will lead the dispute settlement process and take charge at the provision of necessary evidence or arguments, such as in case of an objection to the transparency or a need for redaction of confidential information for instance (Article 20).

Immediately start to carry out a thorough search for preeminent nominees for the Investment Tribunal System, both domestic and foreign ones. Article 12 and Article 13 of the EVFTA stipulated that these two panels are standing bodies of the investment court system whose all members are to be selected for a fixed long term (four-year period with possible once renewal), and thus the choice must be made very carefully. This process should start as soon as possible since both Parties are preparing final steps for the Agreement coming into effect. Understanding clearly about the national legal system and judicial office structure of Vietnam, the MOJ should set up further detailed requirements than those provided for in the Agreement in order to select the most suitable nominees for the Tribunal and Appeal Tribunal. Not only the criteria to nominate, Vietnam government should consider the procedure of selection (i.e. how they come to such a decision, priority ranking of criteria, whether there is any application round for candidates to apply themselves to be selected, or would it be an appointment from Government to carry out task for the state, etc.). A clear, transparent process is essential and helps boost efficiency, and it is important to bear in mind that the members of the Investment Tribunal System must be completely independent from the Government's influence both directly and indirectly. 
The MPI is an indispensable agency in this process:

$\checkmark$ The MPI should coordinate the MOJ in the process of selecting distinguished members for the ICS. MPI will assist the MOJ in respect of consultation on expertise of investment field. The MPI has in hand a network of relevant stakeholders, including governmental agencies, domestic and foreign investors in Vietnam, etc. The MPI should consult with them to understand their perspectives, know what they expect in a dispute resolution process and how their rights and benefits can be represented. From which the MPI will give consultation to the MOJ in return about what specific qualities is valued in the issue of investment disputes.

$\checkmark$ The MPI should direct the Department of Planning and Investment to supervise the investment practice at local level, so as to prevent dispute arising from investment relation. The Department of Planning and Investment is under the administration of People's Committee but still subject on the direction, inspection in respect of investment field from the MPI. It's time to establish a channel of report and review vertically between local authority and national authority. The Department along with the People's Committee should provide periodic report updating investment practice of foreign investor in the local, especially EU's investor, identifying obstacles if any. This helps supervise the investment and also the implementation of the Agreement commitments related to investment.

Furthermore, the MPI and MOJ can coordinate together in many aspects. Together the MPI and the MOJ can establish a specialized arbitration or mediation centre that solely settles investment dispute between EU investors and Vietnam government. This centre shall make efforts to resolve the disputes 
by amicable method or mediation first, before letting the claims to be brought to the ICS. Although this establishment is not mandatory under the agreement, but it is very important to maintain a productive relationship between investors and a host State. Investors and government should address their grievances at a very early stage by various ADR such as mediation, conciliation, etc. or any other problem-solving techniques to prevent their conflicts escalated into full-blown legal disputes ${ }^{123}$. The Investment Climate Unit, World Bank Group addressed the same issue, promoting the concept of "investor-State conflict management mechanisms" (CMMs) that are institutional or contractual mechanisms whose function is helping disputing parties to assess conflicts and find course of action. In an investment dispute, an unpleased investor will certainly seek consultancy from various experts about issues related to his investment (e.g. taxation, landing, contracts, investment registration, capital, banking, funding, environment, etc.). This suggested centre in Vietnam would play an important role in preventing claims and investment dispute in advance, advise EU investors so as to help resolve their grievance, encouraging them to settle disputes in amicable manner and advise them of jurisdiction, possibility of dispute, whether if EU investors should make claims at the ICS. Therefore, the officials of this centre must be the ones coming from MPI and MOJ, having expertise and understanding Vietnam's investment protection obligations and commitments under the ICS.

Finally, on the journey of the next 5 years following the entry into effect of the EVFTA, a lot of work can be improved and a lot of agencies can be involved to equip Vietnam for the implementation of the commitments to the ICS mechanism. Not only the MPI, the MOJ but also judicial system including the Supreme People's Court, the Supreme People's Procuracies, various bodies

\footnotetext{
${ }^{123}$ Global Practice on Trade and Competitiveness - Investment Climate Unit, World Bank Group. Investor-State Conflict Management: A Preliminary Sketch, E15Initiative.
} 
of the Government, the National Assembly, should join hands in the preparation. It's about time for Vietnam to have a specific national strategy about investment dispute prevention in the future and particularly focus on investment dispute arising from EVFTA.

\subsection{Database system development}

Once Vietnam has entered the FTA with the EU, it is ideal to develop a web-based system that specialized designed to serve the compliance of Parties to the investment dispute resolution of the EVFTA. This website will provide information, instruct investors the necessary steps and procedures to make a claim under the system, as well as make necessary documents available to public pursuant to the Agreement's regulation of Transparency. Such website would benefit both Vietnamese and EU investors in Vietnam, and Vietnam government. Financial resources should be exploited to make use of online infrastructure, helping reduce and simplify burden of manual management, and raise public awareness at the same time.

Vietnam can consider joining the United Nations Convention on Transparency in Treaty-based Investor-State arbitration 2014 (or so-called the Mauritius Convention on Transparency) with its Transparency Registry. By giving signature to the Mauritius Convention, Parties give their consent to apply the UNCITRAL Rules on Transparency 2014. Along with procedural rules for greater transparency, the Convention provides for a Transparency Registry ${ }^{124}$ which is a repository website for the publication of information and documents in treaty-based ISDS. Looking at the Transparency Registry, we see that Canada is the most active member. Canada uploads quite frequently and sufficiently detailed documents related to their ISDS cases, from notice of intent, posthearing brief, submission on costs, etc., to Award of the Tribunal. We can see that Canada's serious implementation of making information transparent and

\footnotetext{
${ }^{124}$ See Transparency Registry site http://www.uncitral.org/transparency-registry/registry/index.jspx
} 
available to public could explain their efficiency of governance regime, and Vietnam can follow Canada's experience by using this gate. Vietnam can collect useful information from other countries' ISDS cases accumulated in this wide platform as well.

Besides, in Vietnam the website of WTO Center and Integration by the VCCI is well content-developed, frequently updating a large number of reports in various fields of FTAs that Vietnam either already entered or in the process of negotiations. Vietnam government can consider develop further content of ICS on this platform because Vietnamese language is friendlier to Vietnamese investors, or establish their information repository on UNCTAD's Transparency Registry tool.

\subsection{Increased awareness}

Before EVFTA takes into effect, or any other new generation FTA with high commitments, or even whenever a nation has a new strategy and policy, it is important to raise awareness among public and investors to facilitate its path of progress for compliance to such commitments. In this case, Vietnam government can focus on raising public awareness to express their will to endorse the Tribunal's final awards. This could be performed by some awareness-raising activities such as broadcasting information to public, legal communities and enterprises communities about the new arbitration system. We can see that overseas there are countless articles, news over media and also research papers in the EU, the U.S and the Canada in which the public show a lot of controversial opinions and arguments about the investment tribunal system in EU's proposals, not to mention the amount of research journals conducted on the issue. This to say that the interest and concern of public about the topic is very strong, diversified and widely discussed. However, in Vietnam we do not see any news or articles that deliver the topic of the ICS in EVFTA. This odd quietness might have something to do with the Government's 
influence on limiting the negative effect of the mechanism. Specifically, it is a common fear that the ICS enable a Government to be exposed to being sue by a foreign investor, as discussed in part 2 of this paper. However, efforts in raising public awareness and making things more opened shall definitely help affirm the Vietnamese and EU investors' confidence in the fairness and effectiveness of the ICS mechanism.

For public awareness, the Government can take advantages of the website system discussed above, to introduce general contents of the ICS (what is it for, who can claimants, who can be defendants, what are valid alleged claims and procedure, etc.). The contents for this purpose should be in plain language to inform general interested public and investors.

\subsection{Capacity training and technical assistance}

The investment court put in use definitely requires further technical assistance from both parties in form of training to develop human resources' capacity in the issue. Not only staffs, officials but academics training should be encouraged. At the moment, the European Trade Policy and Investment Support Project $^{125}$ (EU-MUTRAP) in Vietnam has proved its efficiency in facilitating Vietnam's integration into the regional trading system and support EU-Vietnam trade and investment relations. Through various activities, such as workshops, conferences, training programs, etc., the support of MUTRAP does help Vietnam to meet certain standards to international. Given the complex nature of the ICS, Vietnam is absolutely in need of further technical assistance, for instance in research capacity and personnel.

\footnotetext{
${ }^{125}$ MUTRAP is the Multilateral Trade Assistance Project whose main sponsor is European Union and the executing authority and implementing agency is Ministry of Industry and Trade of Vietnam (MOIT). The purpose of the project is "to support the MOIT in facilitating sustainable international trade and investment through improved capacity for policy making, policy consultation, and the negotiation and implementation of related commitments, particularly vis-à-vis the EU"

(http://mutrap.org.vn/index.php/en/home )
} 
Technical assistance can take place in many forms. It is ideal to have technical assistance from investment law expertise from international combined with Vietnamese training program. Perhaps Vietnam should seek advice from Argentina - the most frequent respondent States or from the U.S, Netherlands the most frequent home States of claimants ${ }^{126}$, given their experienced involvement in ISDS. Moreover, external support is not enough. Sometimes international experience is not tailored to domestic needs and not suited to apply directly into domestic current practice. A combination of both foreign and domestic approach is very useful. They would play an important role in helping Vietnam's government and relevant Ministries to:

- conduct legal review;

- share lesson experiences in investment disputes resolution;

- draft our strategic plan or roadmap for investment disputes prevention;

- or implement training programs for Vietnamese officials in responsible ministries. The Government of Vietnam should encourage education and training of international law at university level or promote professional training programs for investment lawyers, judicial officials, in order to prepare for the operation of the ICS in the long run.

$* * * * * * * * * * * * * * * * * * * * * * * * * * * * * * * * * * *$

${ }^{126}$ UNCTAD, IIA Issues Note International Investment Agreements, Issue 3, November 2017, Special Update on Investor-State dispute settlement: Facts and figures http://unctad.org/en/PublicationsLibrary/diaepcb2017d7 en.pdf 


\section{BIBLIOGRAPHY}

1. Andrew Newcombe, Lluis Paradell, Law and Practice of Investment Treaties: Standards of Treatment, Kluwer Law International BV, The Netherlands Publisher 2009

2. Anh Luu, Le Thi Hanh, February 2017, Vietnam Legal Research http://www.nyulawglobal.org/globalex/Vietnam1.html\# Judicial System

3. Biloune and Marine Drive Complex Ltd v. Ghana Investments Centre and the Government of Ghana, Award on Jurisdiction and Liability. 27 October 1989, Award on Damages and Costs. 30 June 1990, https://www.biicl.org/files/3935 1990 biloune $\mathrm{v}$ ghana.pdf

4. Corinne Nguyen, Anh Duong Vu, Arbitration in Vietnam in Journal of International Arbitration, Issue 5 Volume 31 (2014) pp.675-682

5. Celeste E. Salinas Quero, Investor-State disputes at the SCC, Arbitration Institute of the SCC, Stockholm 2017

6. Council of the European Union, Joint Interpretative Instrument on the Comprehensive Economic and Trade Agreement (CETA) between Canada and the European Union and its Member States, 13541/16 Brussels 27 October 2016.

7. Damian Wnukowski, EU-Vietnam Free Trade Agreement Opportunities and Challenges for European Businesses, The Polish Institute of International Affairs Bulletin, No.5 (737), 15 January 2015.

8. Delegation of the European Union to Vietnam, Guide to the EU-Vietnam Free Trade Agreement, June 2016 available at

http://eeas.europa.eu/archives/delegations/vietnam/documents/eu vietnam/evfta guid e.pdf

9. European Commission Press Release of 29 February 2016 http://europa.eu/rapid/press-release IP-16-399 en.htm

10. Explanatory Note by the UNCITRAL Secretariat on the 1985 Model Law on International Commercial Arbitration as amended in 2006, http://www.uncitral.org/pdf/english/texts/arbitration/ml-arb/MLARBexplanatoryNote20-9-07.pdf

11. Gary Clyde Hufbauer, 'Investor-State dispute settlement', in Trans-Pacific Partnership: An assessment, Volume 104 of Policy Analyses in International Economics, Cathleen Cimino-Isaacs and Jeffrey J.Schott, July 2016, Peterson Institute for International Economics.

12. Gaukrodger, D. and K. Gordon (2012), Investor-State Dispute Settlement: A Scoping Paper for the Investment Policy Community, OECD Working Papers on International Investment, 2012/03, OECD Publishing. http://dx.doi.org/10.1787/5k46b1r85j6f-en.

13. Global Practice on Trade and Competitiveness - Investment Climate Unit, World Bank Group. Investor-State Conflict Management: A Preliminary Sketch.

E15Initiative. Geneva: International Centre for Trade and Sustainable Development (ICTSD) and World Economic Forum, 2015. www.e15initiative.org/

14. Gus Van Harten, A case for an International Investment Court, online proceedings Working Paper No.22/08, Inaugural Conference of Society of International Economic Law, Geneva, July 15-17 2008, available at http://www.ssrn.com/link/SIEL- 
Inaugural- Conference.html

15. Hannes Lenk, An investment Court System for the new generation of EU trade and investment agreements: A discussion of the free trade agreement with Vietnam and the comprehensive economic and trade agreement with Canada, European Papers Vol.1, 2016, No 2 pp.665-667.

16. Hederer, Christian, Third-Party Funding in International Investment Arbitration Economic Analysis and Regulatory Options (December 2016). Available at

SSRN: https://ssrn.com/abstract $=2952488$

17. ICSID 2016 Annual Report

18. ICSID Caseload - Statistics, Issue 2017 - 1

19. ICSID Caseload - Statistics, Issue $2017-2$

20. International Council for Commercial Arbitration (ICCA)- Queen Mary University of London Task Force, Internal Working draft 1st September 2017, Draft Report for Public Discussion on Third-Party Funding in international Arbitration. http://www.arbitrationicca.org/media/9/75899457734281/submission_version for public comment draft.p $\underline{\mathrm{df}}$

21. Introduction CIArb London Centenary Principles http://www.ciarb.org/docs/defaultsource/ciarbdocuments/london/the-principles.pdf?sfvrsn=4

22. Kent Murphy, The Traditional View of Public Policy and Ordre Public in Private International Law, 11 GA. J. INT'L \& COMP. L. 591 (1981) http://digitalcommons.law.uga.edu/gjicl/vol11/iss3/9/

23. Laura Puccio, Investment rules in trade agreements: Developments and issues in light of the TTIP debate, European Parliament Research Service (ERPS), September 2015, PE 568.333 ISBN 978-92-823-7552-5

24. Lan Ah Nguyen, Hao Duy Phan and Jessye Freeman, International and ASEAN Law in the ASEAN 10 National Jurisdictions: The Reception of International Law in the Legal System of Vietnam, Centre for International Law (CIL) Working Paper.

25. https://cil.nus.edu.sg/wp-content/uploads/2016/08/SD ES-ASEAN-10-Vietnamstudy.pdf

26. Morris S. Rosenthal, Arbitration in the Settlement of International Trade Disputes, 11 Law and Contemporary Problems 808-834 (Fall 1946)

Available at: https://scholarship.law.duke.edu/lcp/vol11/iss4/13

27. Nguyen Manh Dzung, Dang Vu Minh Ha, Vietnam Arbitration Guide, 2014, International Bar Association, available at https://www.ibanet.org/Article/NewDetail.aspx?ArticleUid=a646cf32-0ad8-4666$\underline{876 \mathrm{~b}-\mathrm{c} 3 \mathrm{~d} 045028 \mathrm{e} 64}$

28. Nguyen Thanh Tuan, Trinh Vinh Binh vs. Vietnam http://nghiencuuquocte.org/2017/09/04/vu-kien-trinh-vinh-binh-vs-chinh-phu-vietnam/ (Vietnamese)

29. OECD (2004), Fair and Equitable Treatment Standard in International Investment Law, OECD Working Papers on International Investment, 2004/03, OECD Publishing. http://dx.doi.org/10.1787/675702255435

30. OECD (2012) Investment Division, Directorate for Financial and Enterprise Affairs, Investor-State Dispute Settlement - Public Consultation: 16 May - 9 July 2012

31. OECD (2012) Dispute settlement provisions in international investment agreements: A large sample survey http://www.oecd.org/investment/internationalinvestmentagreements/50291678.pdf 
32. Paparinskis, M., \& Howley, J. (2015). Article 5. Submission by a non-disputing Party to the treaty. In M. Wong \& R. Hadgett (Authors) \& D. Euler, M. Gehring, \& M. Scherer (Eds.), Transparency in International Investment Arbitration: A Guide to the UNCITRAL Rules on Transparency in Treaty-Based Investor-State Arbitration (pp. 196-226). Cambridge: Cambridge University Press

33. Piero Bernardini, 2009, ICSID versus Non-ICSID Investment Treaty Arbitration, Available at http://www.arbitrationicca.org/media/4/30213278230103/media012970223709030bernardini icsid-vs-nonicsid-investent.pdf

34. Premium Nafta Products Limited and others Vs. Fili Shipping Company Limited and others, Opinions of the Lords of Appeal for Judgement in the cause, Session 2006-07, [2007] UKHL 40

35. PricewaterhouseCoopers (PwC) and Queen Mary, University of London, '2015 International Arbitration: Improvements and innovations in International Arbitration'.

36. Rudolf Dolzer and Christoph Schreuer, Principles of international investment law, 2008 Oxford University Press.

37. SCC Statistics 2016: http://www.sccinstitute.com/statistics/

38. Scott Miller, Gregory N.Hicks, Investor-State Dispute Settlement: A Reality check, A Report of the CSIS Scholl Chair in International Business, Center for Strategic \& International Studies (CSIS), January 2015.

39. The Rompetrol Group N.V. v. Romania, ICSID Case No. ARB/06/3, Award 6 May 2013

https://www.italaw.com/sites/default/files/case-documents/italaw1408.pdf

40. UNCTAD, IIA Issues Note International Investment Agreements, Issue 1, May 2017, Investor-State dispute settlement: Review of developments in 2016.

41. UNCTAD, IIA Issues Note International Investment Agreements, Issue 3, November 2017, Special Update on Investor-State dispute settlement: Facts and figures http://unctad.org/en/PublicationsLibrary/diaepcb2017d7 en.pdf

42. UNCTAD Investment Policy Hub http://investmentpolicyhub.unctad.org/ISDS/

43. UNCTAD World Investment Report 2017, Investment and Digital economy: Key messages and overview.

44. Vietnam Chamber of Commerce and Industry (VCCI), July 2016, Report Review Vietnam's legal framework against commitments under the EVFTA on investment http://wtocenter.vn/publication/reviewing-vietnamese-laws-and-regulations-againstevfta-commitments-investment

45. Vivian Kube and Ernst-Ulrich Petersmann, European University Institute, Working Papers Law 2016/02 Department of Law, Human rights law and international investment arbitration, ISSN 1725-6739

46. World Economic Forum, Global Competitiveness Report, 2016-2017;

47. World Economic Forum, Global Competitiveness Report, 2017-2018 